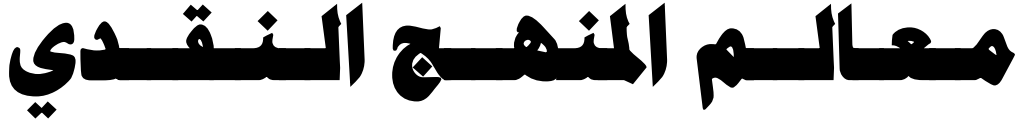

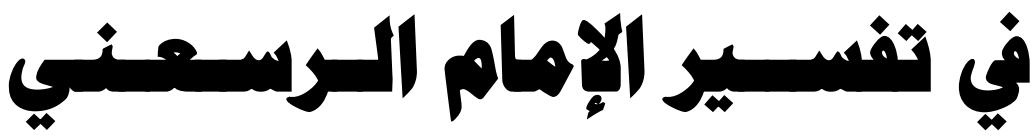

\section{- إعداد}

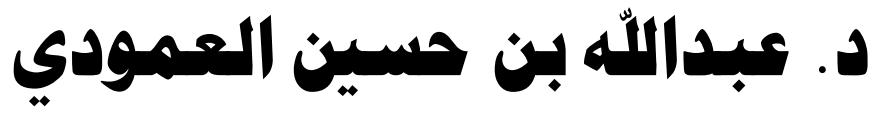

أستاذ التفسير وعلوم القرآن المساعد بجامعة تبوك

$$
\text { من • PVA }
$$


ryt 


\section{ملخص البحث \\ ملخص البحث}

يتناول هذا البحث موضوعًا من أهم موضوعات أصول التفسير وهو نقد التفسير؛ إذ بـ تتمايز الأقوال المقبولة من المردودة، ويتبين المعنى الصحيح للآيات الكريمة وفق الأسس والأصول العلمية. ويهدف هذا البحث إلم الكشف عن معالم المنهج النقدي في تفسير "ارموز الكنوز

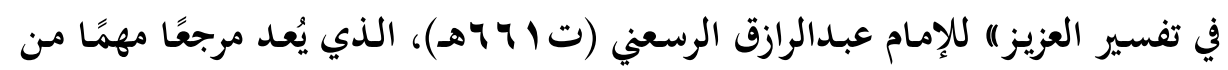
مراجع علم التفسير، ومؤلفه من أهل الرسوخ والتحقيق والتمكن العلمي، وقد اجتهد في تحير تفسيره وتدقيقه بصورة ظاهرة، وكان الجانب النقدي أحد الجوانب التي تميز بها؛ لذا أردت مـن خحلال هذه الدراسـة بيـان الأسـاليب التي سـار عليها في نقده، وإيضـاح صـيغ النــد التي استخدمها، وإبراز الأسـس التي استتند إليها في نقـده، والبجالات التي تناولها بالنقد في ثنايا تفسيره، وفي الحاتمة ذكرت أهم نتائج البحث وتوصياته. كلمات مفتاحية: منهج، نقل، تفسير، رسعني.

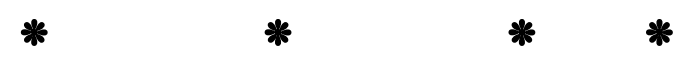




\section{بسم الله الرمن الرحيم \\ المقدمة}

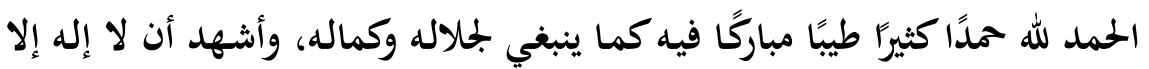

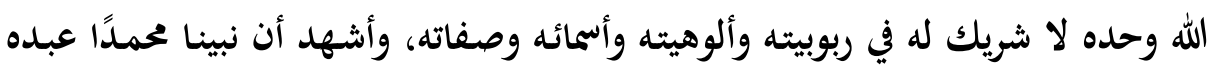
ورسوله خيرته من خلقه وصفوة رسله وأنبيائه، صلى الله وسلم وبارك عليه، وعلى آلى آله وأصحابه، ومن تبعهم بإحسانٍ إلم يوم لقائه. أمَّا بعد: فلقد حظي ومن تبعهم بإحسال إلى يوم التفسير بعناية أهـل العلم العناية الكبيرة؛ لتعلقه بأصل

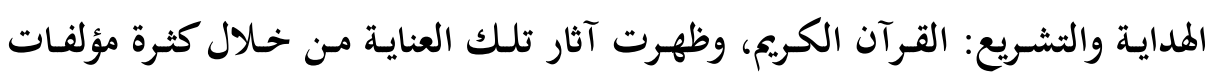
التفسير المطبوعة والمخطوطة، وتعددت طرائق العلماء واتجاهاتم في تفسيرهم للقرآن، فمنهم من اعتنى بجانب الرواية دون الاهتمام بالدراية، فأورد الروايات وذكر الأقوال

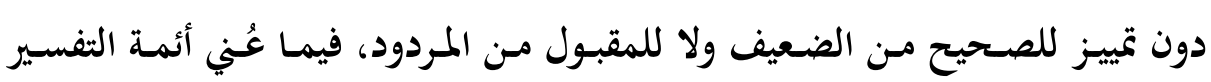

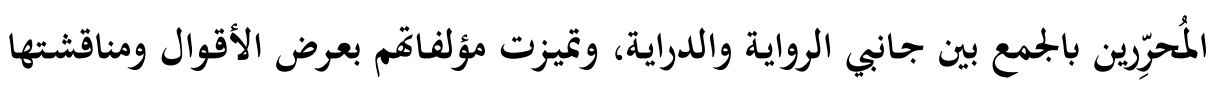

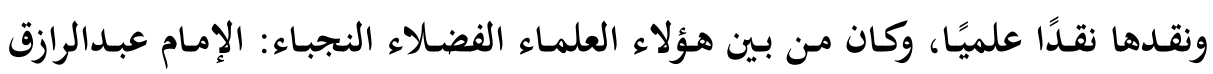

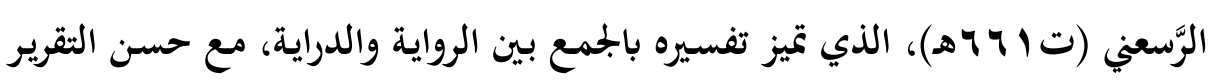
وجودة التحرير، والمناقشة والنقد.

ولأهمية جانب النقد وأثره الكبير في علم التفسير، وللقيمة العلمية التي تميز بهـا تفسير الإمام الرسعني؛ عزمت -مستعينًا بالله تعالمى - على دراسة معالم المنهج النقدي في تفسيره، وذلك ببيان أساليبه التي سار عليها، وإيضاح صيغ النقد التي استخدمها، وإبراز الأسس التي استند إليها في نقده، والمجالات التي تناولها بالنقد مقرونة بالمثال.

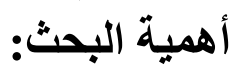

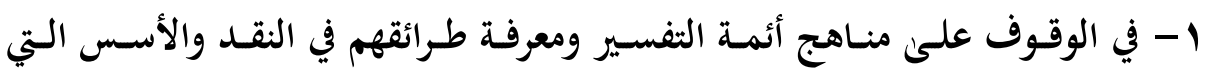

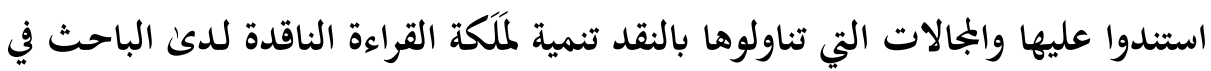
علم التفسير، وبـذلك يكتسب طالب العلم قدرة على فهم أقوال المفسرين وسبرها 
Y- القيمة العلمية لتفسير (رموز الكنوز في تفسير الكتاب العزيز)،، كما سيأتي الإشارة

إليها.

ب- أن الإمـام الرسعني مـن أئمسة أهـل السـنة والجماعة الذين كـان لهم جهـد واضـح في تقرير اعتقاد سلف الأمة الصالح والرد على مخالفيهم بالدليل والتعليل.

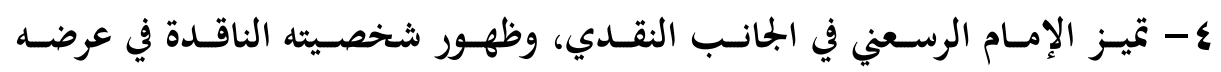
ومناقشته.

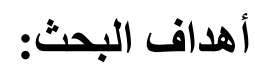
1- بيان الأساليب التي سار عليها الإمام الرسعني في نقده. r - إيضاح صيغ النقد التي استخدمها. ب- إبراز أسس النقد التي استند إليها. ع - معرفة المجالات التي تناولها بالنقد.

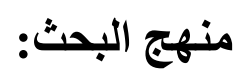

اقتضت طبيعة البحث أن أسلك في إعداده المنهج الاستقرائي والوصفي، وفق ما

أولاً: التمهيد، وتضمن دراسة موجزة للتعريف بالإمام الرسعني، وبتفسيره "ارموز الكنوز في تفسير الكتاب العزيز) .

ثانيًا: ترتيب الأساليب التي سار عليها الإمام الرسعني في نقده، والصيغ التي استخدمها، والأسس التي استند إليها في نقده، والججالات التي تناولها بالنقد بحسب الأبسام الأكثر ورودًا فالأقل. ثالثًا: اكتفيت بمثالٍ واحد لكل عنصر من عناصر البحث، مع الإشارة إلمى بقية الأمثلة.

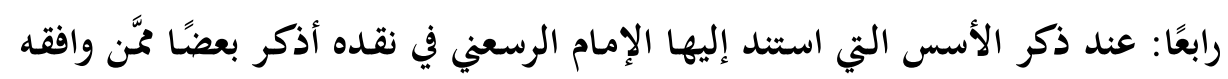
من أئمة التفسير في الاحتجاج بمذا الأساس والاعتماد عليه في الترجيح والنقد. خطة البحث: من أنة الثفير يشتمل البحث على الآتي: 
المقدمة: وتتضمن بيان أهمية موضوع البحث، وأهدافه، ومنهجه، وخطته. التمهيد: ويتضمن التعريف بالإمام الرسعني وبتفسيره. الفصل الأول: أساليب النقد وصيغه عند الرسعني، وفيه مبحثان: المبحث الأول: أساليب النقد عند الرسعني. المبحث الثالي: صيغ النقد عند الرسعني. الفصل الثاني: أسس النقد ومجالاته عند الرسعني، وفيه مبحثان: المبحث الأول: أسس النقد عند الرسعني.

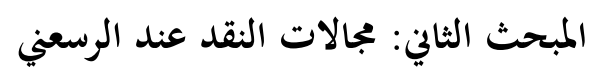

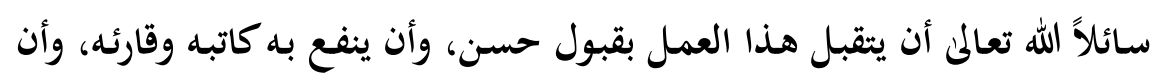

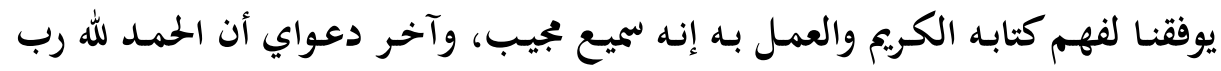
العالمين. 


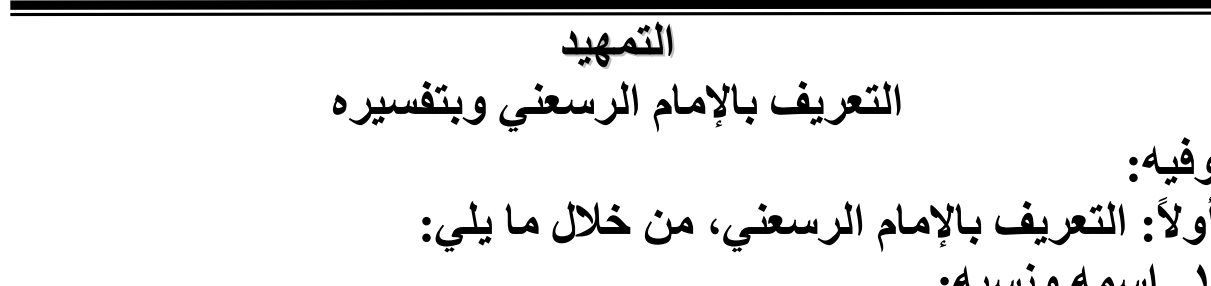

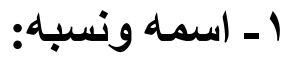

عبدالرازق بن رزق الله بن أبي بكر بن خلف بن أبي الهيجاء الرسعني (1)، يُكني بأبي

محمد، ويُلَّقب بعز الدين (r).

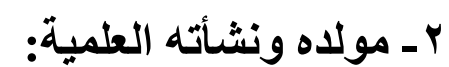

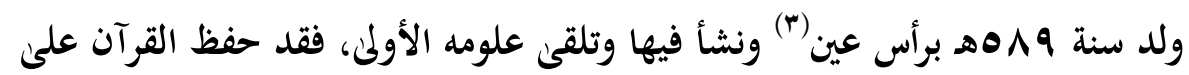

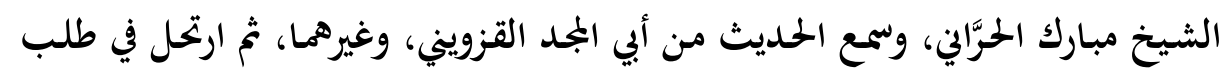

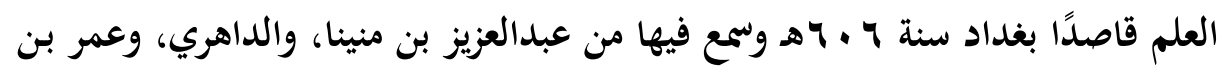

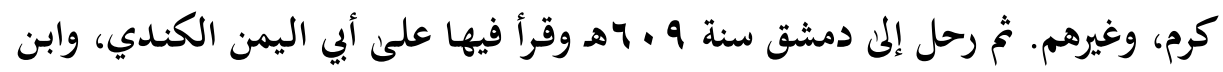

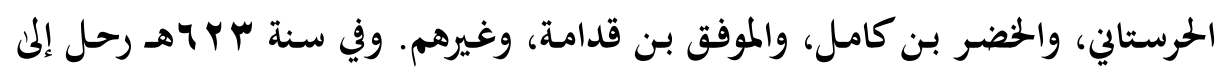

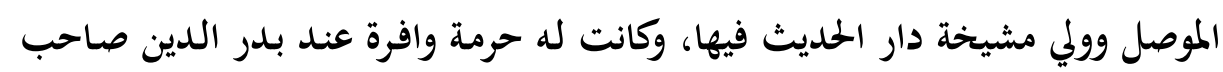

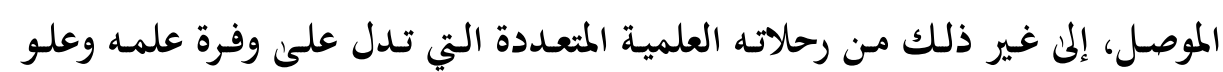
همته (\&)

(1) نسبةً إلى رأس عين، وهي مدينة كبيرة مشهورة من مدن الجزيرة بين حرَّان ونصيبين ودُنيسر، وتقع حاليًا

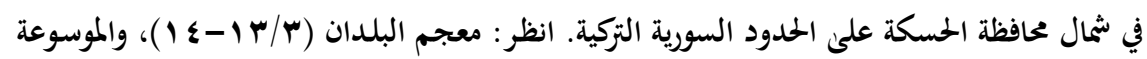
الحرة (ويكيبيديا) على شبكة الإنترنت.

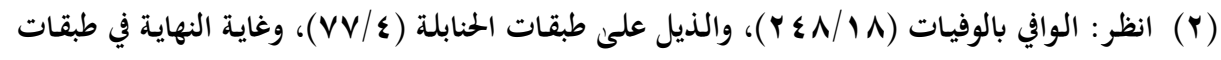

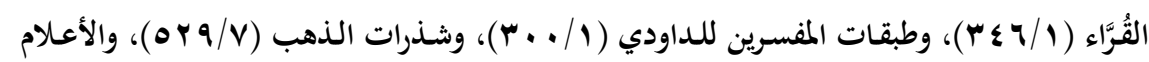

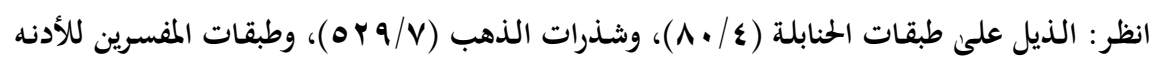

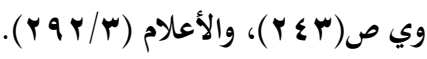

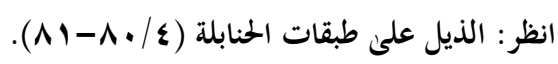




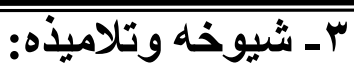

تتلمذ على عددٍ من أهل العلم المُبرزين، وكان لرحلاته العلمية المثعددة أثرها في كثرة

شيوخه، فمن هؤلاء العلماء الذين أخذ عنهم:

1- عبد العزيز بن معالي بن غنيمة بن الحسن الأشناين المعروف بابن مَنِينا، أبو محمد،

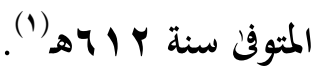

ץ- زيد بن الحسن بن زيد بن الحسن الكندي البغدادي، أبو اليمن، تاج الدين، شيخ

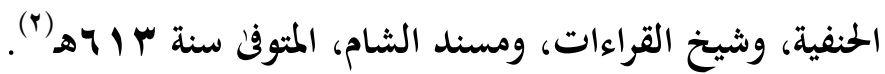

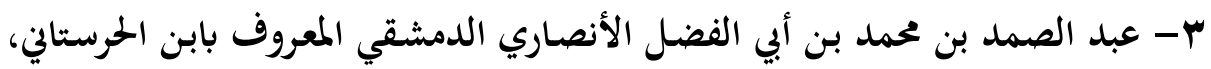

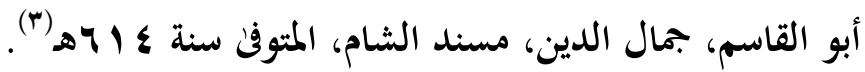

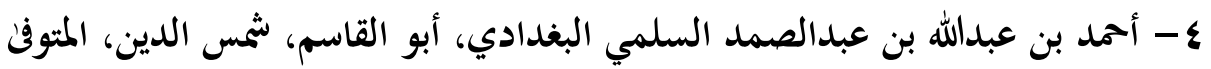

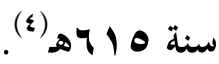
ه- عبد الله بن الحسين بن أبي البقاء العُكُبري، أبو البقاء، محب الدين، الإمام، العلاًّمة،

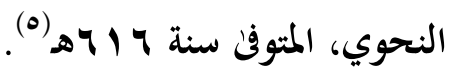
ج- عبد الله بن أحمد بن محمد بن قدامة المقدسي الجمَّاعيلي، أبو محمد، موفق الدين،

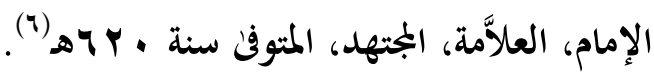
وممَّن تتلمذ عليه:

1- المبارك بن أبي بكر بن حمدان الموصلي، أبو البركات، كمال الدين، المعروف بابن

الشعار، المتوفن سنة ع ه هـ (1).

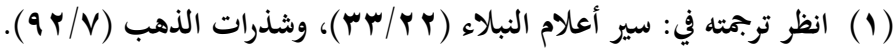

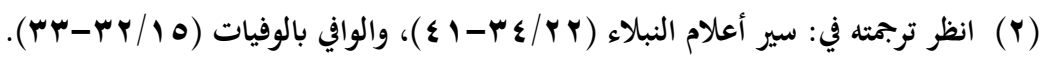

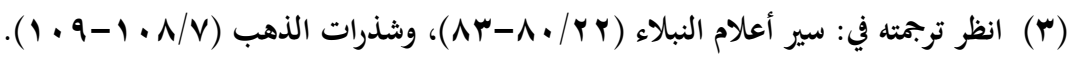

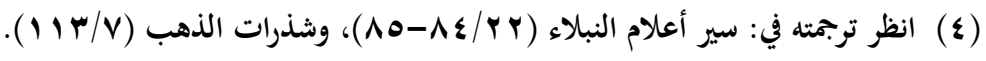

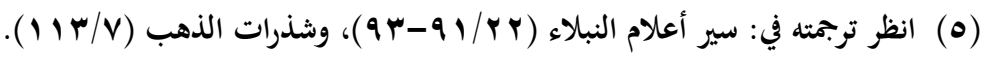

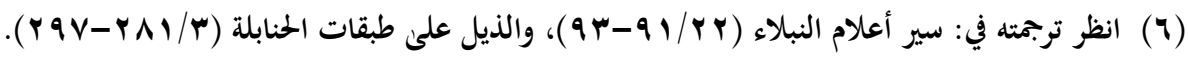




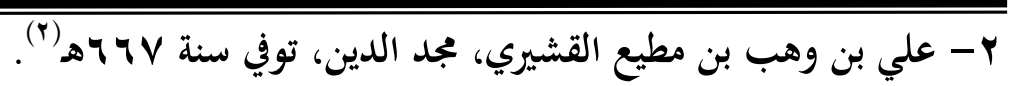

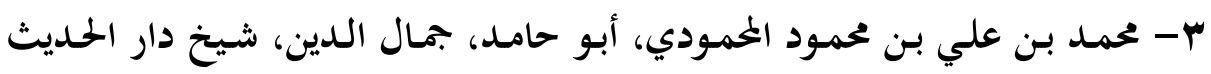

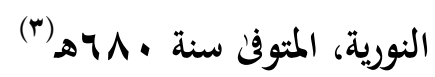

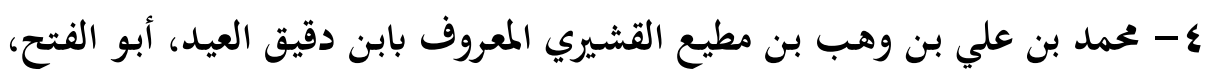

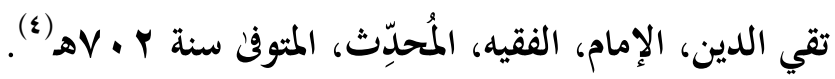

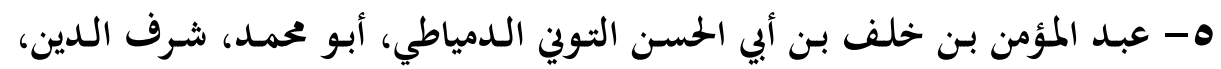

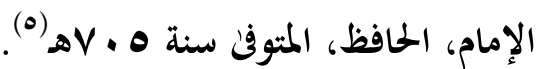

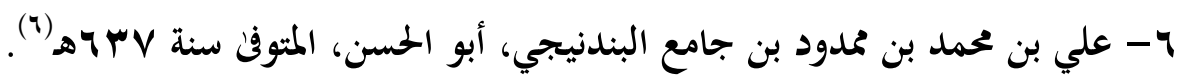

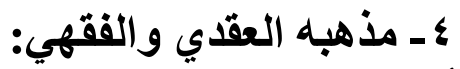

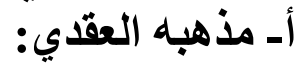

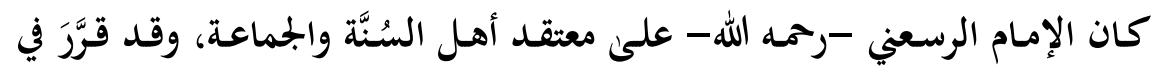

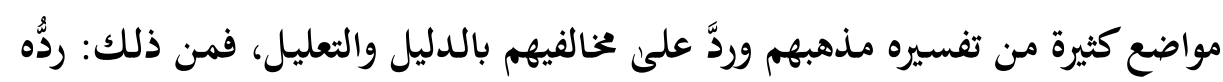

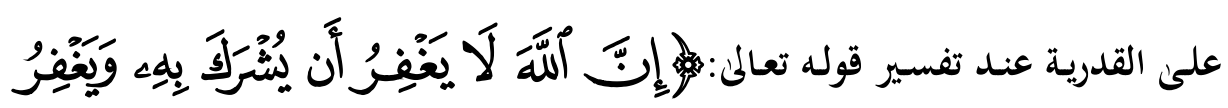

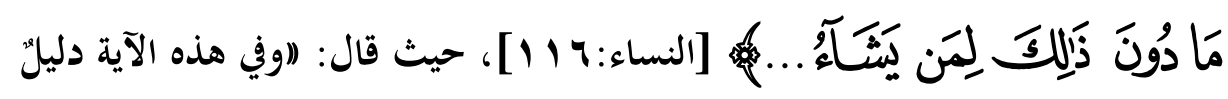

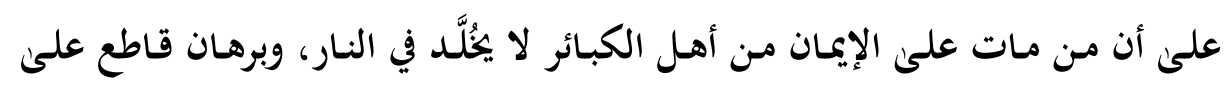

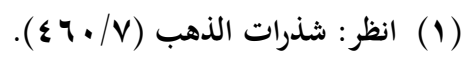

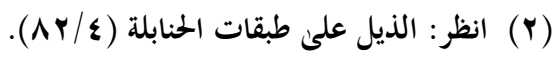

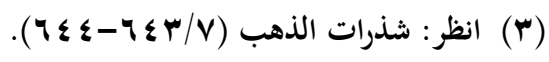

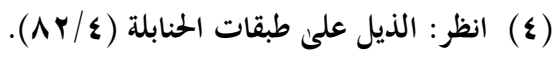

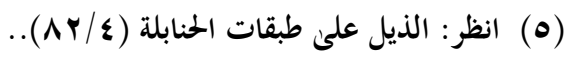


بطلالن مـا انتحلـه القَدَريـة مـن قـولم: لا يجـوز أن يغفــ الله الكبـيرة، ولا أن يعفـو عن (المعاصي") (1)

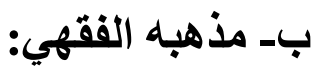
وأََّّا في الفروع فقد كان حنبلي المذهب وهذا ما نصَّ عليه أهل العلم الذين ترجموا له (ז)، وفي تفسـيره مواضـع متعـددة تـدل على ذلك، منهـا: مـا جـاء عنــ تفسـير قوله

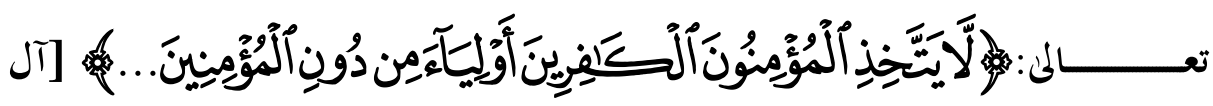

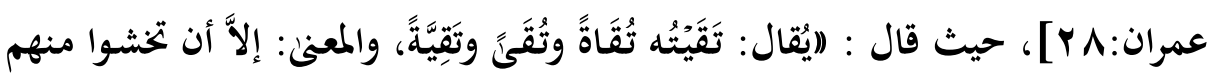
أمرًا، تحتـاجون معـه إلمى التَّقِيَّة، فتصـانعوهم بألسـنتكم، وتُفــارقوهم بقلـوبكم وأعمـالكم،

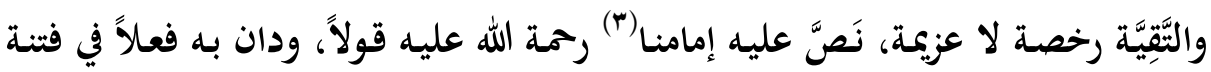

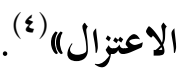
ه - مكاتته العلمبة: تبوأ الإمـام الرسعني مكانة رفيعة بين علمـاء عصره، وقـد أثنن عليه من ترجموا له، وشهدوا له بالفضل والعلم، فهذا الإمام الذهبي يقول في ترجته: (اوكان شيخ الجزيرة في زمانه علمًا وفضالًا وجلالة)|"(•).

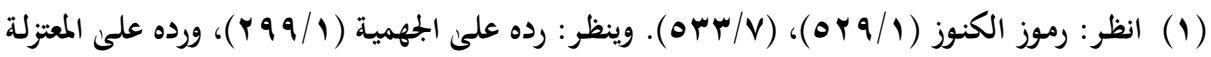

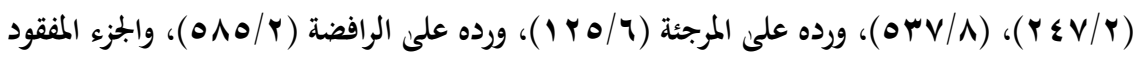
ص)

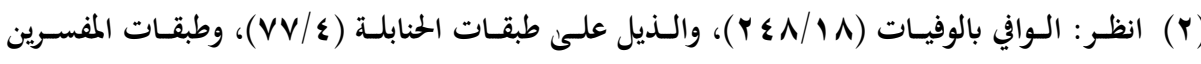

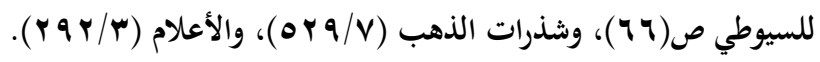

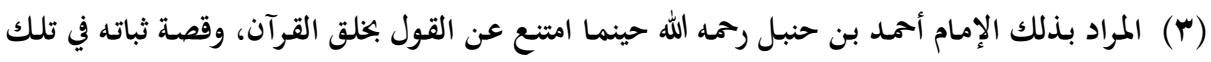
الفتنة مشهورة ومدونة في كتب التراجم والسير.

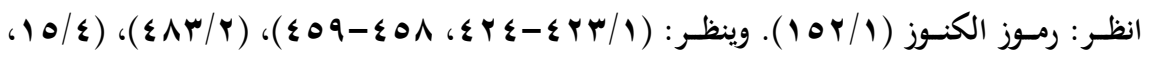

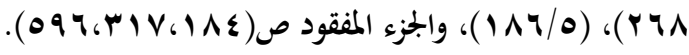

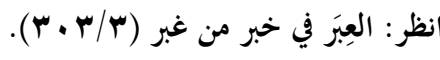




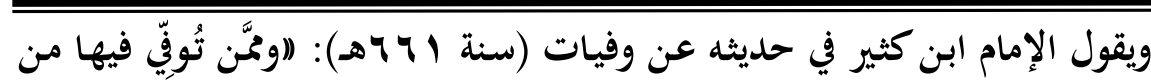
الأعيان: عبدالرزاق بن رزق الله بن أبي بكر بن خلف، عز الدين، أبو محمد الرَّسعني،

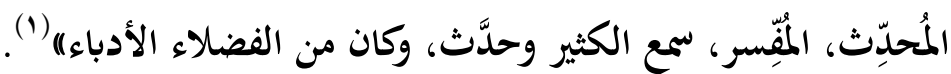

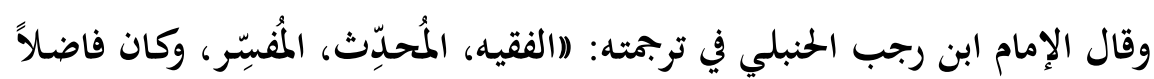
في فنولٍ من العلم والأدب، ذا فصاحةٍ وحسن عبارة، وله نظمٌ حسن)" (؟).

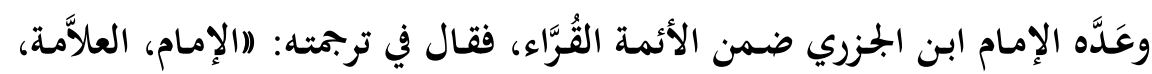

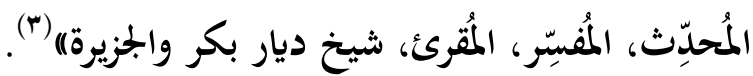

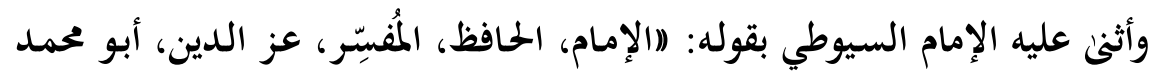

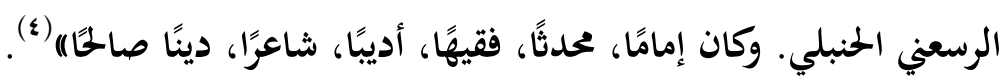

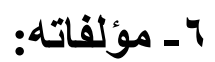
ترك الإمام الرسعني مصنفات في فنون متنوعة تدل على غزارة علمه وسعة اطلاعه، وفيما يلي ذكر لمؤلفاته التي أشارت إليها كتب التراجم: 1- تفسير رموز الكنوز في تفسير الكتاب العزيز (ه).

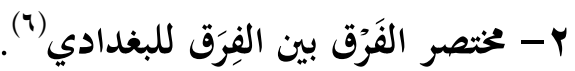
ب- دُرَّة القارئ في الفرق بين الضاد والظاء (1).

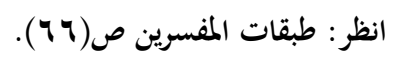

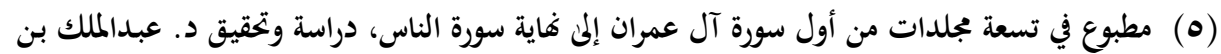

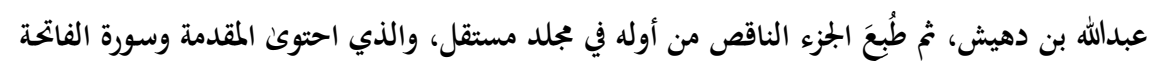

$$
\text { وسورة البقرة وصدر سورة آل عمران. }
$$

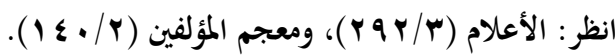


ع - المنزع الصافي من المين في مصرع الإمام الثهيد أبي عبداله الحسين المعروف بمصرع

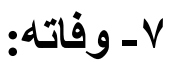

بعد حياة حافلة بالتعلم والتعليم والتصنيف والتأليف توفي الإمام الرسعني -رحمه

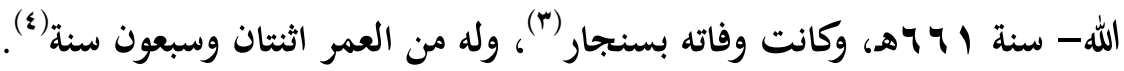

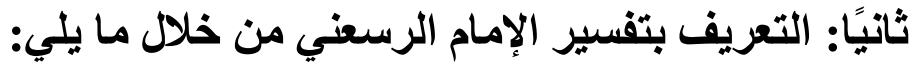
1 - منهجه:

أبان المؤلف عن منهجه الذي سلكه في تفسيره في مقدمة كتابه بقوله: (ا اجتهدتُ في تلخيصه من التكرار، وحرصتُ على تخليصه من الأكدار، وحميته من حكاية الأقوال

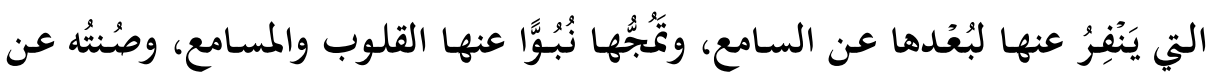

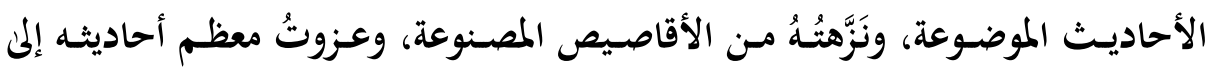

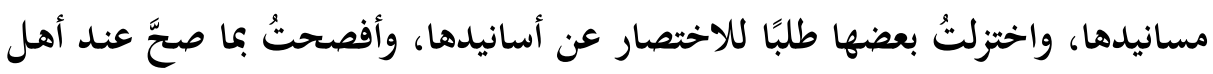

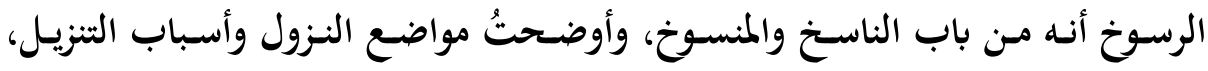

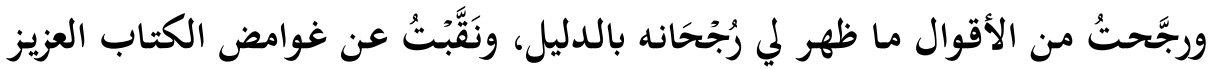
بمبلغ علمي، وكشفتُ عن أسراره بحسب فهمي، وفَصَّلتُ مجمل الفقه عند آياته ببيان

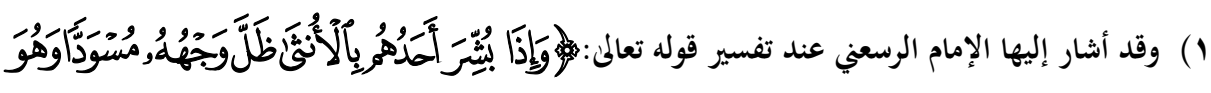

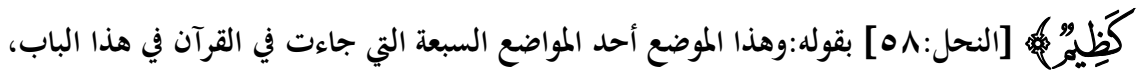

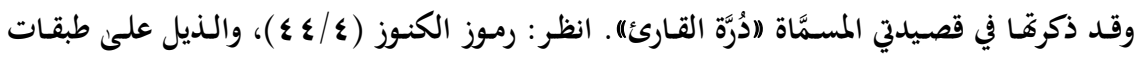

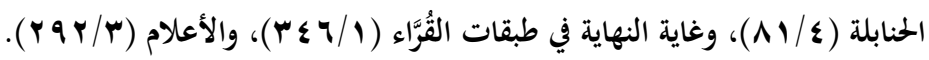

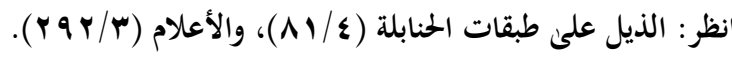

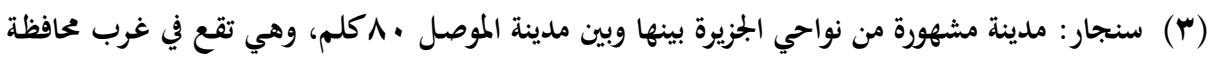

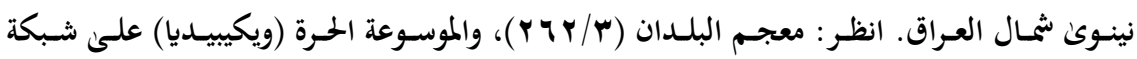
الانتزنت.

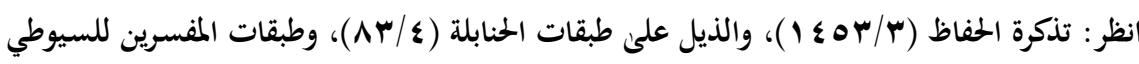

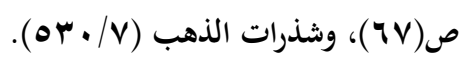




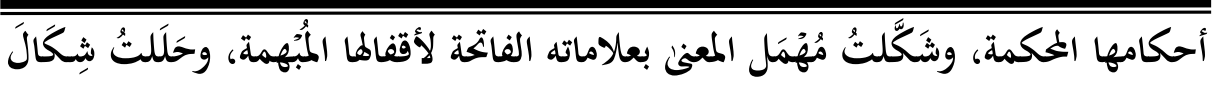

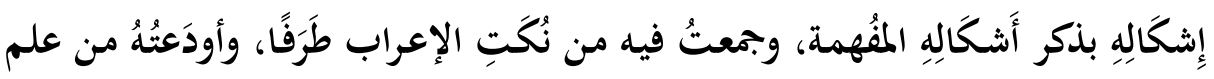

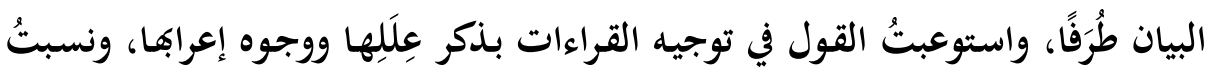

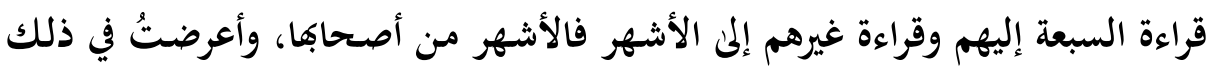

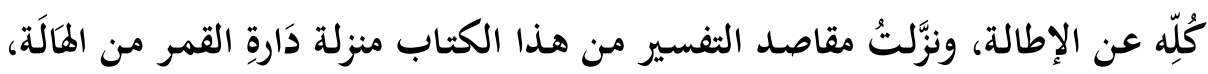

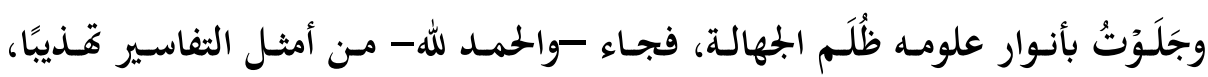

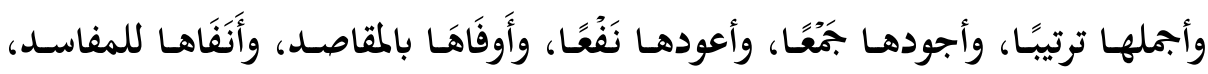

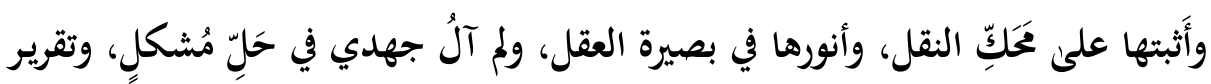

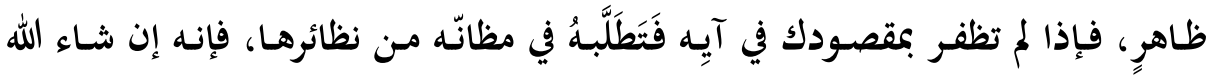

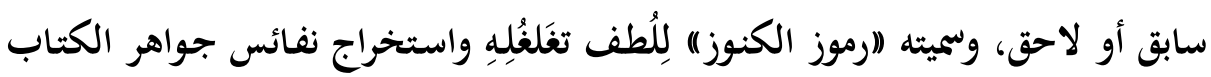

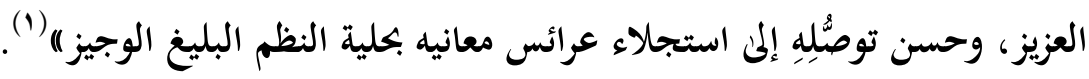
ب ـ قيمته العلمية: نال تفسـير الإمـام الرسعني ثنـاء أهـل العلـم تمَّن تـرجم لـه، فهـذا الإمـام الـذهبي

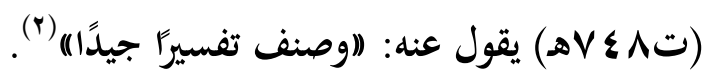
وقال ابن رجـب الحنبلي (ته9 9هـ): (اوصَنَّفَ تفسيرًا حسنًا في أربع مجلدات ضخمة سمَّاه ((رموز الكنوز))، وفيه فوائد حسنة، ويروي فيه الأحاديث بإسناده، وله في تفسيره مناقشات مع الزخشري وغيره في العربية وغيرها) (r)". وقال السيوطي (ت | | 9هـ): (اوصَنَّفَ تفسيرًا حسنًا يروي فيه بأسانيده)|"(1) .

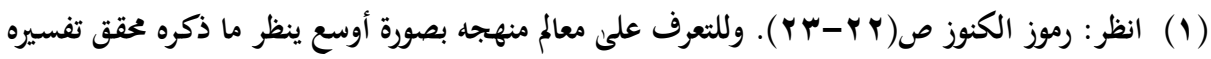

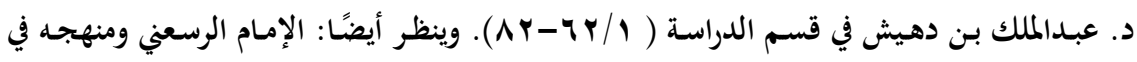

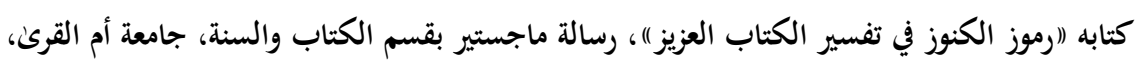
للباحثة: أحلام بنت مصطفى الحريي.

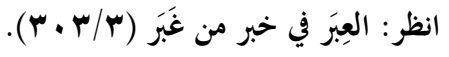




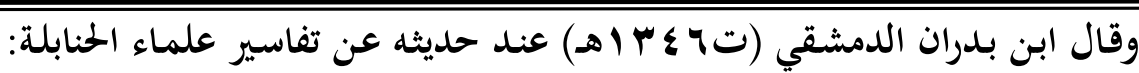

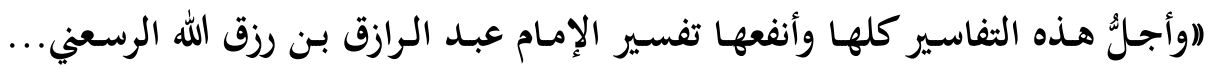

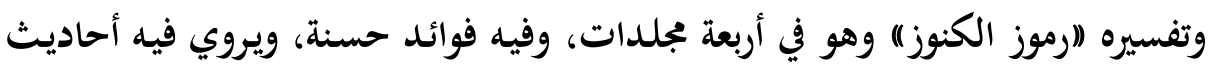

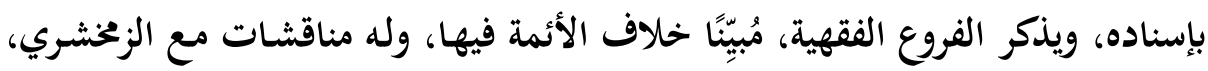

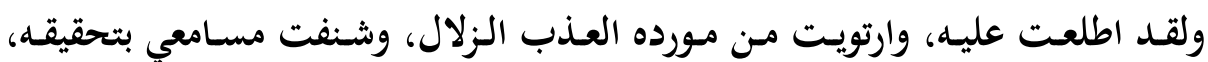

وارتويت من كوثر تدقيقه)|"(r)

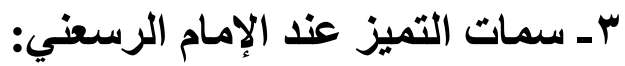

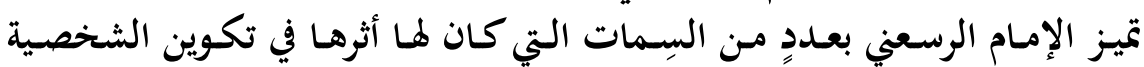

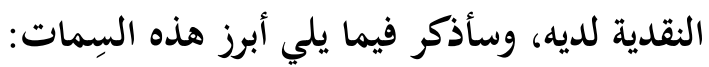

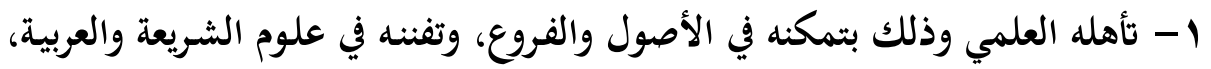
مع إفادته من مؤلفات أهل العلم. باتل

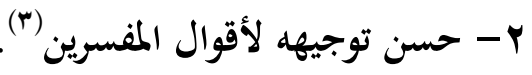

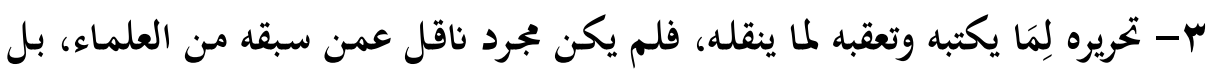

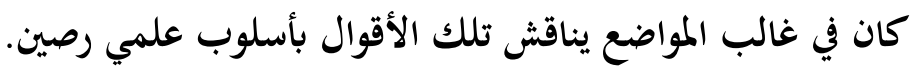
ع - بيانه لوجه النقد ودليله، واستناده عند النقد إلمى قواعد وأسس علمئية

ه- تضمن تفسيره استنباطات واجتهادات تدل على رسوخه العلمي (๕). ج- تحليه بالأمانة العلمية في نقله وإفادته عن غيره من أهل العلم (ه).

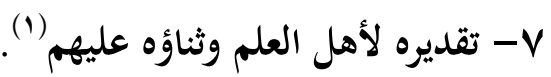




\section{الفصل الأول \\ أساليب النقد وصيغه عند الرسعني}

$$
\text { وفيه مبحثان: المبحث الأول: أساليب النقد عند الرسعني }
$$

من خلال استقراء تفسيره تبين لي أنه سلك في نقده أربعة أساليب، وهي: لإلئ أولاً: نقد القول وعزوه لقائله دون بيان مستثده في النقد، ومن الأمثئة:

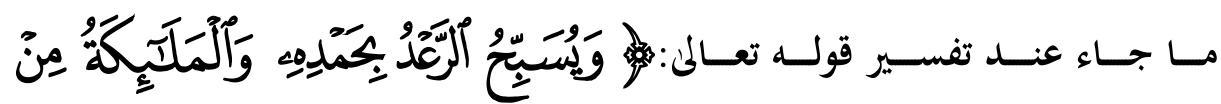

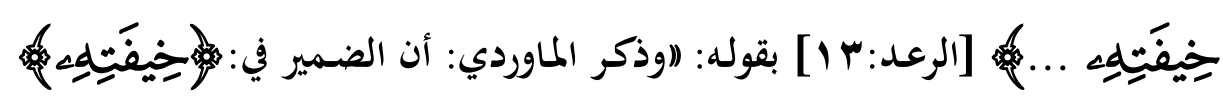

$$
\text { يرجع إلى الرعد. وليس بشيء") }
$$

ثانيًا: نقد القول وعزوه لقائله مع بيان مستثده في التقد، ومن الأمثلة:

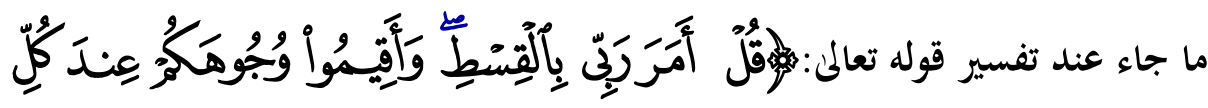
مَستجِحِِ كنتم إلى الكعبة. وفي هذا القول نظر؛ لأن الآية مكية، والأمر بالتوجه إلى الكعبة كان

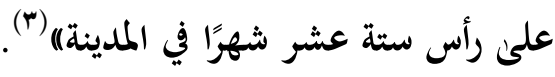
ثألثا: نقد القول دون عزوه لقائله ولا بيان مستثده في النقد، ومن الأمثلة:

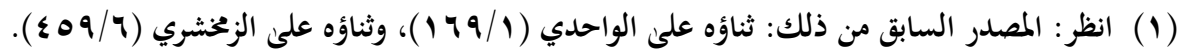

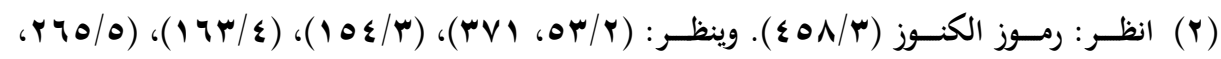
(

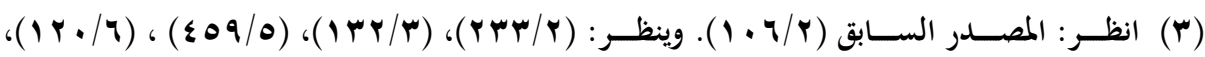
.( $(r q / \Lambda) ،(Y) \neg / V)$ 


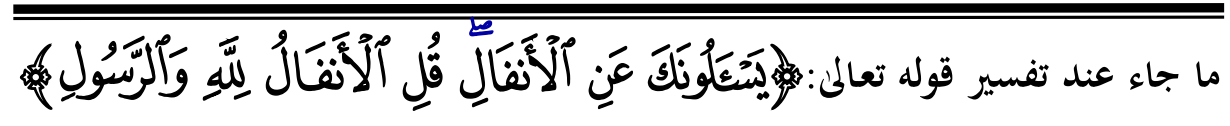

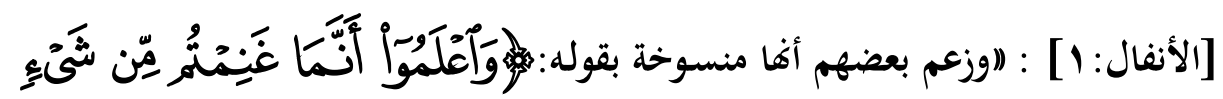

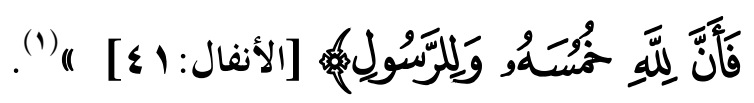
رابعًا: نقد القول مع بيان مستتده في النقد دون عزوه لقائله:

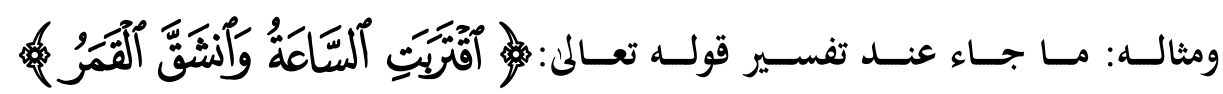

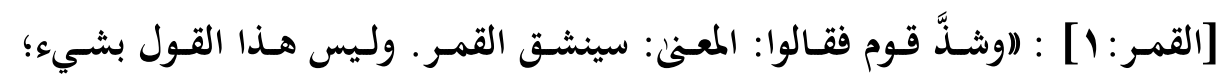

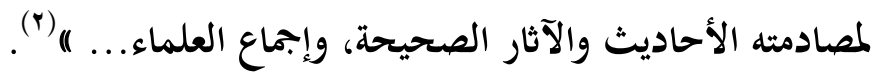

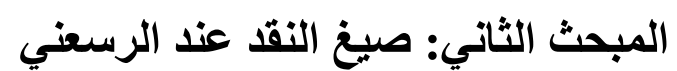
استعمل الرسعني في نقده صيغًا متعددة أوردها فيما يلي مع ذكر التئ مثال لكل منها.

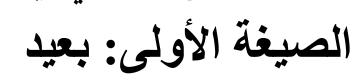

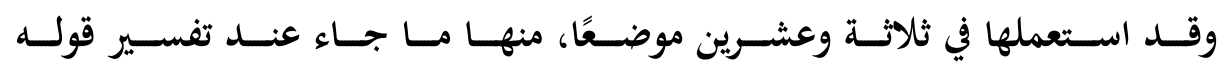

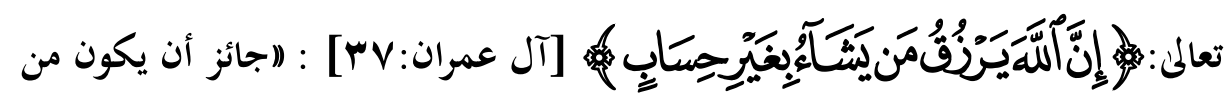

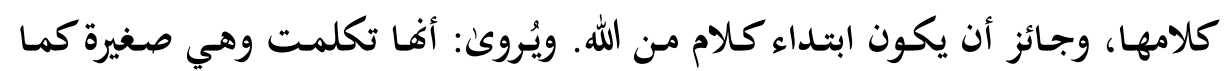

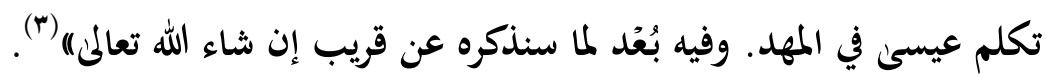

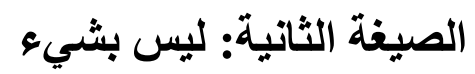

(1) انظـر : المصــر السـابق (ץ/\%)

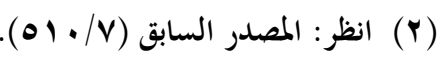

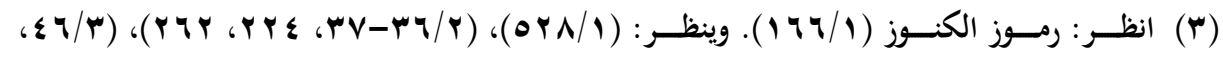

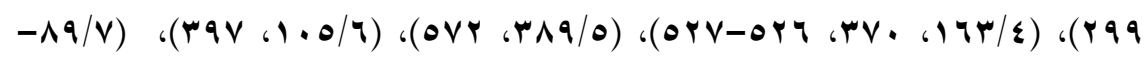

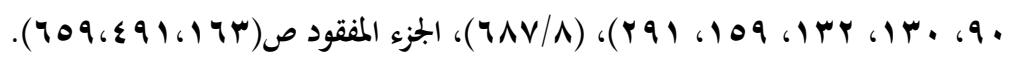




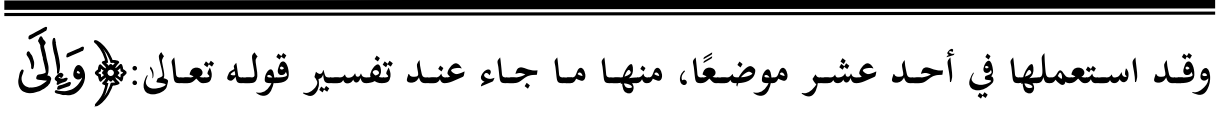

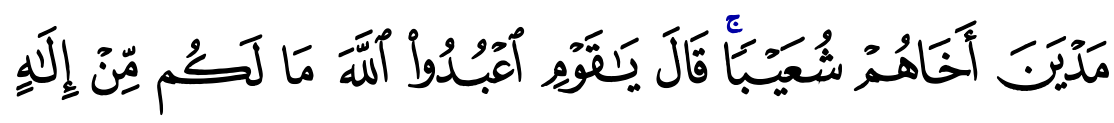

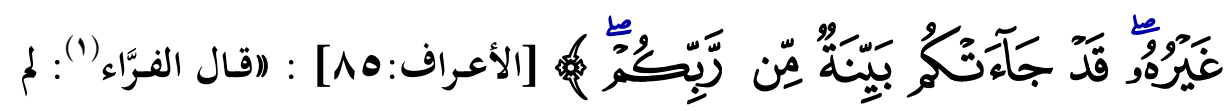
تكن له آية إلاً النبوة. وليس هذا القول بشيء؛ لأنه يستلزم إيباب التصديق والانقياد

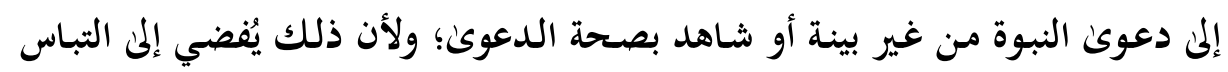
الحقى بالباطل. ولأنه يُفضي إلى محال، وما يُفضي إلى المحال محاله" (؟).

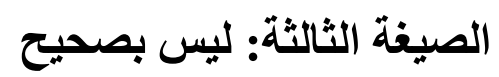

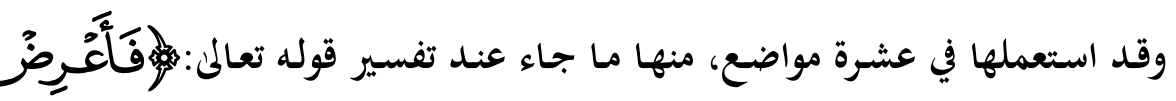

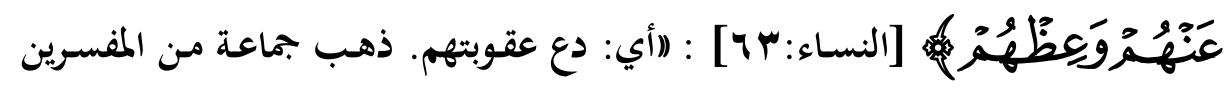

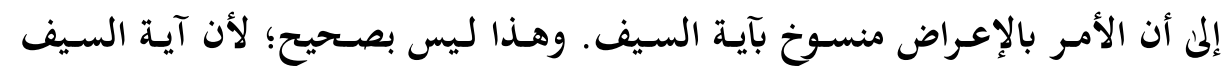

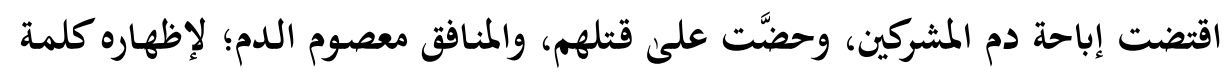
الحقى")

الصيغة الرابعة: غير مستقيم

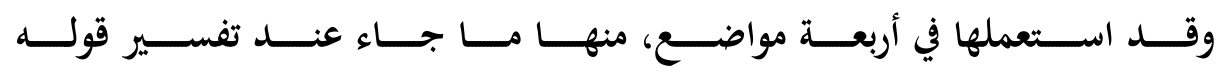

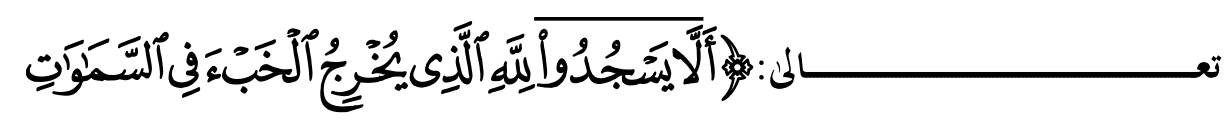

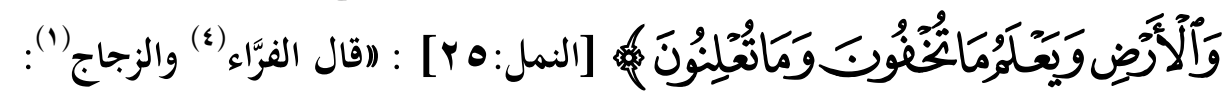

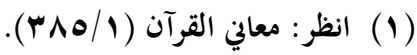

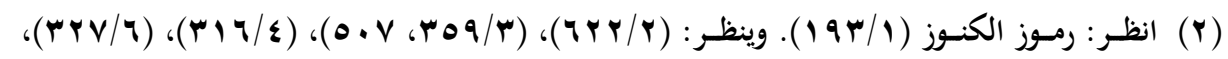

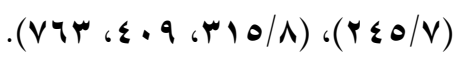

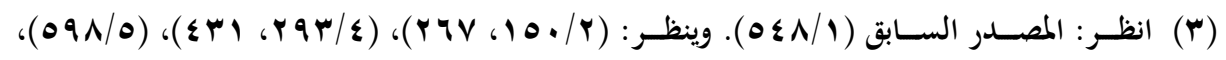

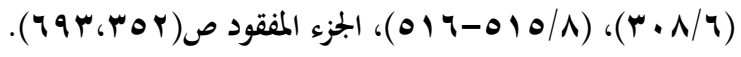

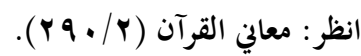




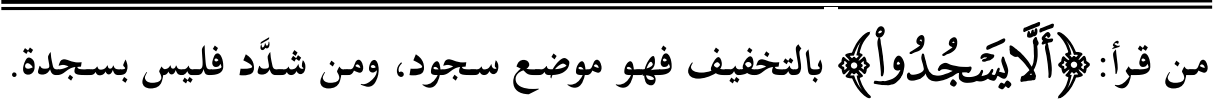
وهذا غير مستققيم؛ لأنه موضع سـجدة بإجماع العلمـاء المشهورين لا نعـرف بينهم فيـه

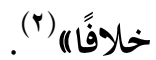

\section{الصيخة الخامسة: تعسف}

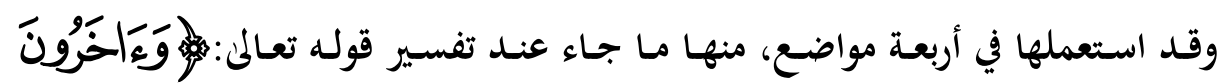

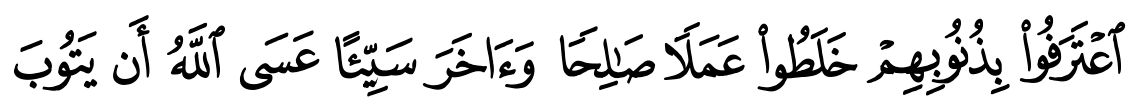

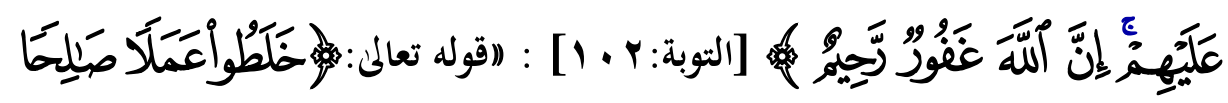

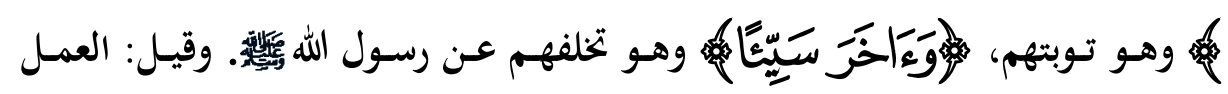
الصـاح: مـا سبق لهم من الجهاد، والعمل السيء: تخلفهم عن غزوة تبوك. وقال ابن

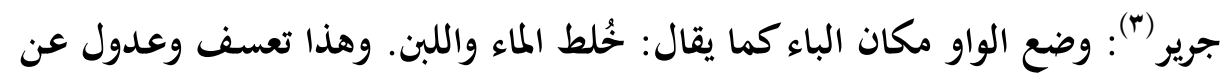
حقيقة اللفظ، فبإن الواو جعلت كل واحسد من العملين مخلوطًا بـه، وكذلك في النظير الذي ذكره، فإنه جعل الماء واللبن مخلوطين ومخلوطًا بجما، كأنك قلت: خلط الملاء باللبن واللبن بالماء)" (ع). الصيغة السادسة: فاسد

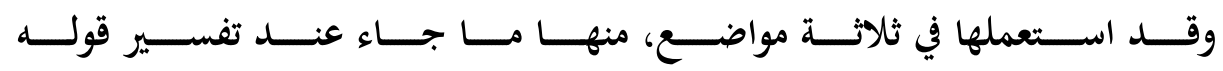

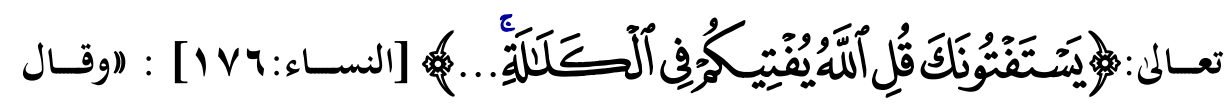
صاحب الكشاف(•): المراد بالولد: الابن؛ لأن الأخت تسقط بـه، ولا تسقط بالبنت،

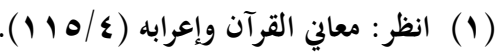

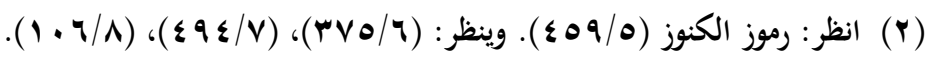

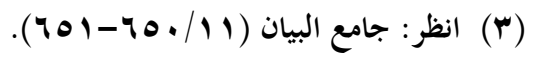

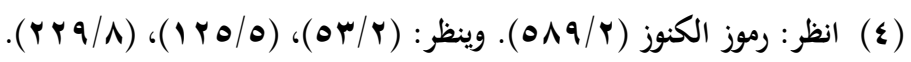

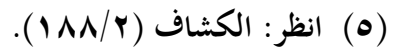


وتابعه على ذلك صاحب (التقشير في التفسير) وأبو السعادات ابن الأثير في تفسيره الذي سمَّاه (الإنصاف)، وضمَّن فيه الجمع بين (الكشف) و ((الكشاف)، ولم يُنَبها على

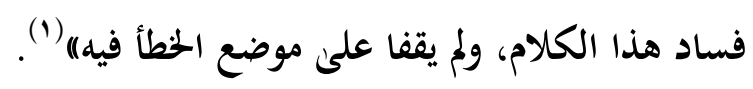

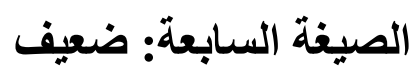

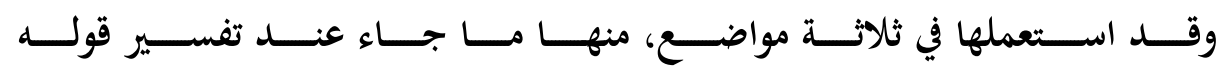

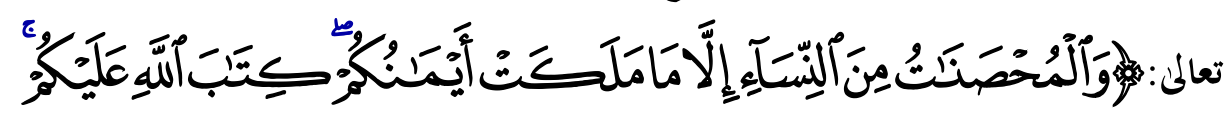

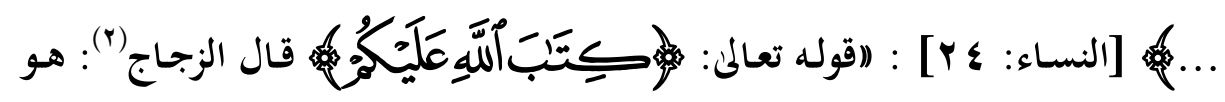
مصدر مؤكد، أي: كتب الله عليكم كتابًا. وقال نحاة الكوفة: هو منصوب على الإغراء بـ (عليكم)، وفيه ضعف؛ لأن ما انتصب بالإغراء لا يتقدم على ما قام مقام الفعل)" (r).

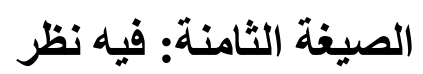

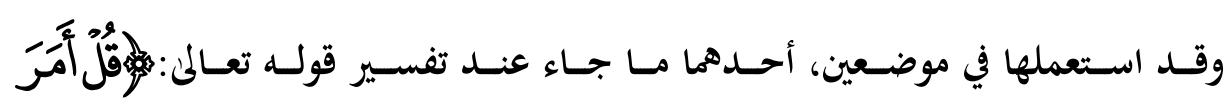

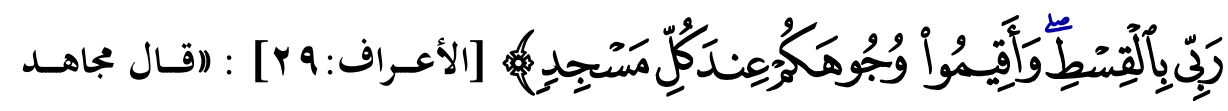
والسدي وابن زيد: وجهوا وجوهكم حيث كنتم إلمى الكعبة، وفي هذا القول نظر ؛ لأن الندان

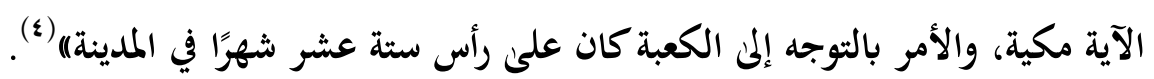

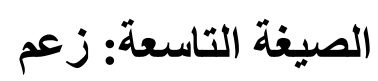

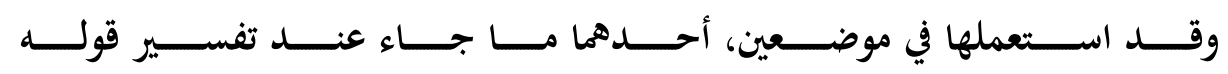

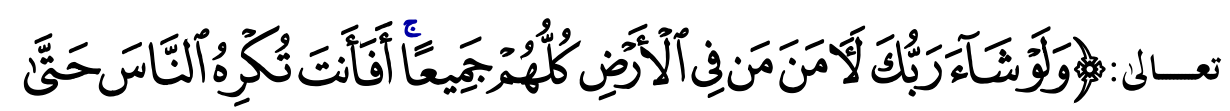

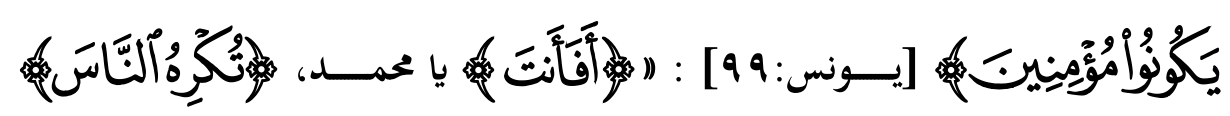

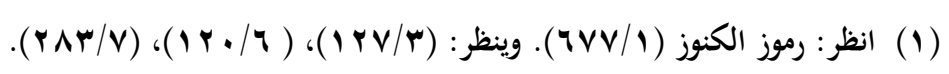

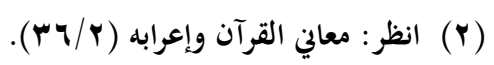

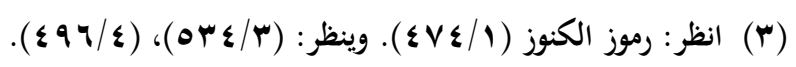

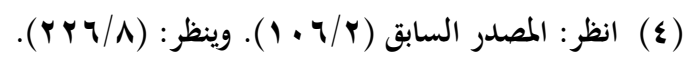




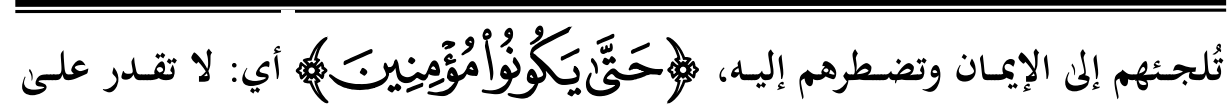
ذلك ولا هو في وسعك. وزعم قوم أن هذا منسوخ بآية السيف، ولا يصح؛ لأن المقصود

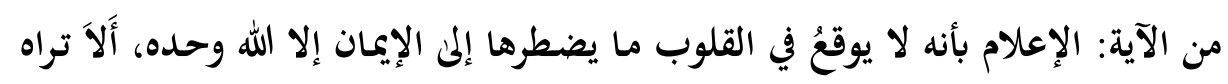

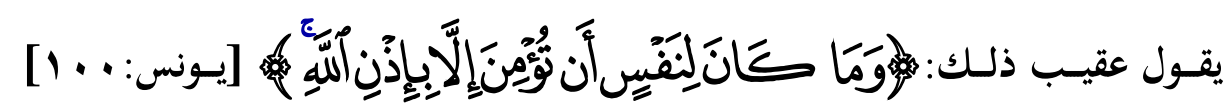
(1) "I

الصيغة العاشرة: باطل

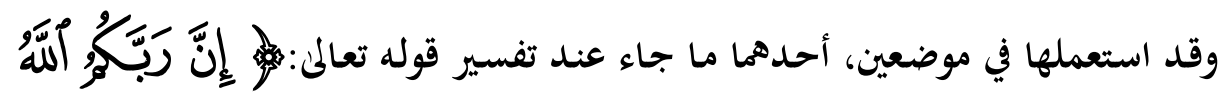

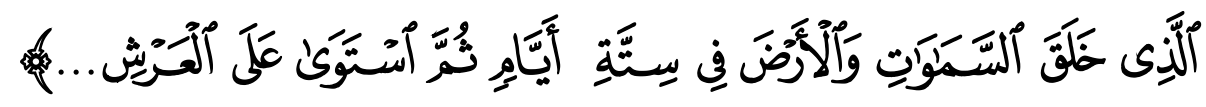

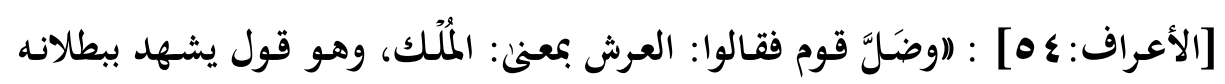

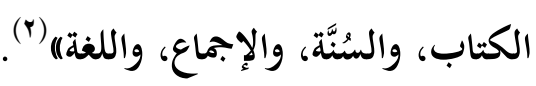

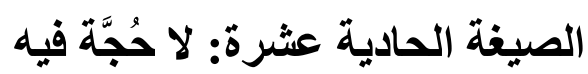

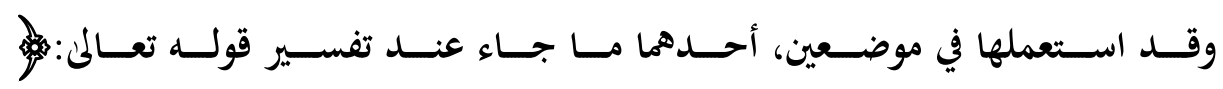

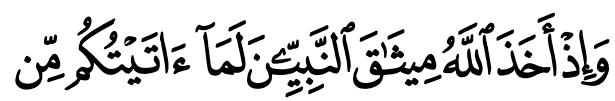

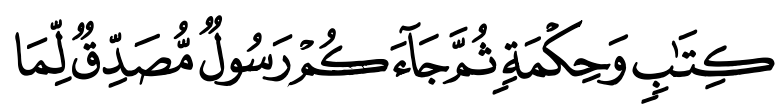

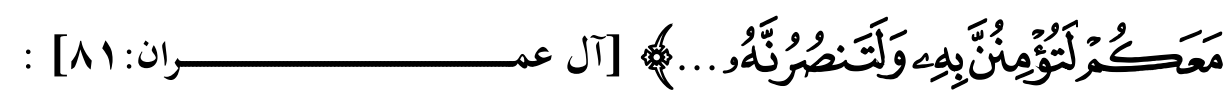

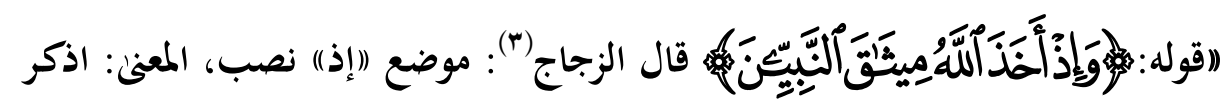
في أقاصيصك إذ أخذ الله. قال ابن عباس: والميثاق: العهد، وهو العهد الذي أخذه الله

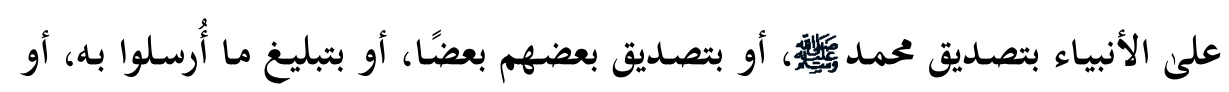

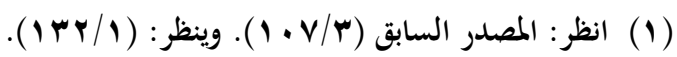

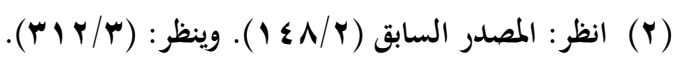

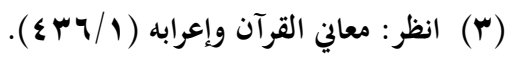


هو الميثاق الذي أخذه الأنبياء على أمُهم، أو هو على حذف المضاف، أي: ميثاق

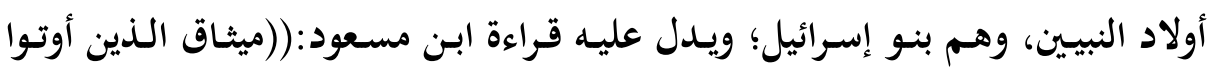

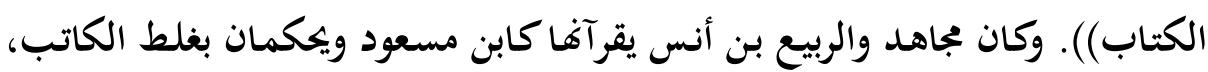

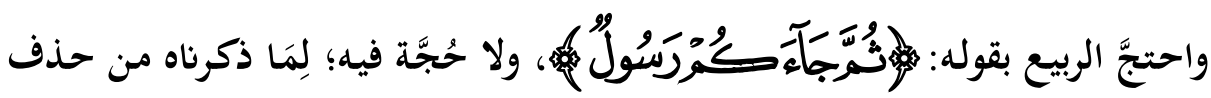
(المضاف" (1) الصيغة الثانية عثرة: سهو المضاف

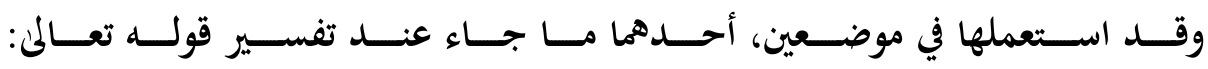
و

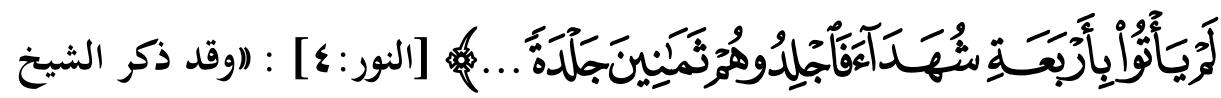
أبو الفرج ابن الجحوزي رضي الله عنه في زاد المسير في تفسير هذه الآيـة(؟): أن شرائط

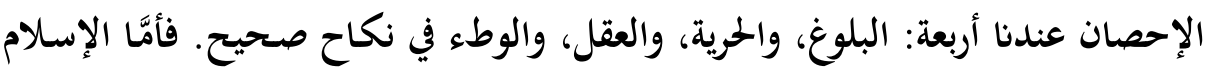
فليس بشرط في الإحصان. وهذا سهوٌ بلا شك، فإِن هذه الأوصاف شرائط الإحصان الذي يتوقف وجوب الزجم على الزاني أو الزانية عليه)(").

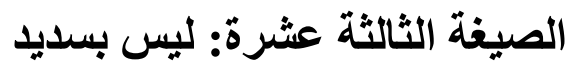

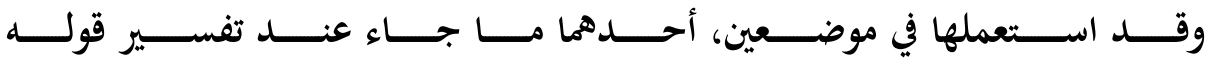

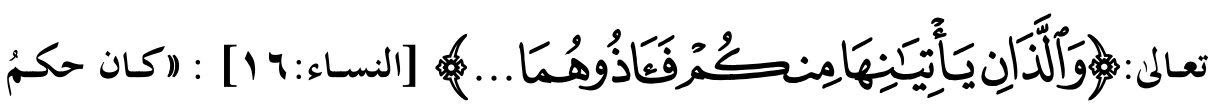
الزانية في صدر الإسلام أن تُحُبس في البيت حتن تموت، وحكم الزاني أن يُؤذنى، كما قال

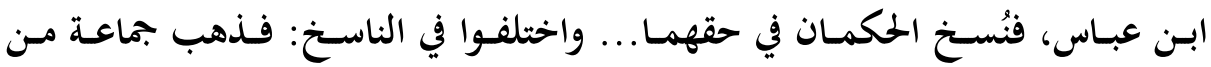

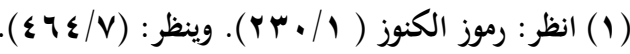

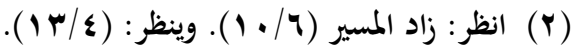

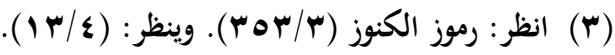


المفسِّرين إلمى أنه نسـخ بحديث عبادة بـن الصامت...، وهذا القول ليس بسـديد؛ لأن

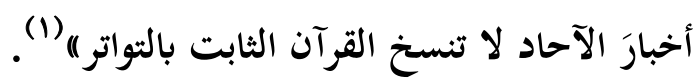

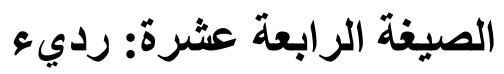

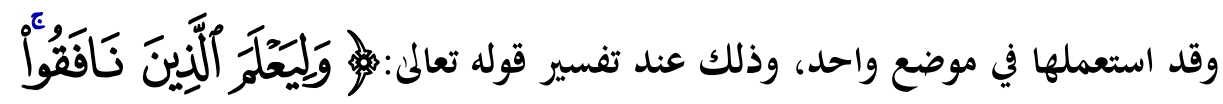

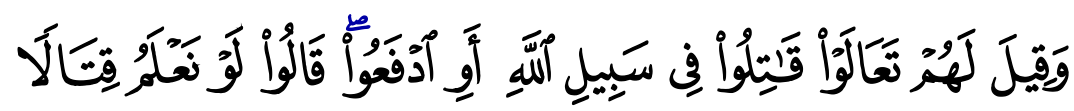

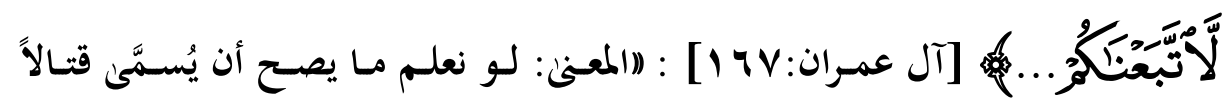

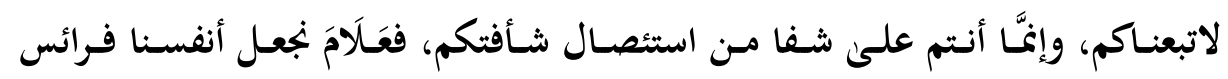

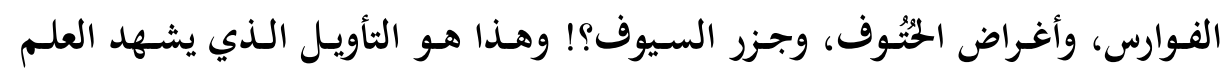

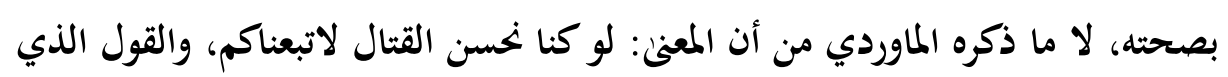
ذكره الماوردي رديء جدًا)('ال) الصيغة الخامسة عشرة: مدخول فيه

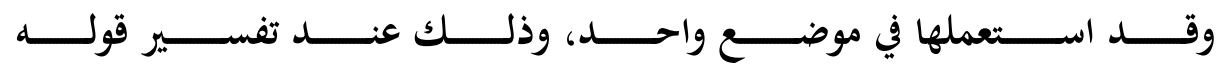

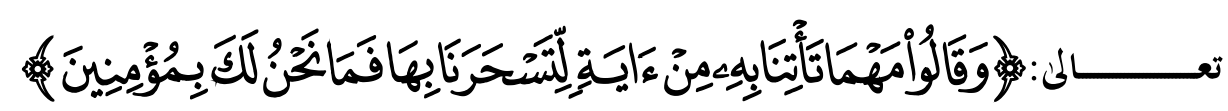

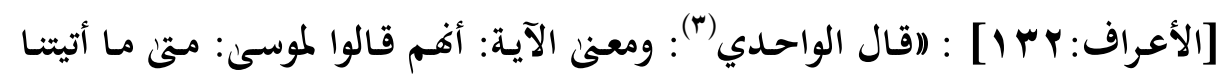

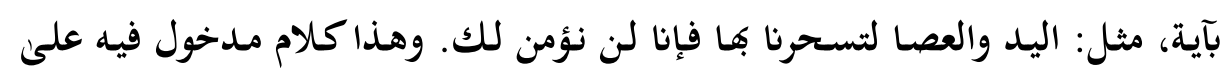

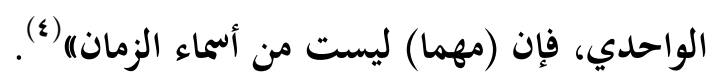

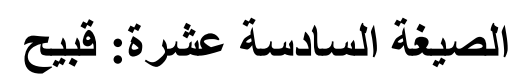

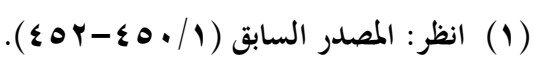

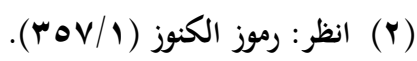

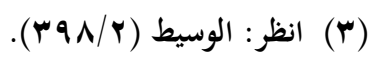

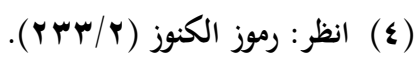




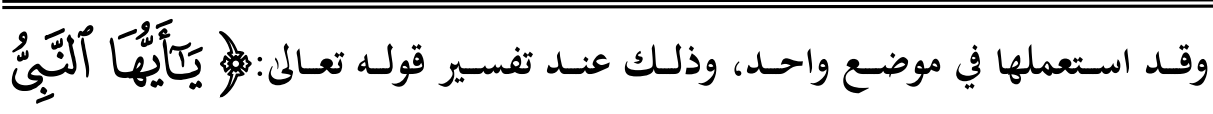

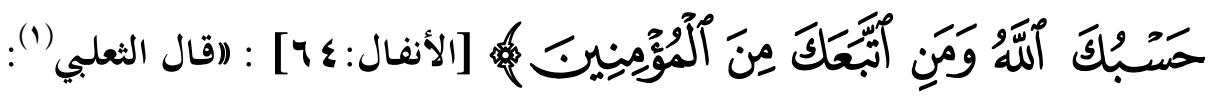

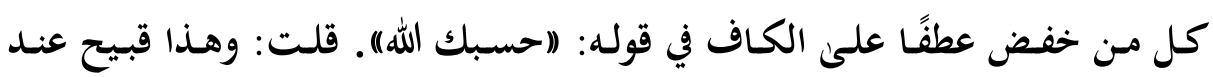

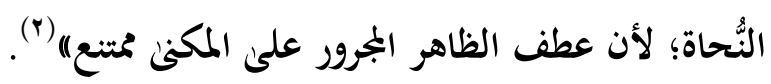

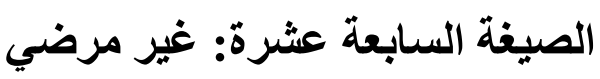

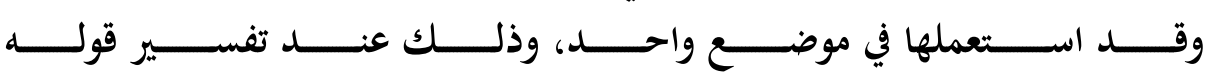

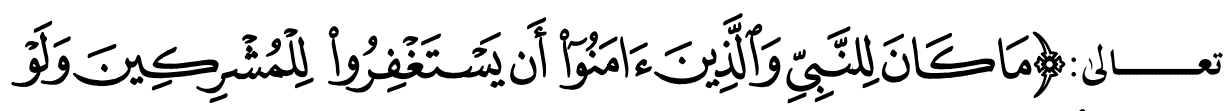

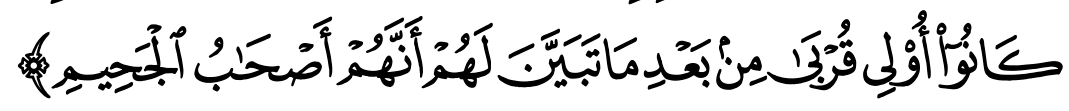

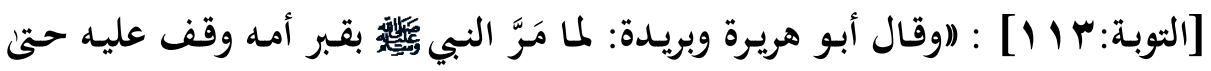

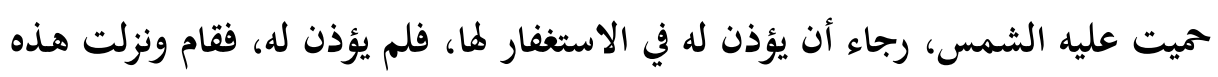

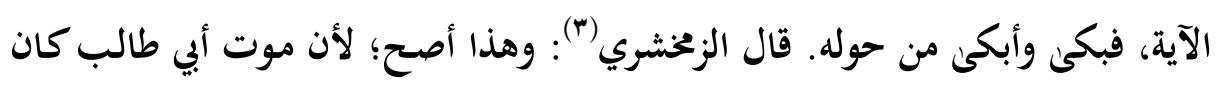

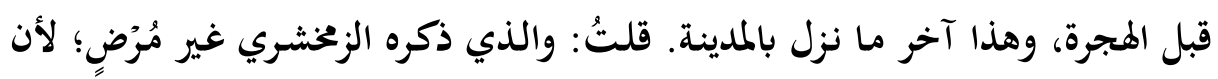

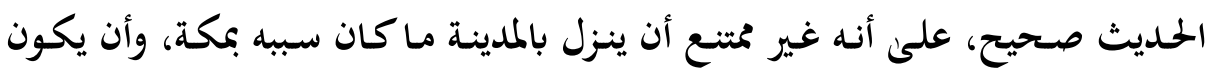

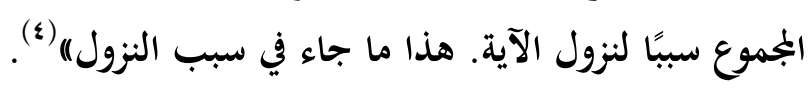

\section{الصيغة الثامنة عشرة: لا دلالة فيه}

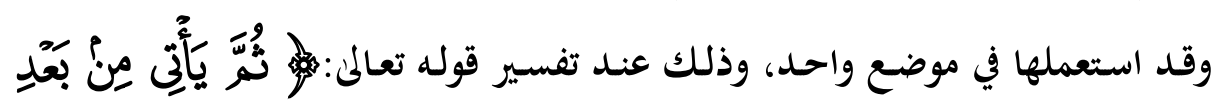

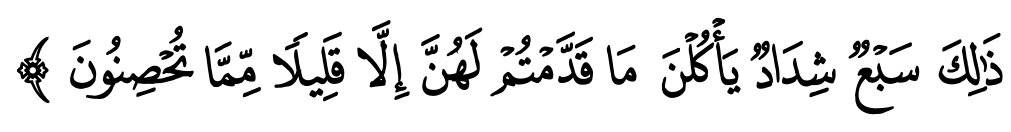

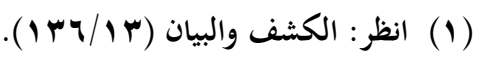

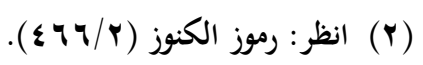

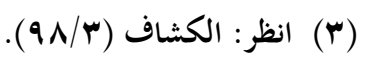

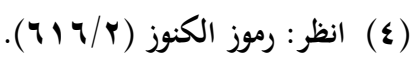




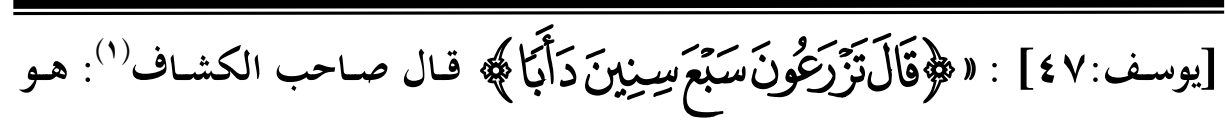

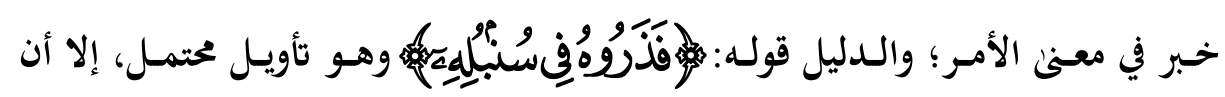

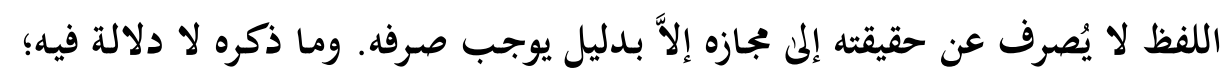

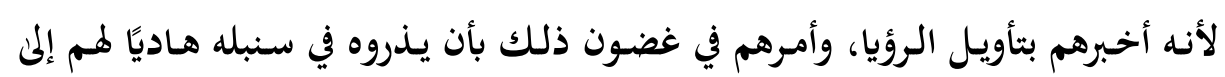
المصلحة)" (r). الصيغة التاسعة عشرة: تعجرف في التأويل

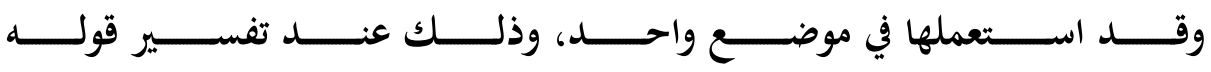

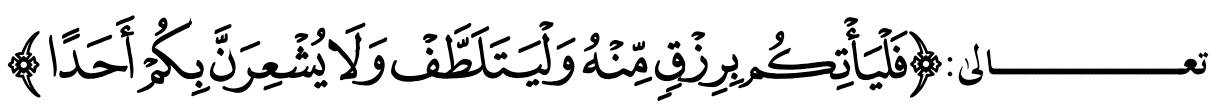

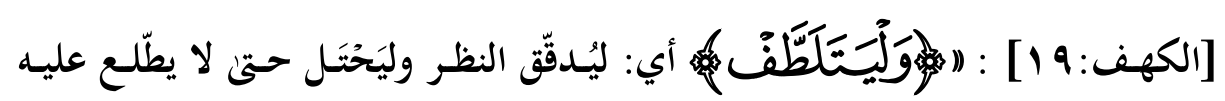

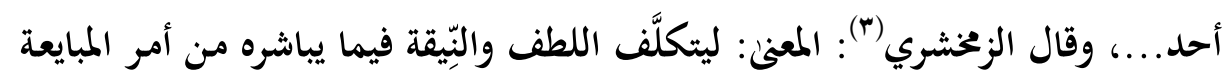

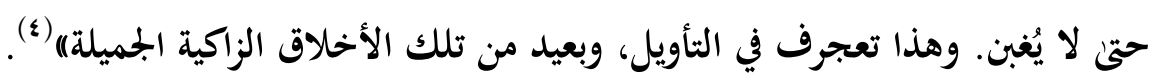
الصيغة العشرون: غفلة

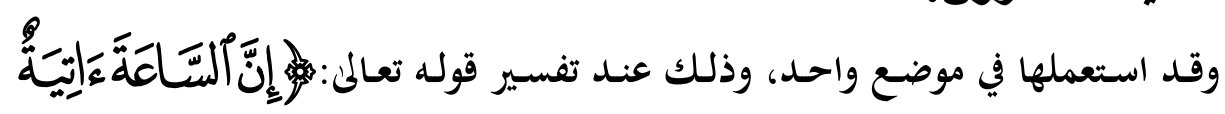

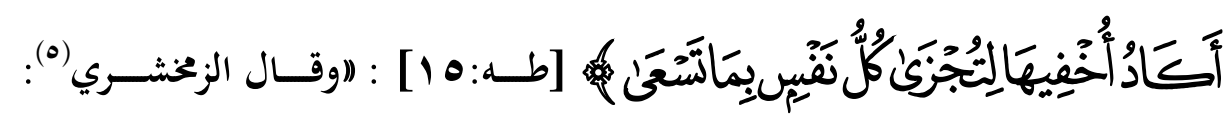

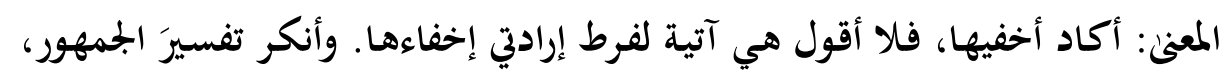

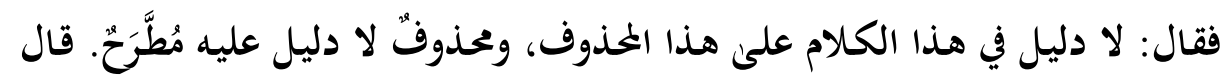

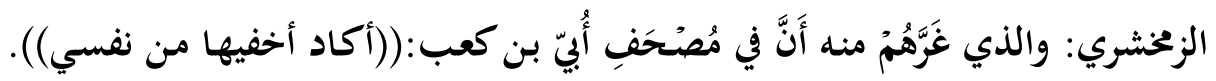

$$
\begin{aligned}
& \text { (1) انظر: الكشاف (Y/Y (Y (Y). }
\end{aligned}
$$

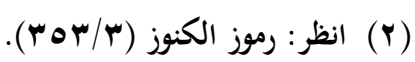

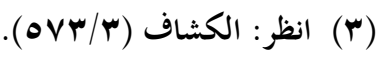

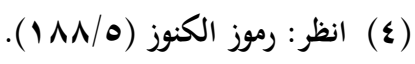

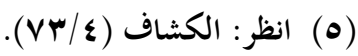




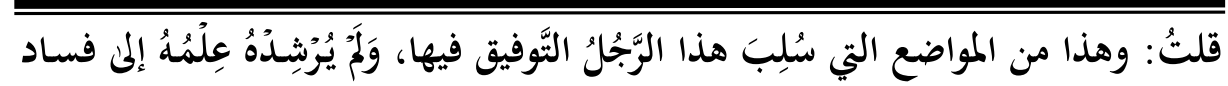

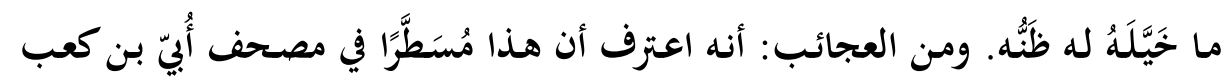

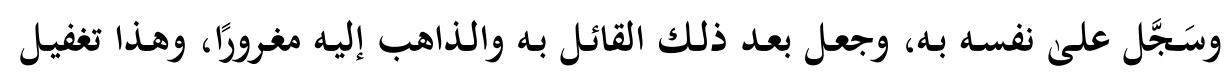

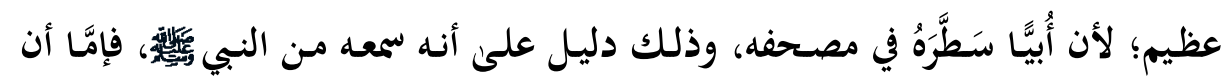

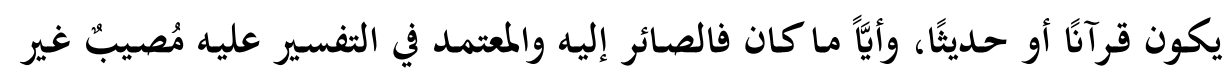

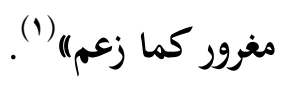

\section{الصيغة الحادية والعثرون: بعيد عن التحقيق}

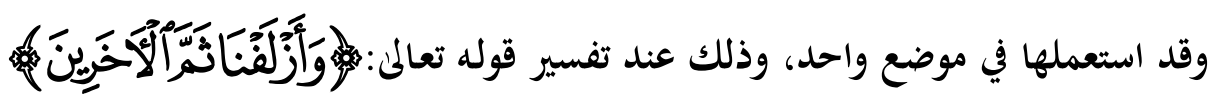

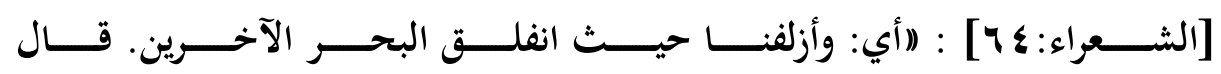

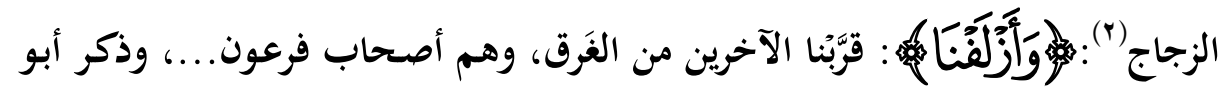

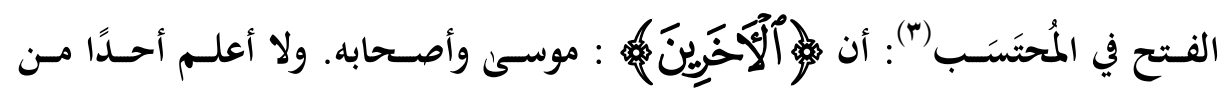
المفسرين ذكر هذا الوجه الذي ذكره، وهو بعيد من التحقيق||(؛).

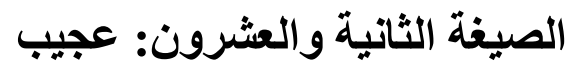

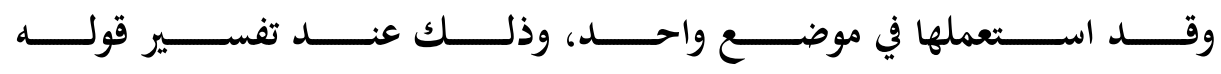
تعالمن :

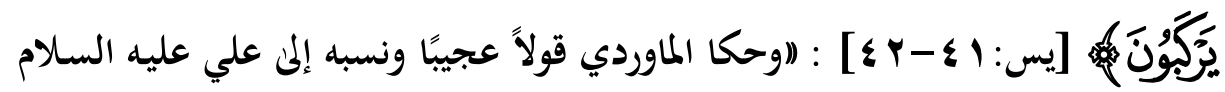
قال (•): الذرية: النطف حملها الله تعالم في بطون النساء تشبيهًا بالفُلك المثحون، قال:

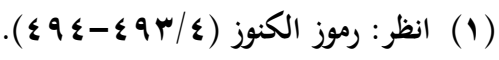

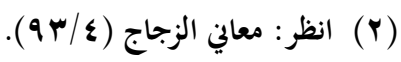

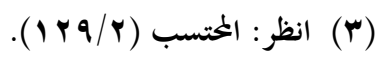

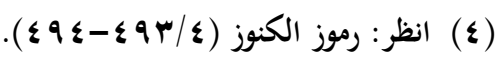

$$
\begin{aligned}
& \text { (0) انظر : النكت والعيون (0/9 (1) ). }
\end{aligned}
$$




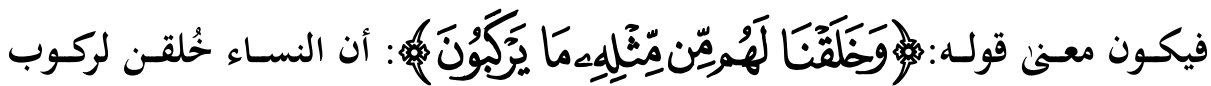

$$
\text { الأزواج " (1) }
$$

الصيغة الثالثة و العشرون: غير جائز

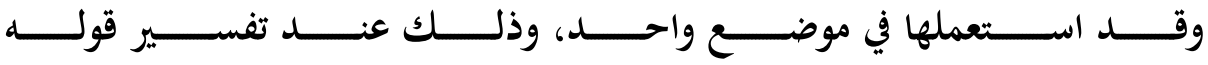

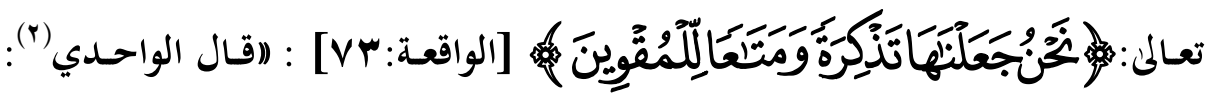

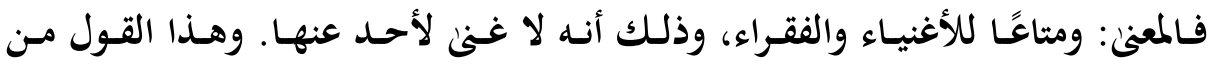
الواحدي فيه إشعار أن اللفظة الواحدة تُستعمل في الثيء وضده في حالة واحدة، وهذا

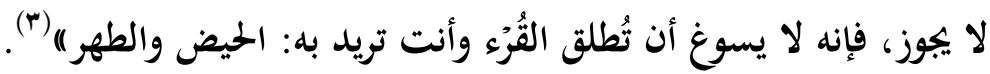

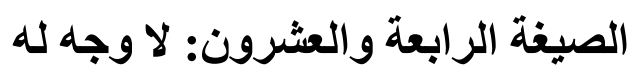

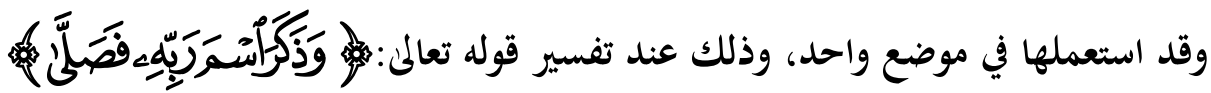
[الأعلى:010] : اقال ابن عباس: ذكر معاده وموقفه بين يدي الله، فصلَّلى الصلوات الحخمس. وقال الضحاك: ذكر اسم ربه في طريق المصلَّى، فصلَّى صلاة العيد. وقال أبو

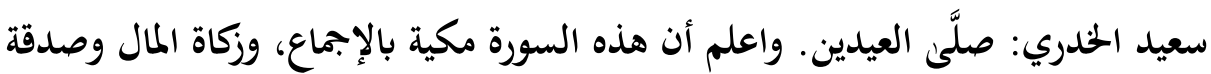

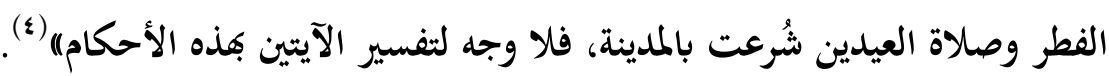

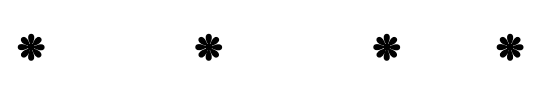

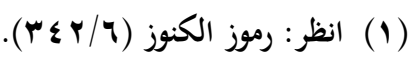

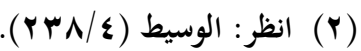

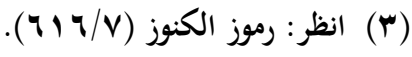

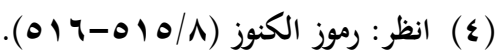




\section{الفصل الثاني \\ أسس النقد ومجالاته في تفسير الرسعني}

وفيه مبحثان:

المبحث الأول: أسس النقد في تفسير الرسعني

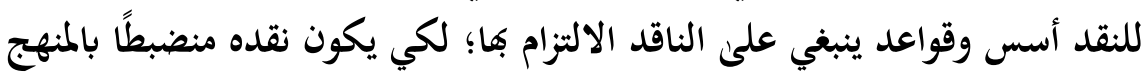

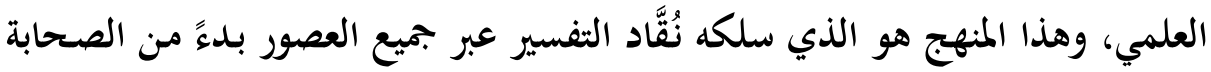

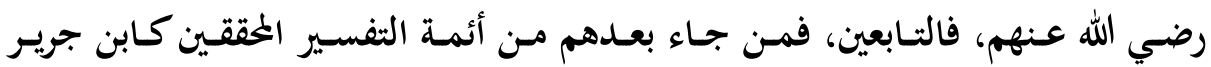

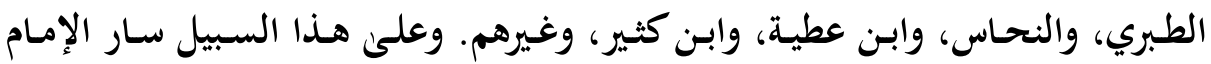
الرسعني مستندًا في نقده على أصول وأسس علمية، وفيما يلي عرض لهذه ولئ الأسس:

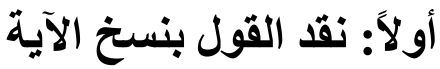

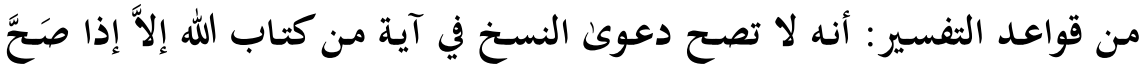

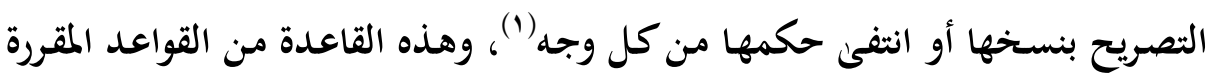

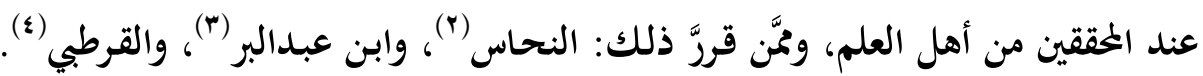
وهذا ما أكدَّ عليه الرسعني وحرص على تطبيقه في تفسيره، ونصَّ عليه بقوله: (اوللنسخ شروط ليس هذا موضع استقصائها والتقصي عنها، فينبغي لمن أراد تحقيق هذا العلم أن

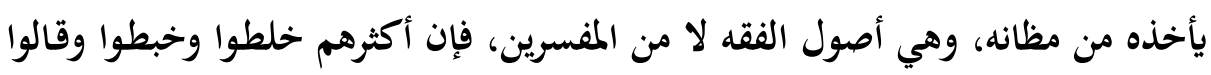

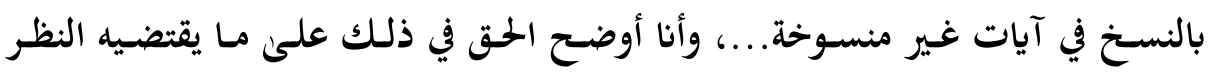
الصحيح والبحث المستقيم" (0) . وقد فندَّ الرسعني في تفسيره عددًا من دعاويى النسخخ التي توسع في إيرادها بعض

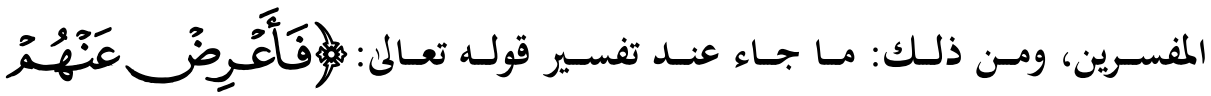

$$
\begin{aligned}
& \text { (1) انظر : قواعد الترجيح بين المفسرين (Y/l (Y). }
\end{aligned}
$$

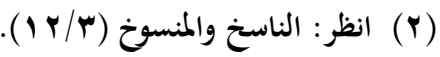

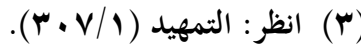

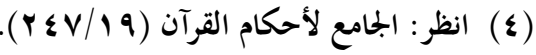

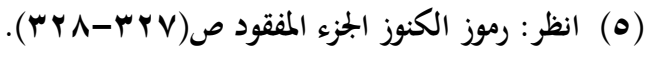




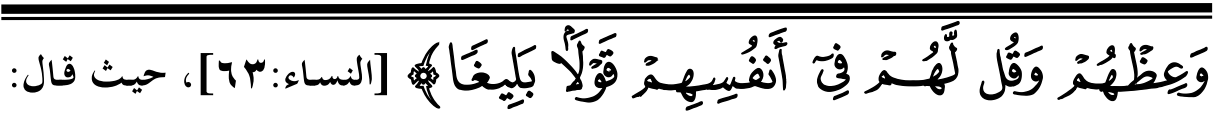

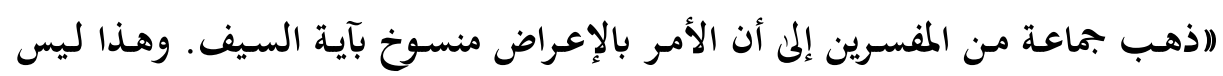
بصحيح؛ لأن آية السيف اقتضت إباحة دم المشركين، وحضَّت على قتلهم، والمنافق

معصوم الدم؛ لإظهاره كلمة الحقى" (1).

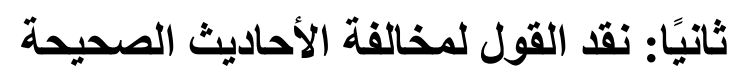

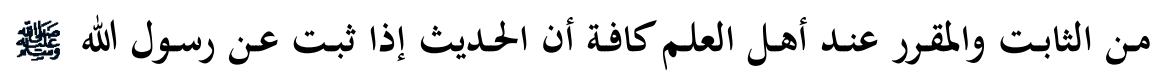

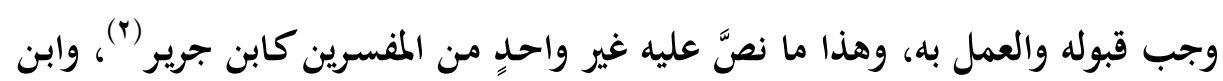

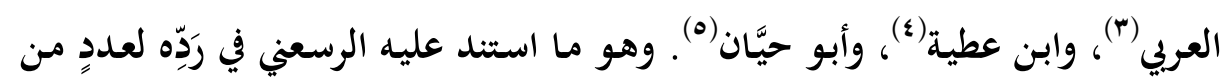

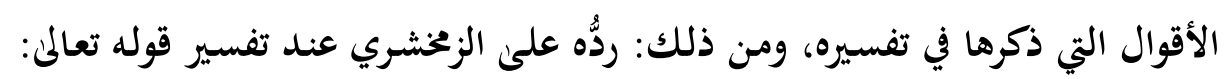

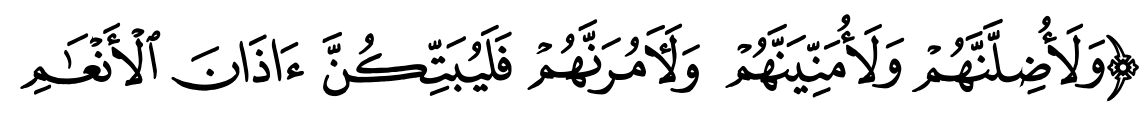

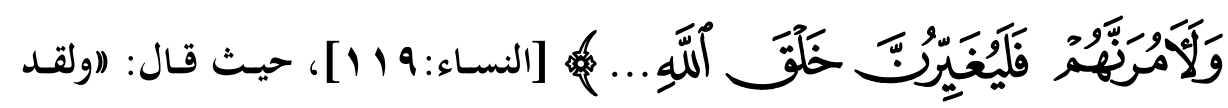
عجبتُ من كشف صاحب الكشاف قِنَاع الحياء، ورفضه الأحاديث الصحيحة الصريحة

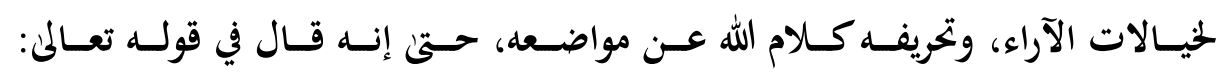

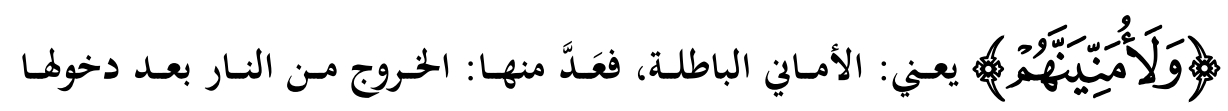

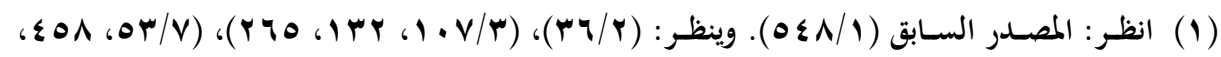
§

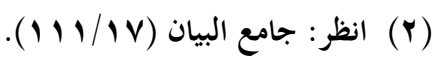

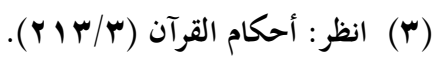

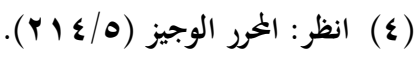

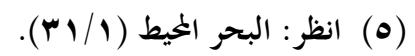




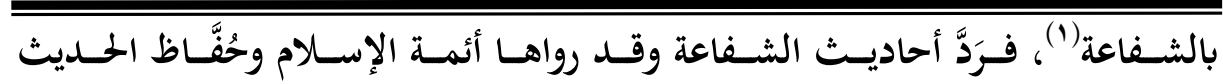

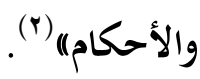

ثالثا: نقد القول لمخالفة دلالة السياق

من الواجب على المفسر أن يُراعي عند تفسيره دلالة السياق، فهي أحد الدلالالات

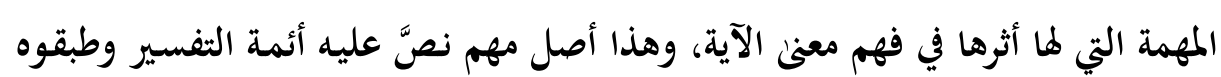

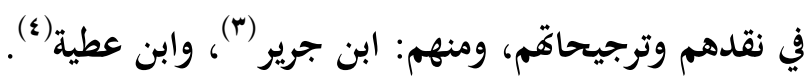

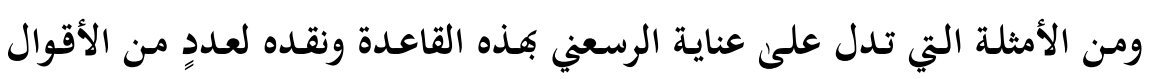

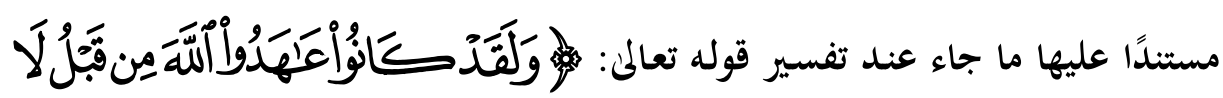

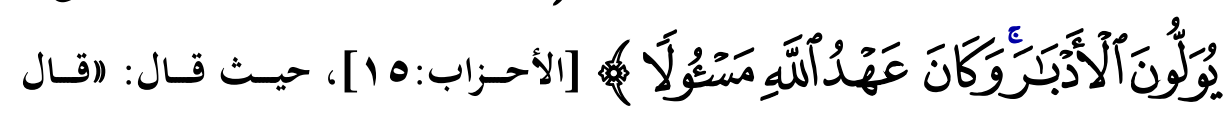

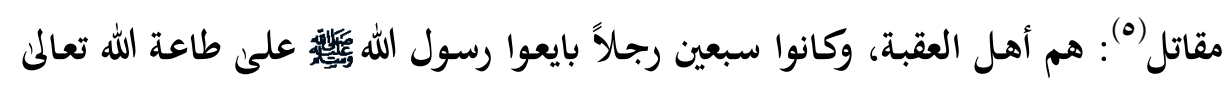

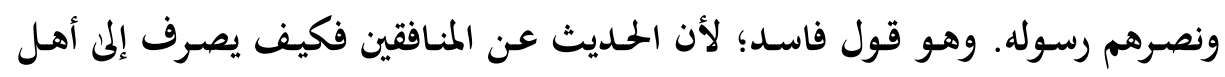
العقبة الذين هم أمثل أصحابه؟) (؟).

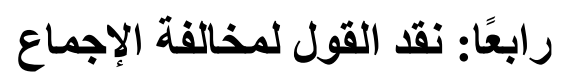

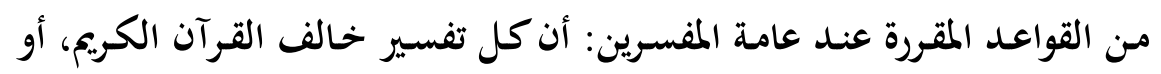

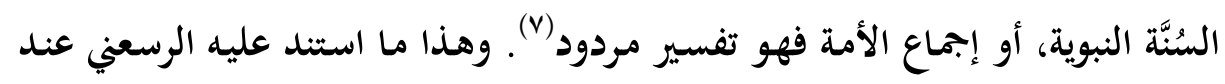

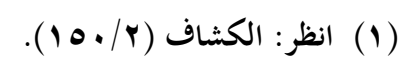

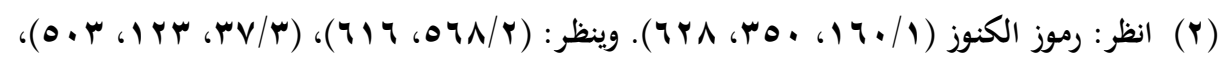

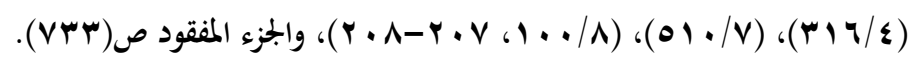

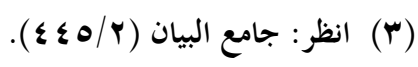

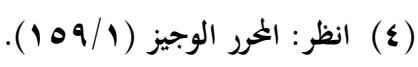

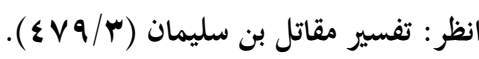

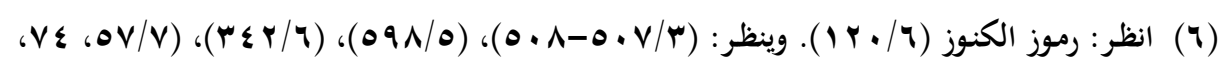
( ( $)$ (

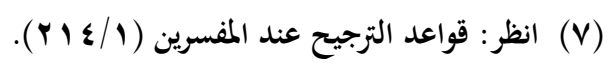




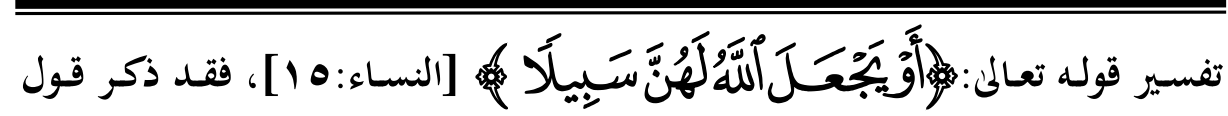
الزخشري بأن المراد من الآيـة هو النكاح الذي يستعففن بـه عن السفاح (1)، ثم قال:

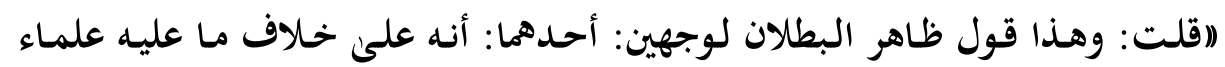

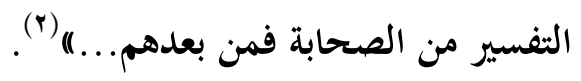

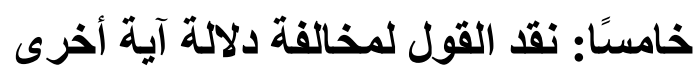

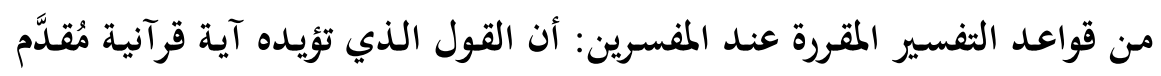

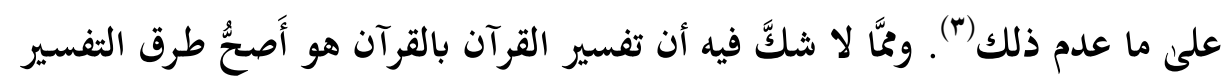

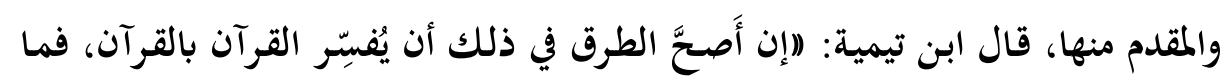

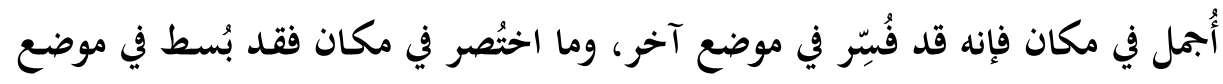

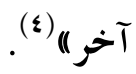
ومن الأمثلة التي استند فيها الرسعني على هذه القاعدة انتقاده للزخشري عند

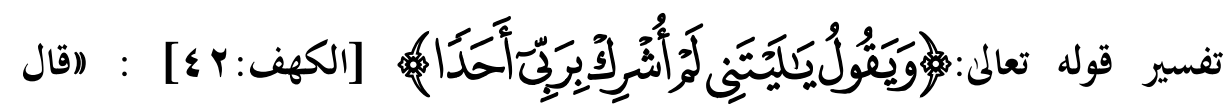

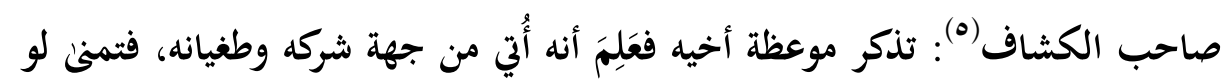

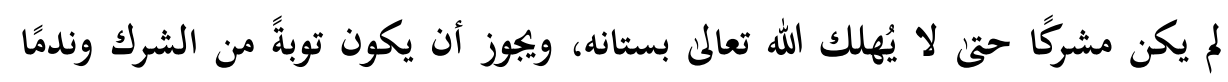

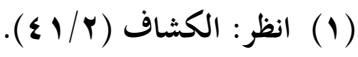

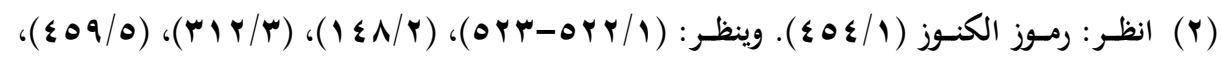
(707، (09 $1 / \Lambda)$ (109/v)

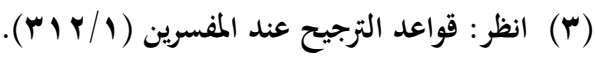

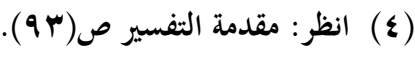

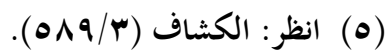


على ما كان منه ودخولاً في الإيمان. وليس هذا بصحيح؛ فإنه مات على كفره؛ بدليل

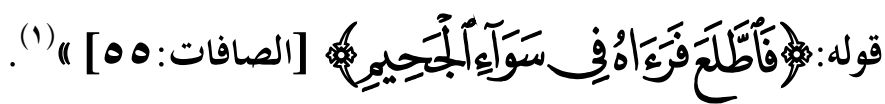
سادسًا: نقد القول لمخالفة ظاهر القرآن آنأن الأصل أن يُراعي المفسر عند تفسيره للآيات حملها على ظاهرها، ولا يجوز أن يعدل

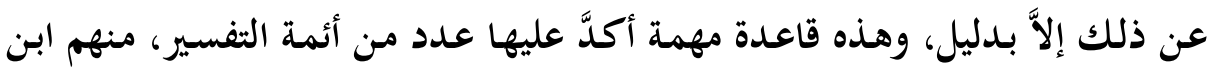

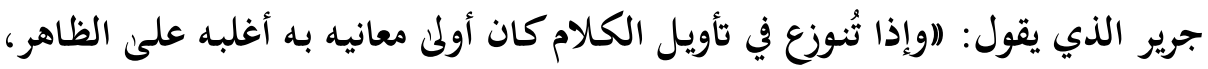

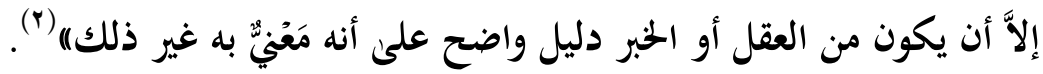

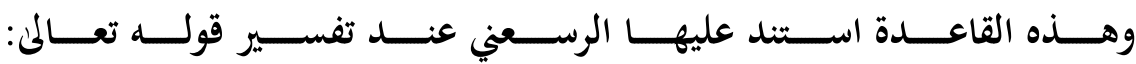
置 [آل عمران: 1 \&] ] حيث قال: (اقال الإمام أبو الفرج ابن الجوزي رضي الله عنه: جمهور العلماء على أنه إنما اعتقل لسانه آية على وجود الحمل (r). وقال قتادة والربيع بن أنس:

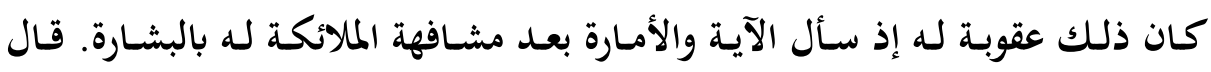
الثعلبي: قول قتادة قول أكثر المفسّرين. قلت: وهو قول يخالف ظاهر القرآنه|"(أ).

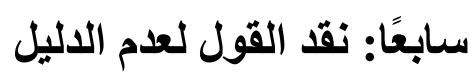

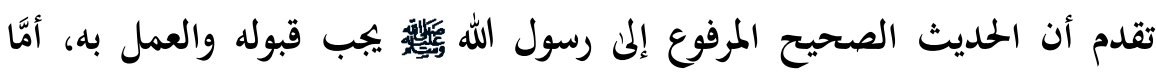

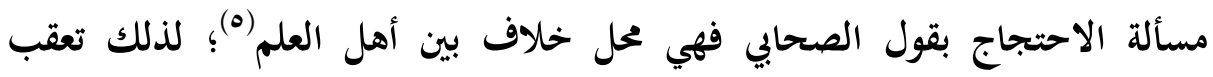

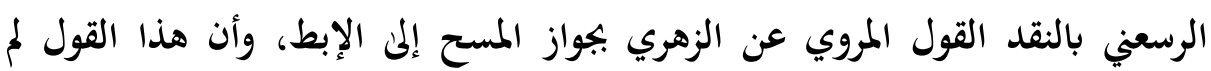

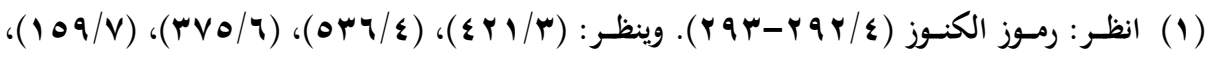

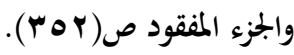

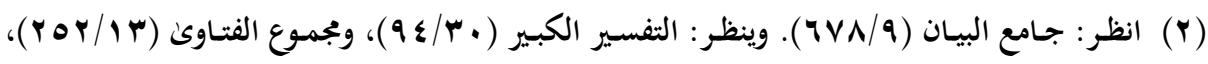

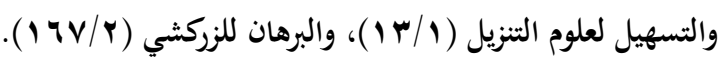

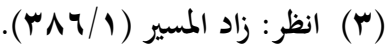

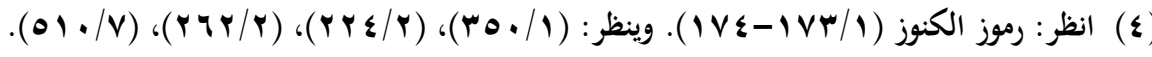

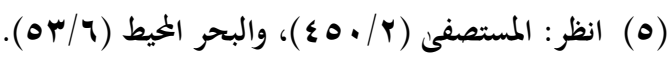




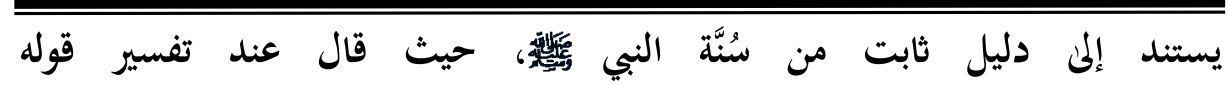

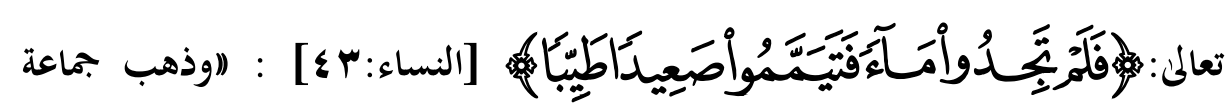
منهم ابن عمر، والحسن، وأبو حنيفة، والثوري، والثافعي إلمى أنه ضربتان: ضربة للوجه،

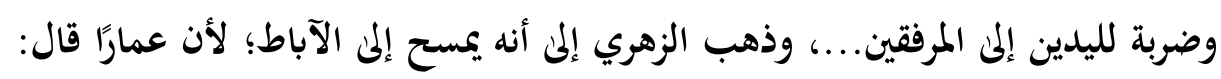

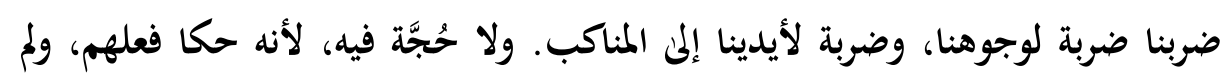

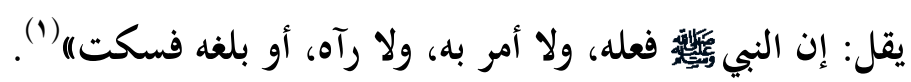

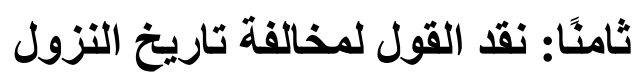

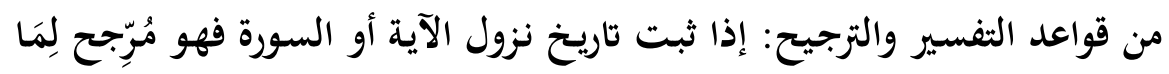

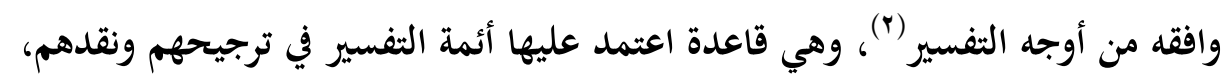

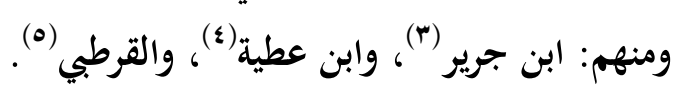

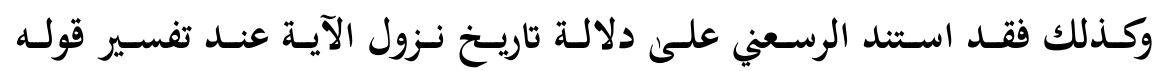

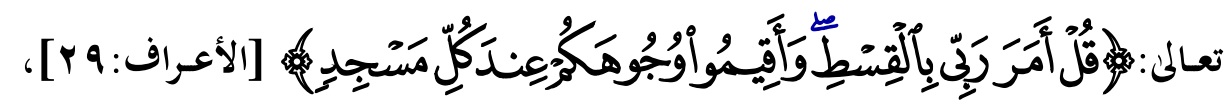
حيث قال: (اقال مجاهد والسدي وابن زيد: وجهوا وجوهكم حيث كنتم إلى الكعبة. وفي

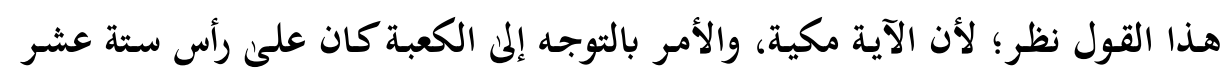

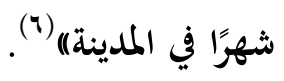

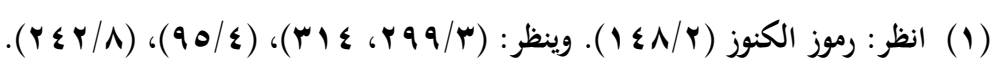

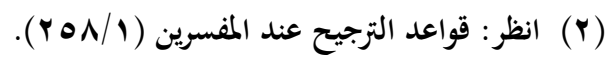

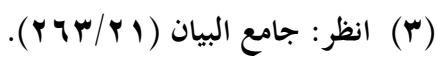

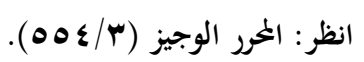

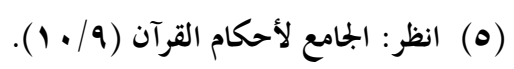

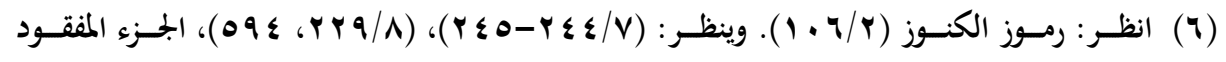




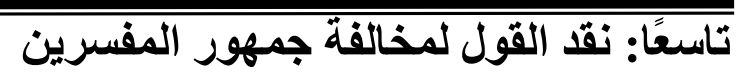
من الأسس والقواعد التي استند إليها أئمة التفسير في التزجيح والنقد: أند تفسير

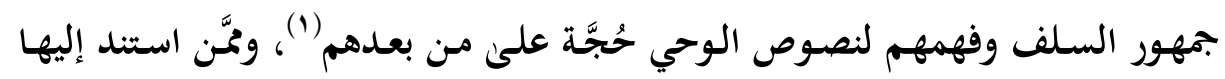

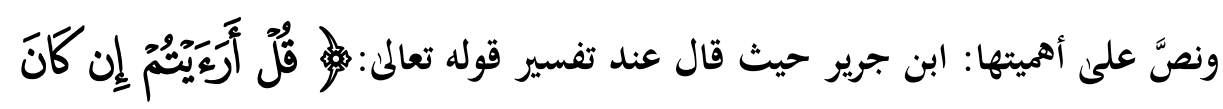

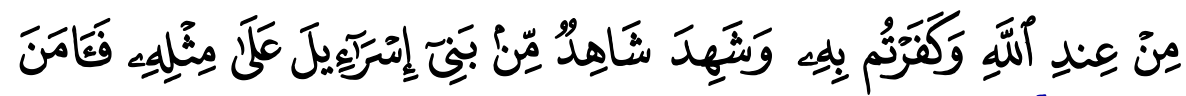

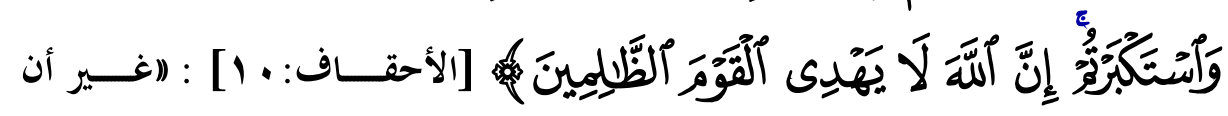

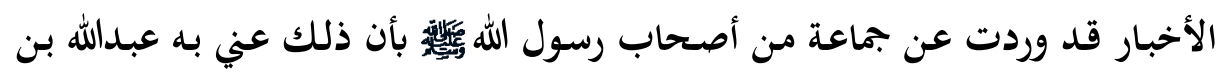

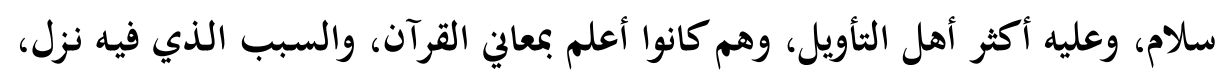
وما أُريد بهل|(؟).

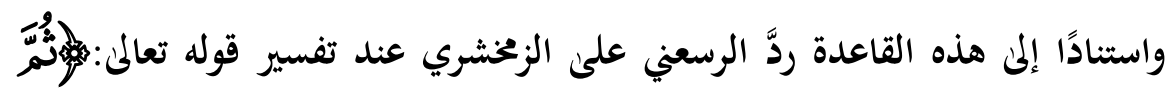

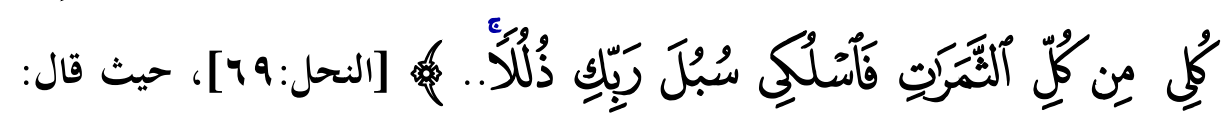

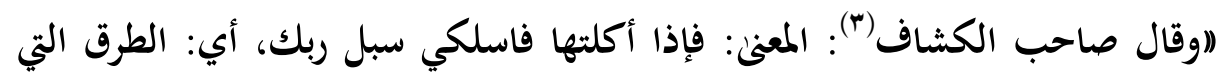

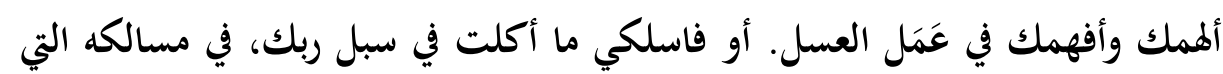

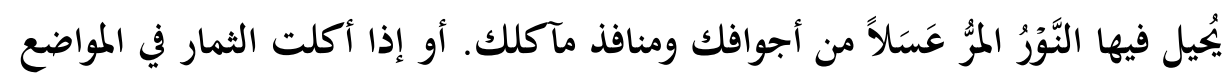

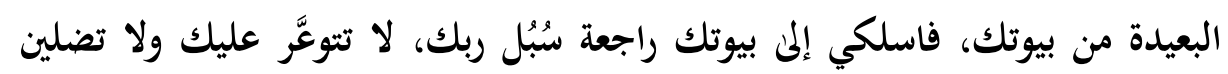

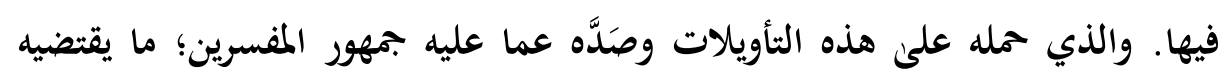

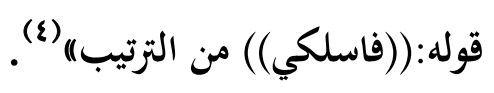

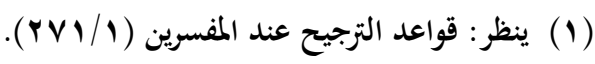

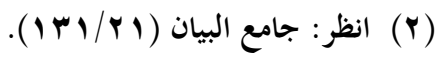

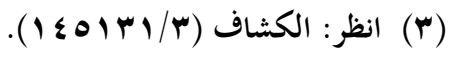

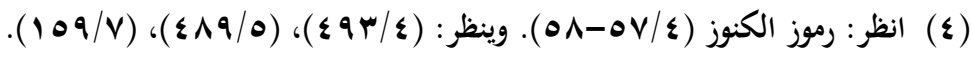




$$
\text { عاشرًا: نقا: القول لصرف اللفظ من الحقيقة إلى المجاز }
$$

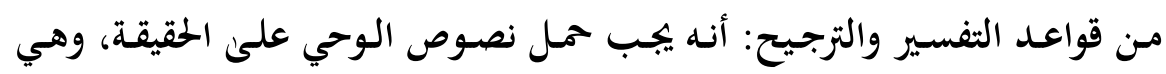

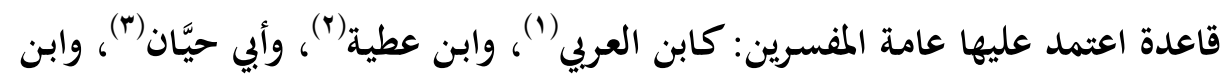

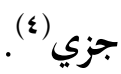

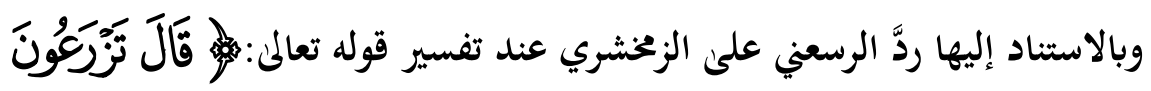

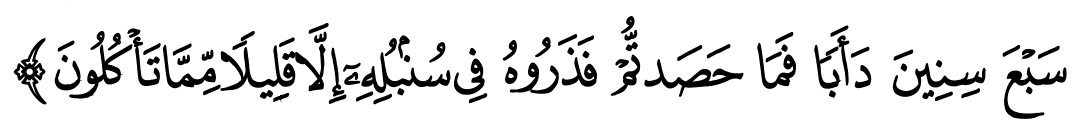

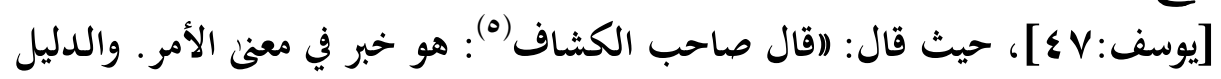

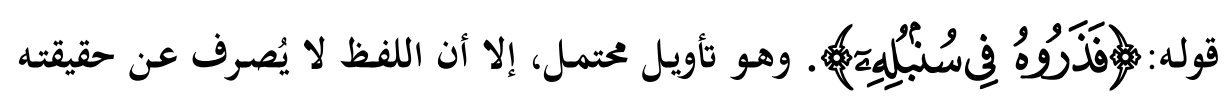

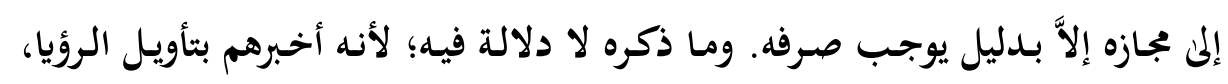

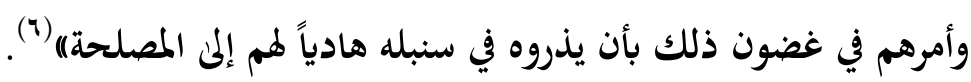

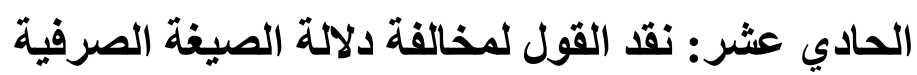
وهو أحد الأسس التي استند إليها الرسعني في رد بعض الألقالقيفة الصوال في تفسيره، ومثال

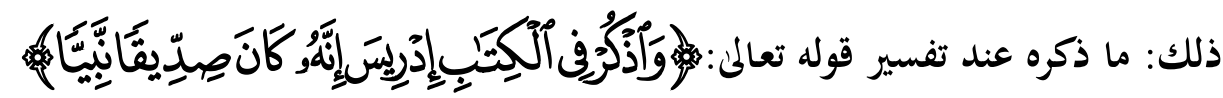

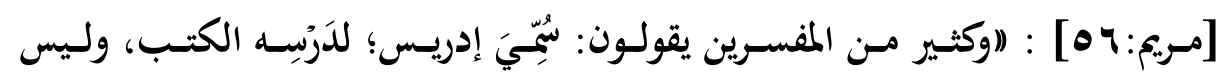

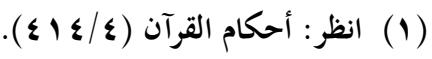

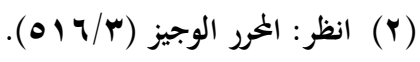

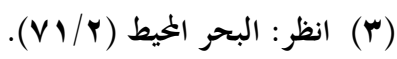

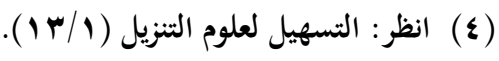

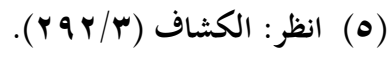

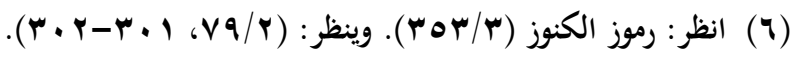


بصحيح؛ لأنه لو كان كذلك لكان إفعيلاً من الدَّرَّ، ولو كان كذلك لكان مُنْصَرِفاً؛

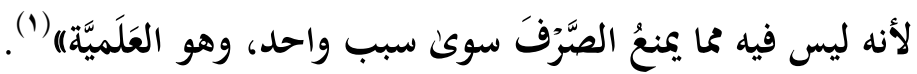
الثاني عشر: نقد القول لقدحه في عصمة الأنبياء

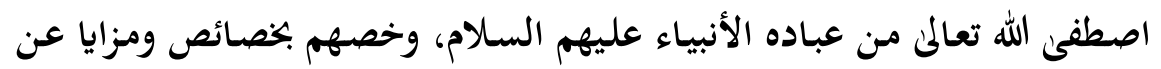

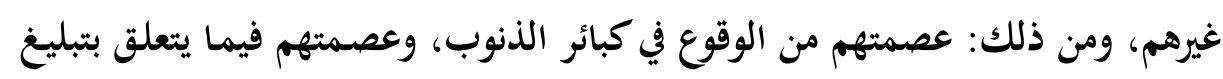

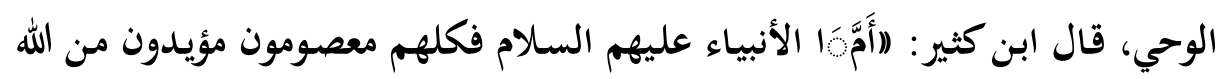

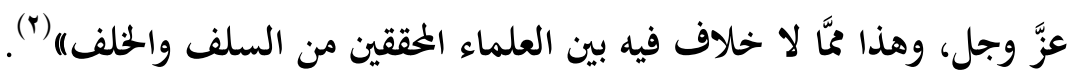

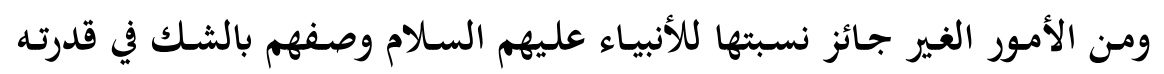

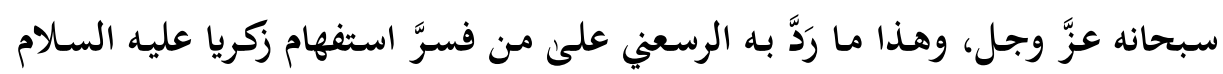

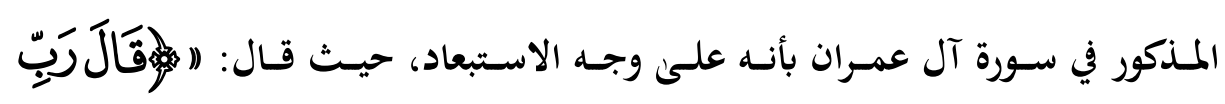

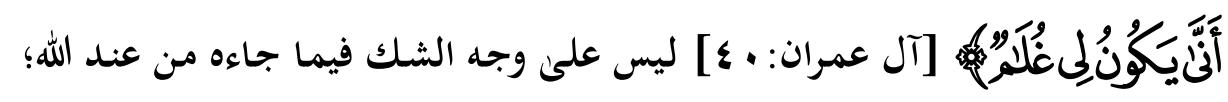
لأن الأنبياء معصومين من مثل هذه الحالة، ولا على وجه الاستبعاد كما زعم جماعة من

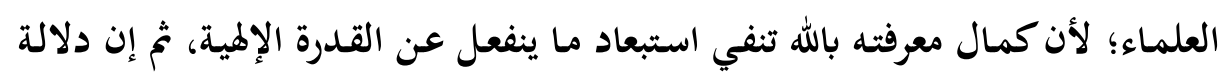

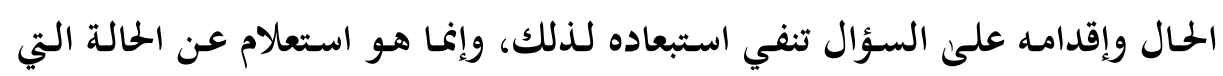

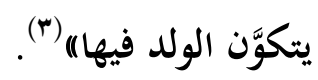
الثالث عشر: نقد القول لقدحه في مقام النبوة

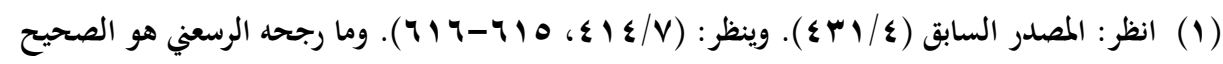
من قولي

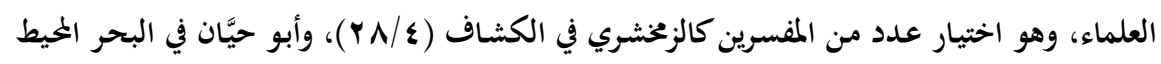




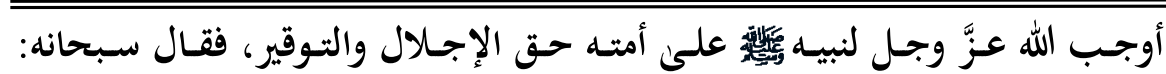

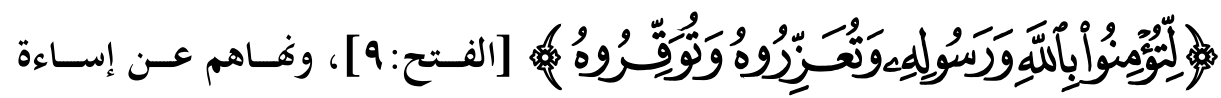

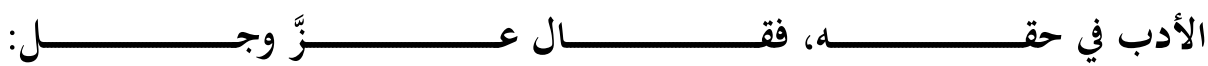

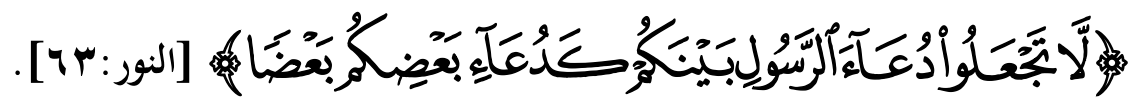

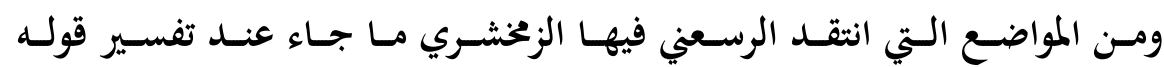

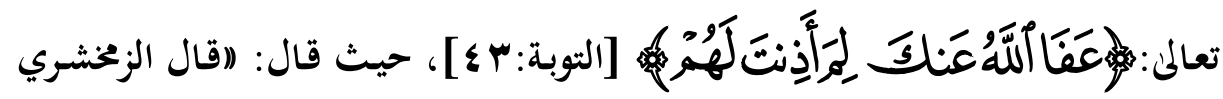

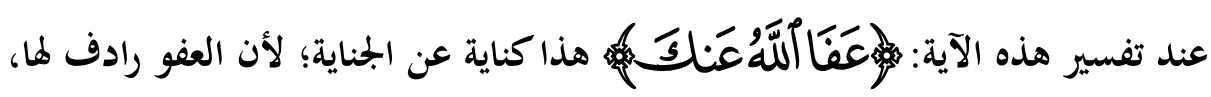
ومعناه: أخطأت وبئس ما فعلت (1). وهذا تغفيل من الزخشري عن اللطيفة المودعة في

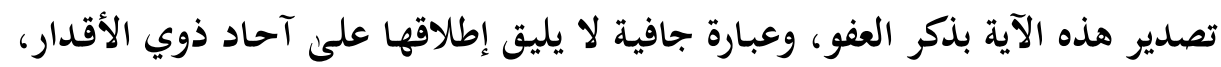

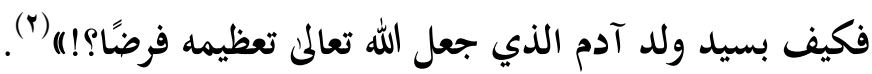
الرابع عشر: نقد القول لمخالفة العادة

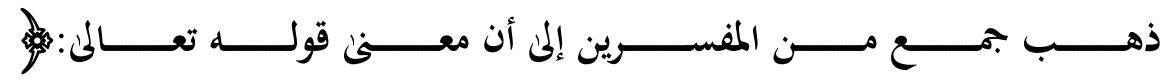

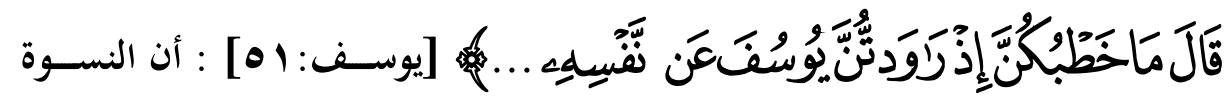
جميعهن يشتركن في مراودة يوسف عليه السلام، امرأة العزيز راودته بعينها، وبقية النسوة

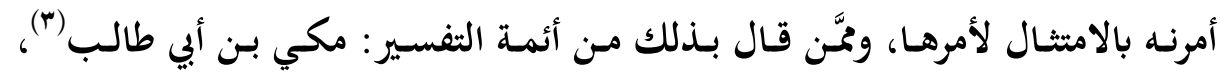

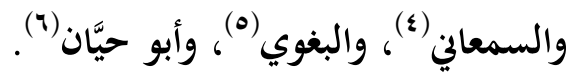

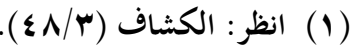

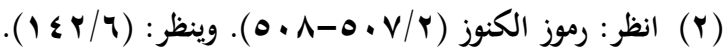

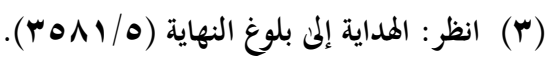

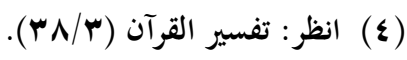

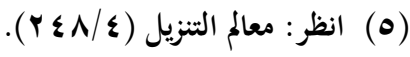

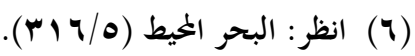


وهذا مـا اختـاره الرسعني، واستند في ردِّه على قول ابن الأنبـاري: أن الملكك أراد

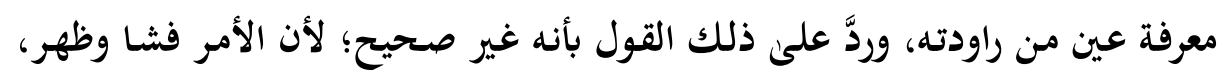

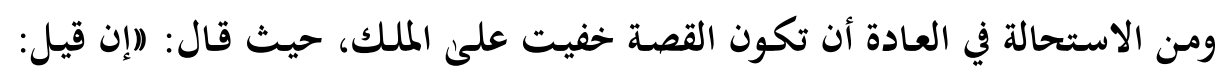

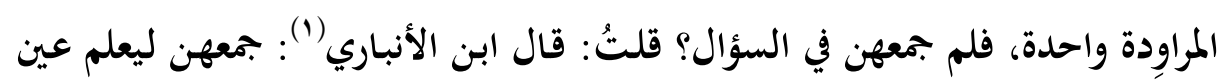

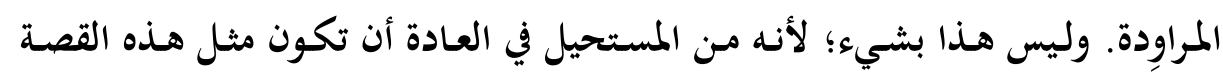

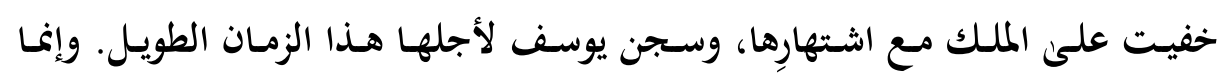

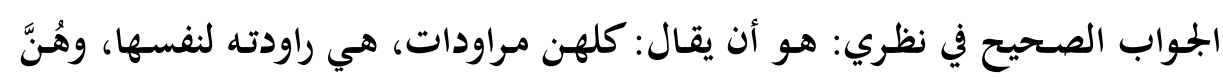

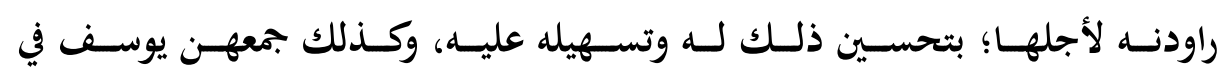

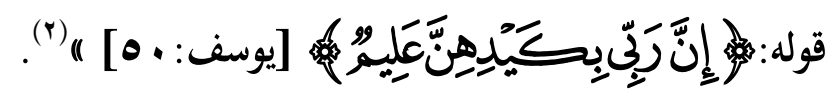

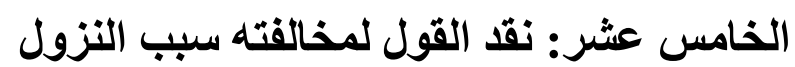

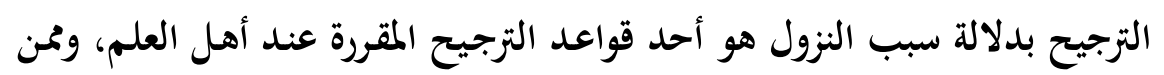

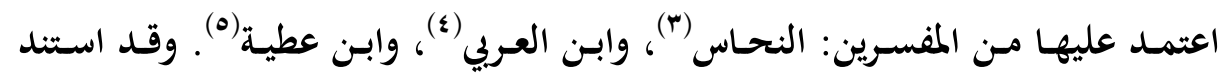

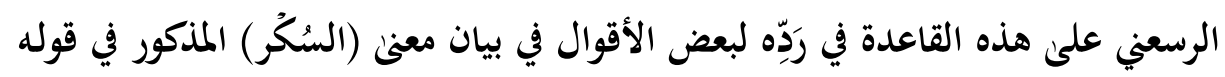

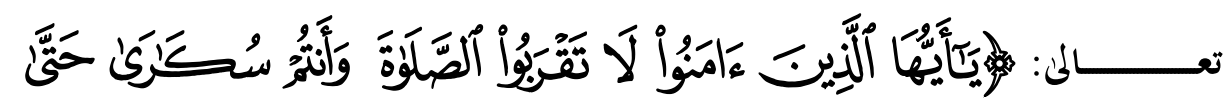

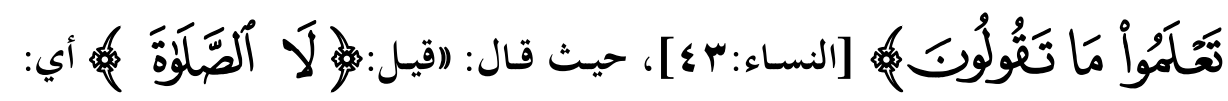

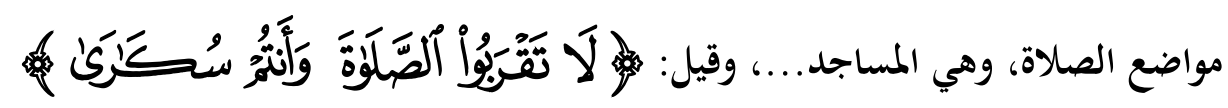

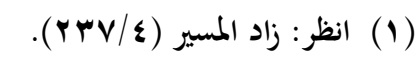

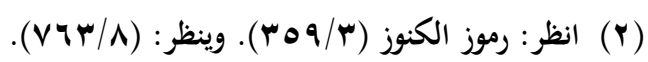

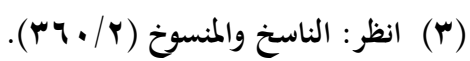

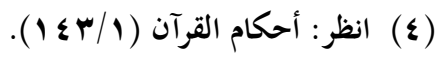

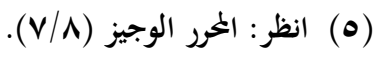




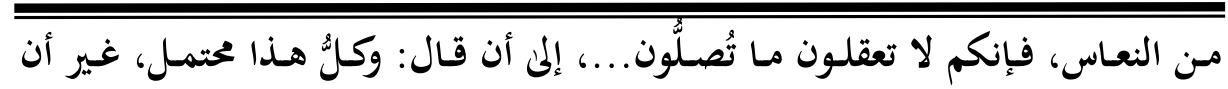
التفسير الذي يُعتمد عليه ما اقتضاه سبب النزول، وهو السُّكُر المعروفه" (1).

السادس عشر: نقد القول لكونه يُفضي إلى محال

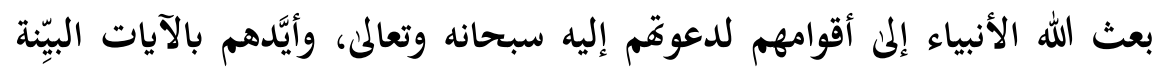

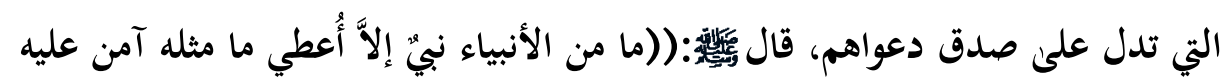
البشر، وإنَّا كان الذي أوتيتُ وحيًا أوحاه الله إليَّ، فأرجو أن أكون أكثرهم تابعًا يوم إنياء

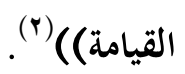

ومن هؤلاء الأنبياء المؤيدين بالآيات شعيب عليه السلام وهذا ما ذهب إليه جمهور

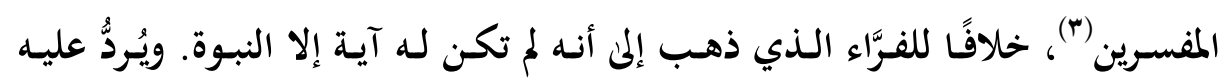

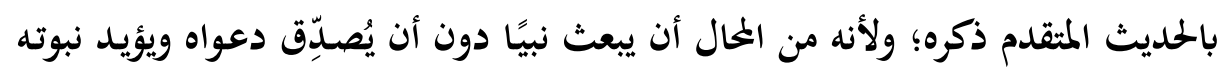
بآيةٍ من الآيات.

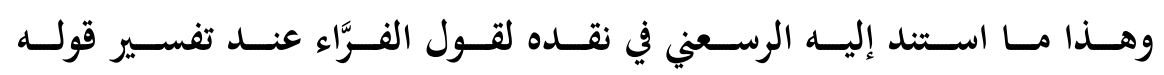

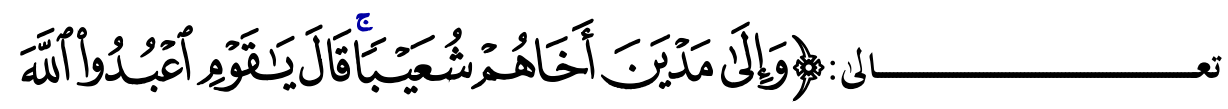

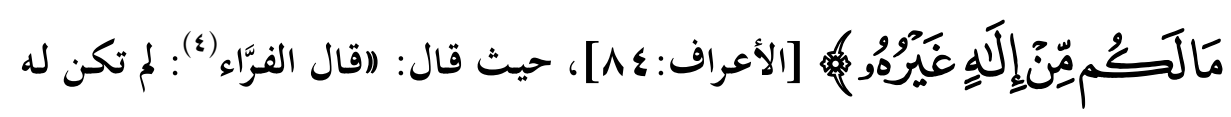
آية إلا النبوة. وليس هذا القول بشيء؛ لأنه يستلزم إيجاب التصديق والانقياد إلمى دعوى

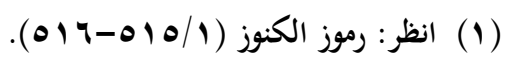

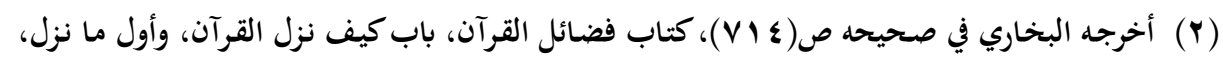

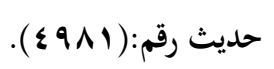

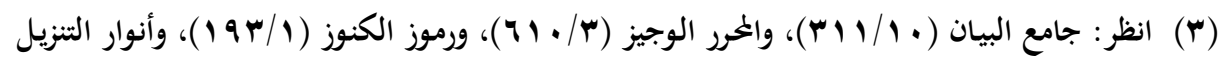

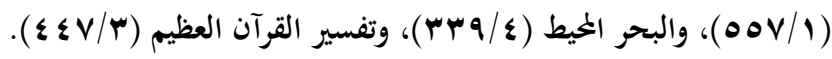

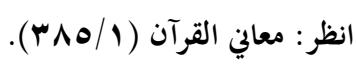


النبـوة مسن غـير بينـة أو شـاهد بصـحة الـدعوىن. ولأن ذلك يفضـ إلى التبـاس الحسق بالباطل. ولأنه يفضي إلمى محال، وما يفضي إلم المحال محاله" (1).

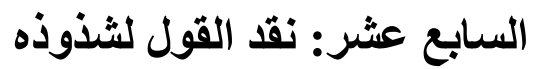
من قواعد التفسير والترجيح: أنه يجب مل مل كلام الله اله تعالم على المعروف من كلام

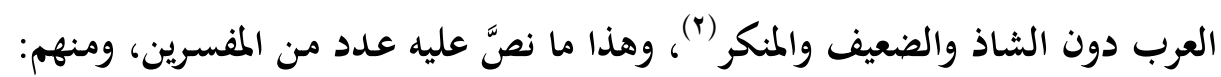

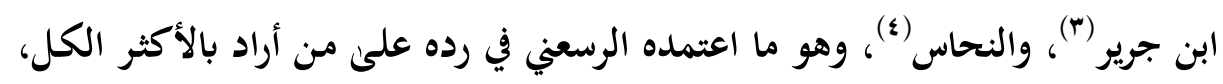

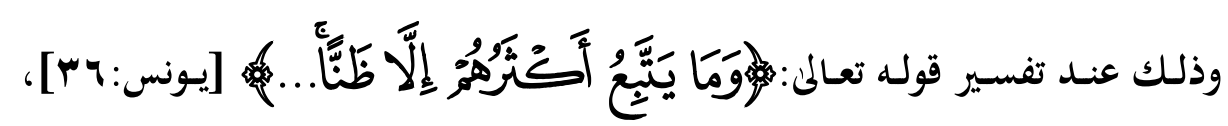
حيث قال: (اقال الثعلبي(0) والشيخ أبو الفرج ابن الجموزي()) وكثير من العلماء: المراد بالأكثر: الكل، وقالوا: المعنن: وما يتبعون إلا الظن في قولمم أفا آلهة. والقولان بعيدان،

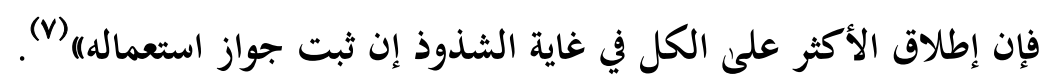

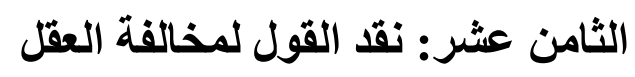
وهو أحد الأسس التي استند عليها الرسعني في رده على الأقوال الباطلة، ومثال

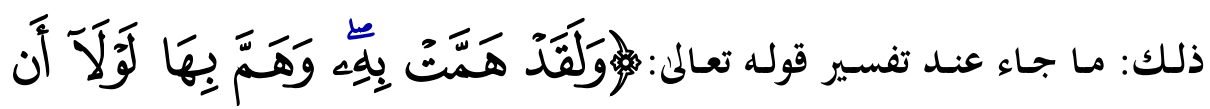

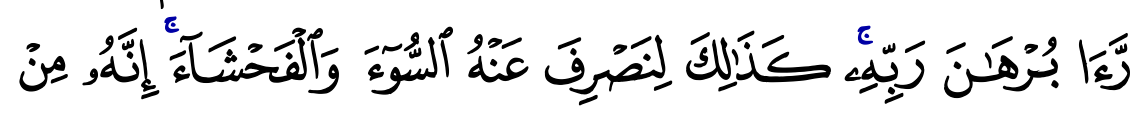

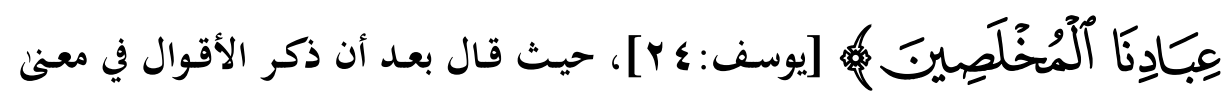
الآية: الوالذي عليه جمهور أهل المعاني والنظر الصحيح: أن البرهان الذي رآه زواجر

$$
\begin{aligned}
& \text { (1) انظر: رموز الكنوز (1) (1) (1) (1). }
\end{aligned}
$$

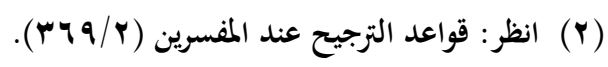

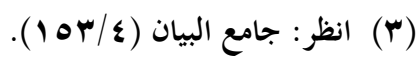

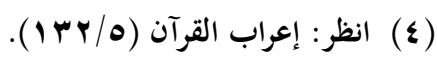

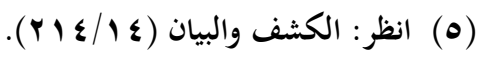

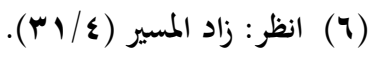

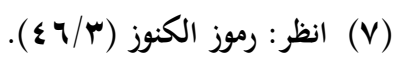


العقل والدين والحجج المأخوذة على المكلفين من اجتناب الححارم. وقد نقلوا في تفسير

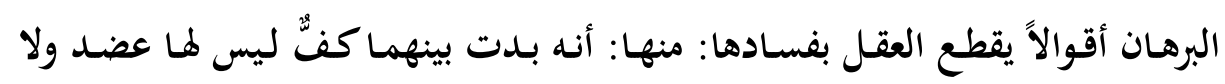

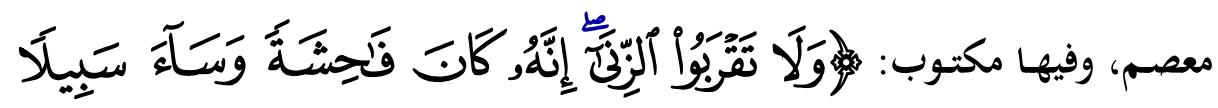

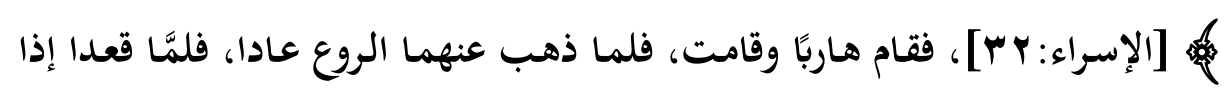

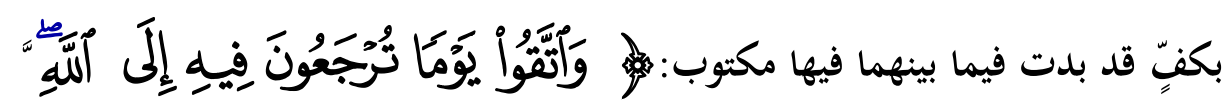

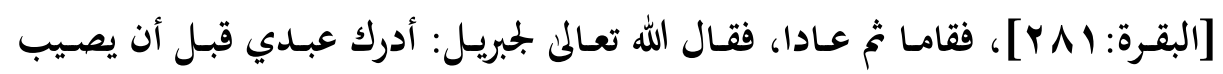

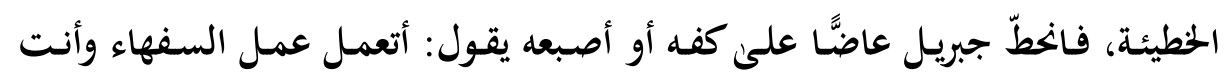

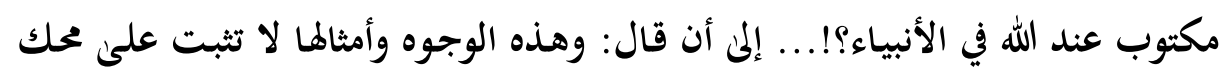

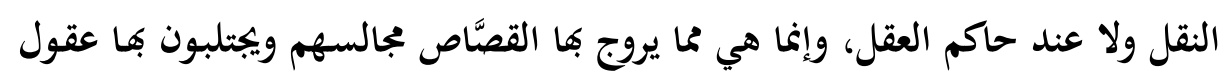
العامة، وليست من الصحة والتحقيق في شيء"|(1).

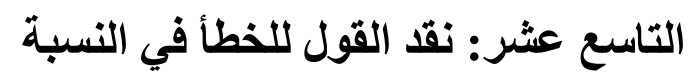
من الأسس التي استند إليها الرسعني في نقده: الحطأ في نسبة القراءة، ومثاله: ما جاء

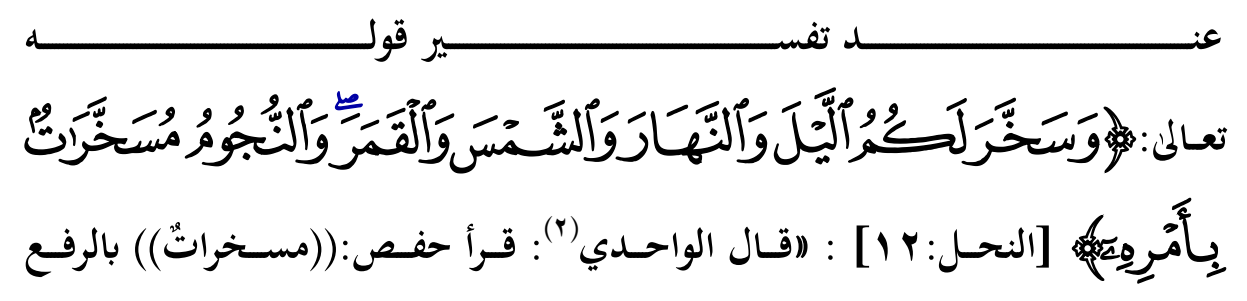


وحسدها(1)، وجعلها خـبر ابتـداء محذوف، كأنه قال: هي مسـخرات. وهـذا سـهو، فإن حفصًا قرأ:((والنجومُ)) بالرفع على الابتداء، ((مسخرات)) خبره)|(r). العشرون: نقد القول لاستشهاده بحديث ضعيف الإسناد

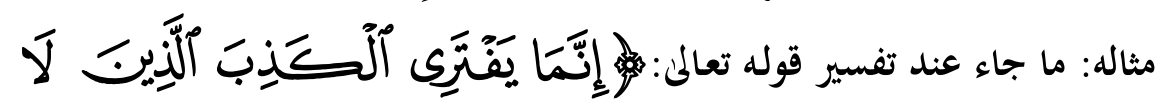

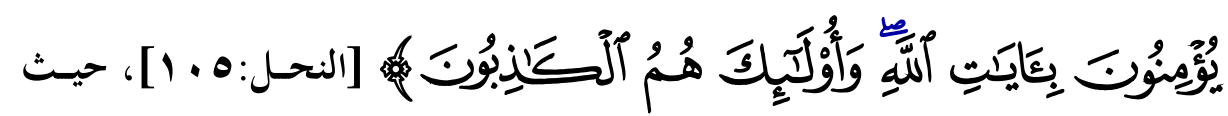
قال: (اوقد روىن الثعلبي(؟) والواحدي(؛) بإسنادهما عن يعلى بن الأشدق، عن عبدالله بن جراد قال: (اقلت: يا رسول الله! المؤمن يزبي؟ قال: قد يكون ذلك. قال: قلت: يا رسـول الله! المـؤمن يسـرق؟ قـال: قـد يكـون ذلك، قـال: قلـت: يا رسـول الله! المـؤمن

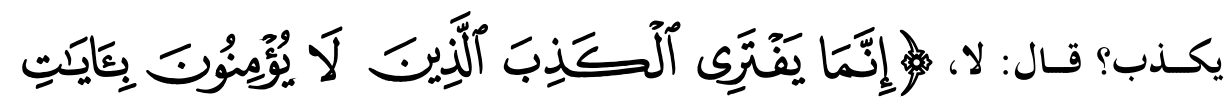

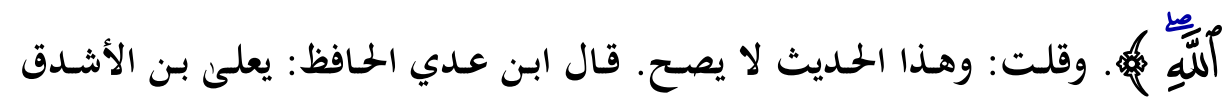
وعمه عبد الله بن جراد غير معروفين، وعبدالله بن جراد لا تثبت صحبته)|"(ه).

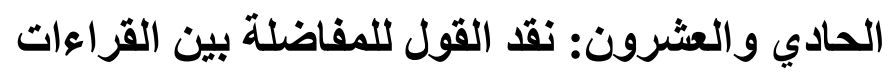
من القواعد المقررة عند أهل العلم: أن القراءة القرآنية إذا ثبتت فلا يجوز ردها أو رد معناها(7)، خلافًا لصنيع بعض المفسرين والمُعربين الذين ردوا بعض القراءات الثابتة بحُجَّة مخالفة أحد القواعد النحوية أو الوجوه الإعرابية، وهذا ما أكدَّ على خطأه غير واحد من

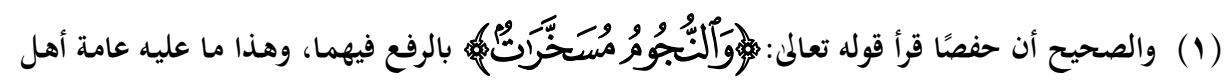

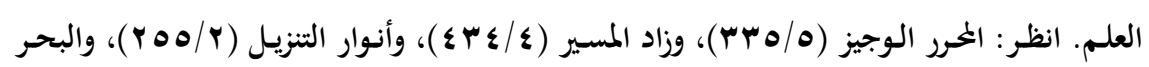

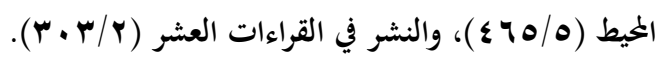

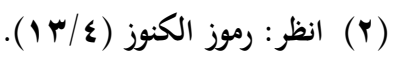

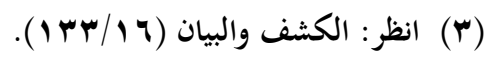

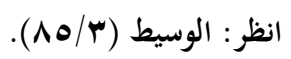

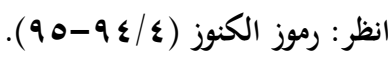
ينظر: قواعد الترجيح عند المفسرين (1/ (1) ). 
أهل العلم، من ذلك: ما قاله أبو عمرو الداني: (اوأئمة القراءة لا تعمل في شيء من حروف القرآن على الأفشى في اللغة، والأقيس في العربية، بل على الأثبت في الأثر ،

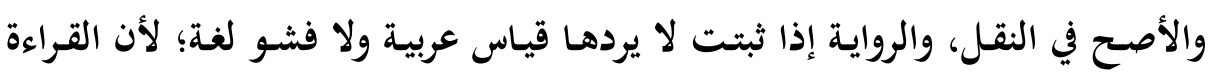
سُنَّة متبعة يلزم قبولها والمصير إليها)|(1). وقد ردَّ الرسعني على الزجاج مفاضلته بين القراءات الثابتة، وذلك عند تفسير قوله

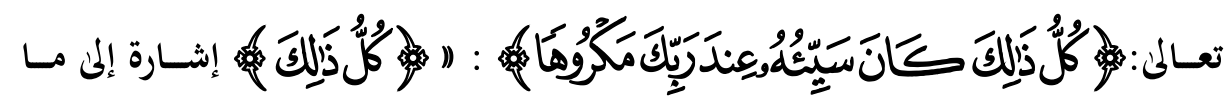

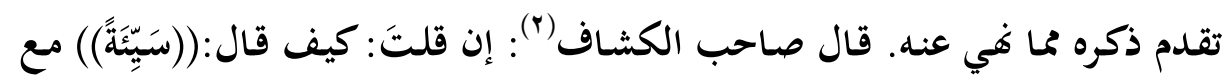

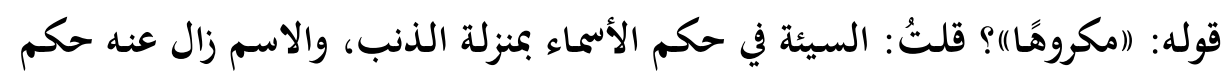

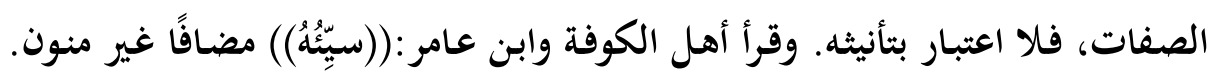

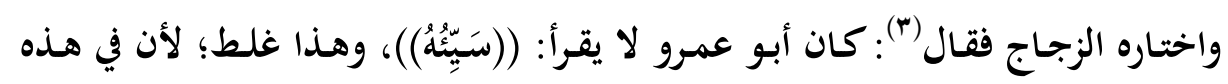

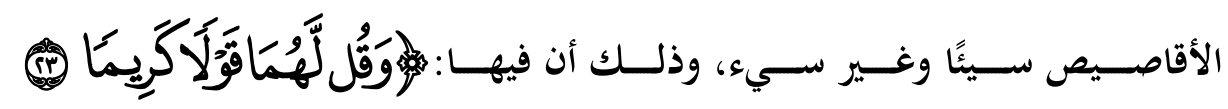

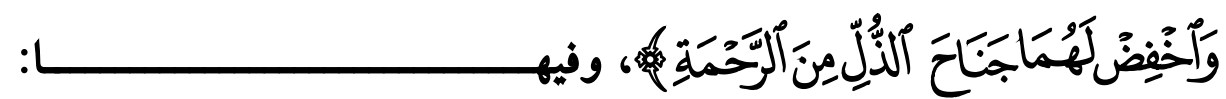

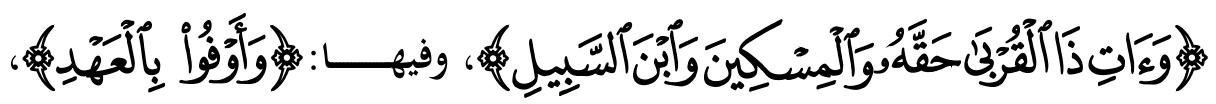

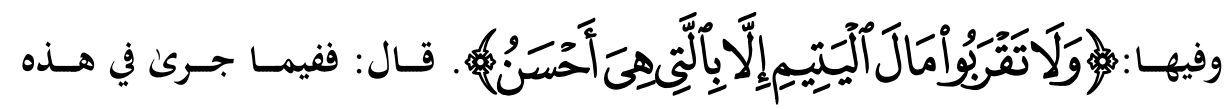

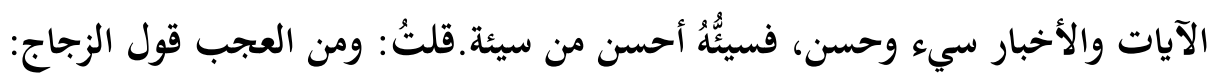
هذا غلط، وهي قراءة أهل الحجاز وأهل البصرة بناء على ما ذكره من فئل التعليل، مع أنه

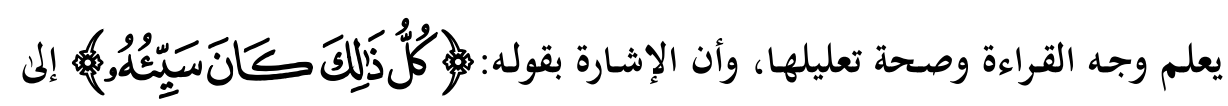
ما تقدم ذكره مما فهى الله عنه)|"(

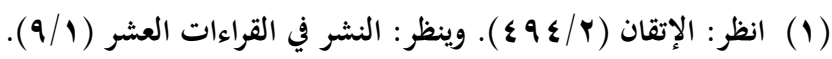

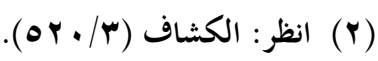

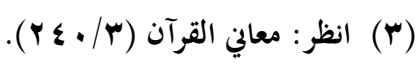

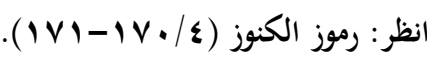




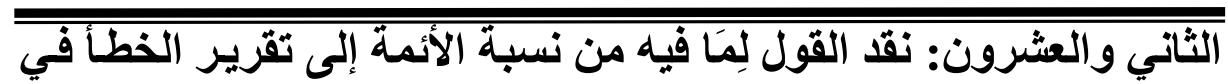
القرآن

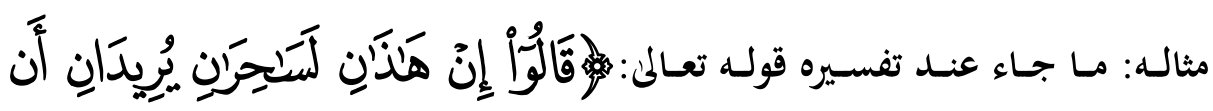

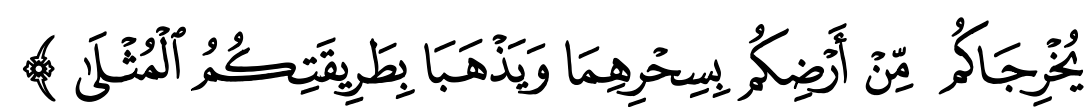

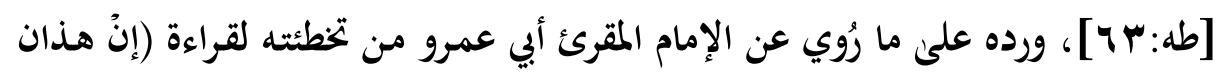

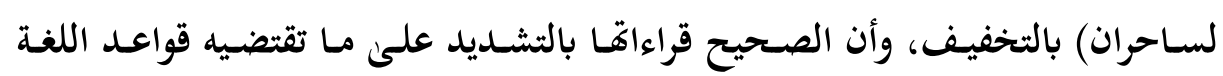

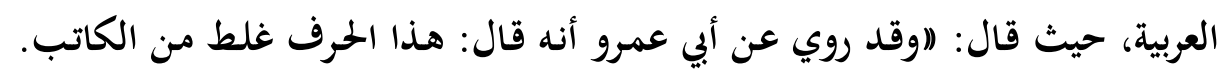

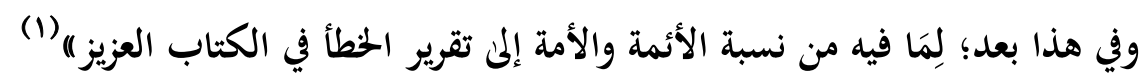

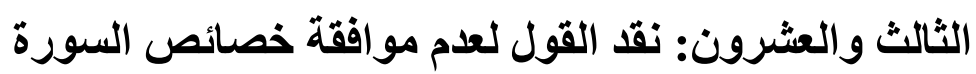

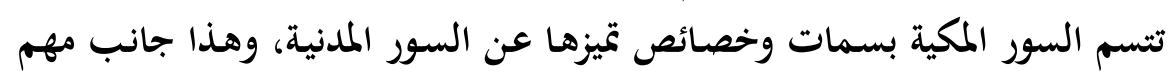

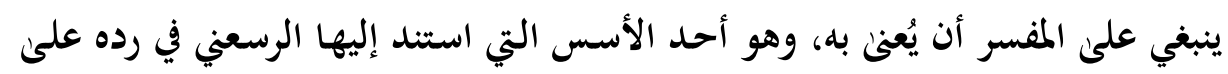

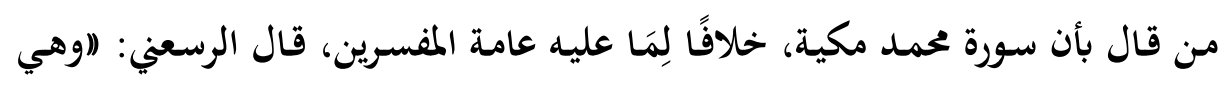

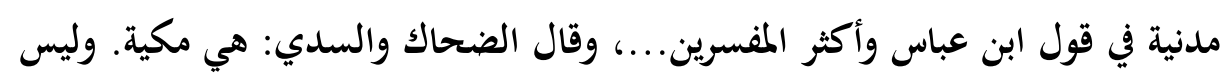

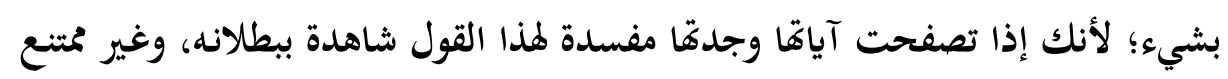
أن تشتمل على آيات مكية، لكن إطلاق القول بنزولها كلها بمكة خطأ) (؟). الرابع والعشرون: نقد القول لعدم وجاهته إنه

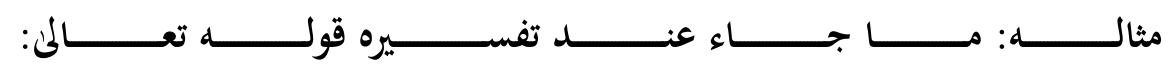
男

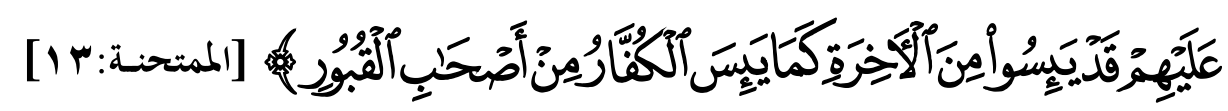
بقوله: (افِان قيل: ما تقول في قول الثعلبي (َ): كما يئس الكفار من أصحاب القبور أن 
يرجعوا إليهم؟ قلتُ: ليس بمستقيم؛ لأن المؤمنين والكفار مشتركون في اليأس من رجوع أصحاب القبور إليهم (1)، فيكون الاقتصار على ذكر الكفار عديم التأثير") (Y).

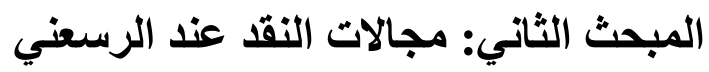

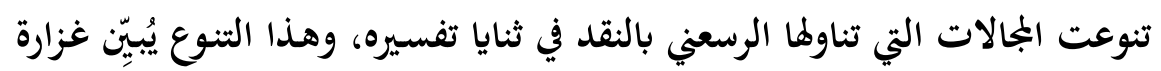

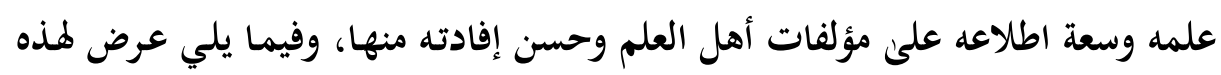
الجالات التي تطرق لما في تفسيره، وهي كالآتي:

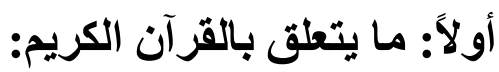
أ- نقد القول لمخالفة دلالة السياق، وذلك من الفران الكرئ خلال الأسباب التالية: 1- نقد القول لمخالفة الموضوع(؟).

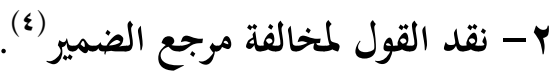
ب- نقد القول لمخالفة سياق ولحاق الآية (ه). ب- نقد القول لمخالفة ظاهر القرآن(؟). ج- نقد القول لمخالفة دلالة آية أخرى (v). د- نقد القول لصرف اللفظ من الحقيقة إلم الجماز (^).

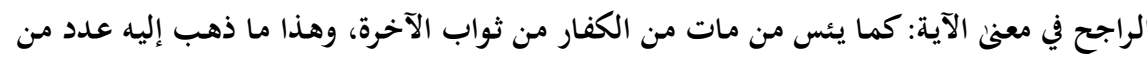

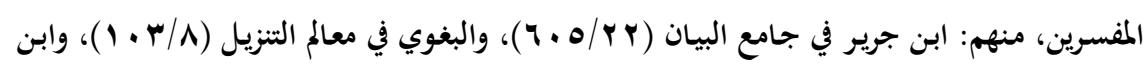

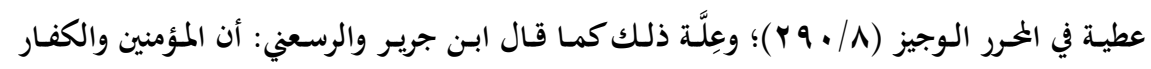

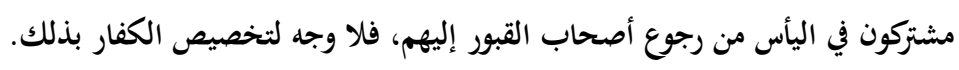

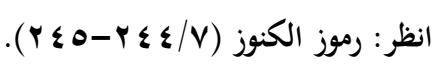

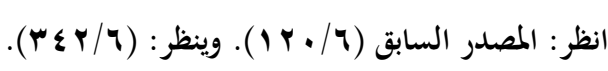

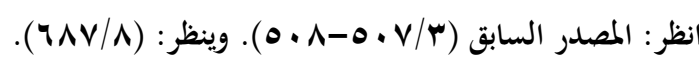

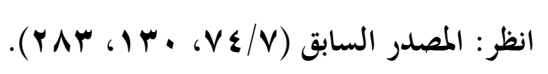

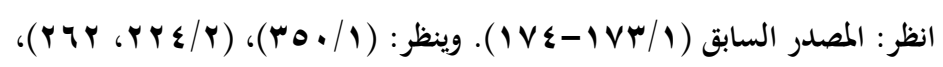

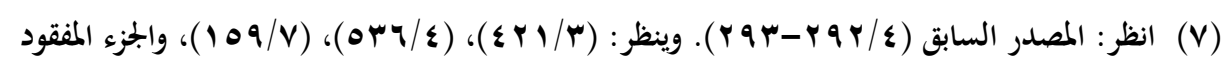


هـ- نقد القول لمخالفة تاريخ النزول(1).

و - نقد القول لمخالفة سبب النزول(r).

ز- نقد القول لمفاضلته بين القراءات(r).

ح- نقد القول لما فيه من نسبة الأئمة إلى تقرير الحخأ في القرآن الكريم (ء).

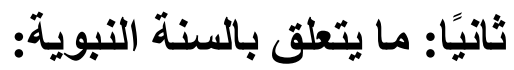
أ- نقد القول لمخالفة الحديث الصحيح (•).

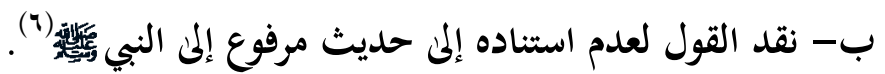
ج- نقد القول لاستشهاده بحديث ضعيف الإسناد (v).

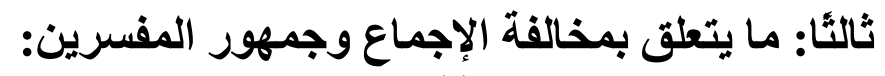
أ- نقد القول لمخالفة الإجماع(^). ب- نقد القول لمخالفة جمهور المفسرين(9). رابعًا: ما يتعلق بمخالفة عقيدة أهل السنة والجماعة:

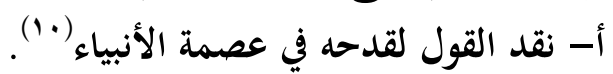

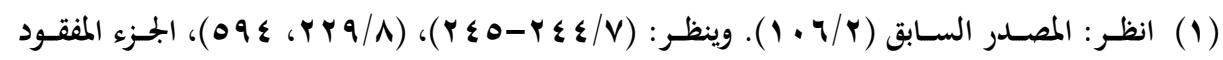
ص) (OV9)

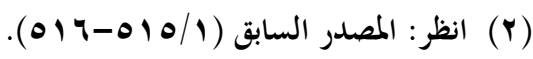

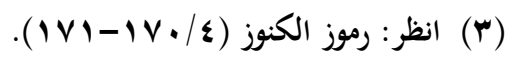

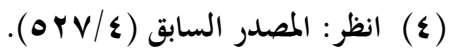

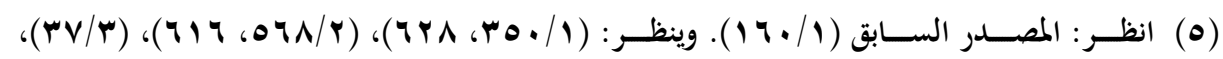

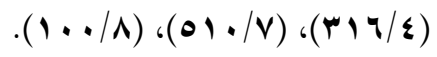

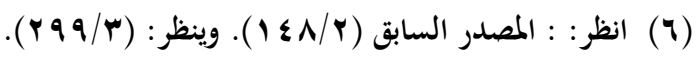

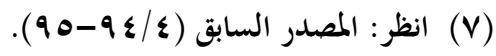

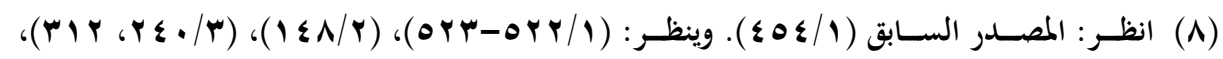

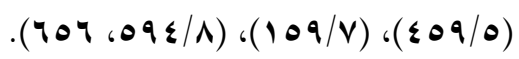

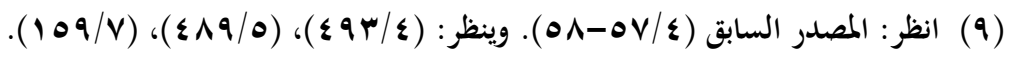

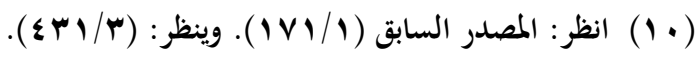


ب- نقد القول لقدحه في مقام النبوة(').

ج- نقد قول المعتزلة باستحالة رؤية الله عزَّ وجل (؟).

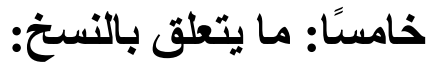

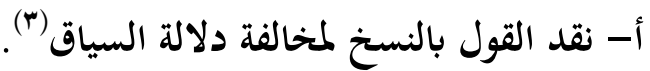

ب- نقد القول بالنسخ لأن الآية من باب الأخبار، والأخبار لا تنسخ (\&).

ج- نقد القول بالنسخ لأن الآية من العام المراد به الخصوص (ه).

د- نقد القول بالنسخ لإمكانية الجمع بين الآيتين(").

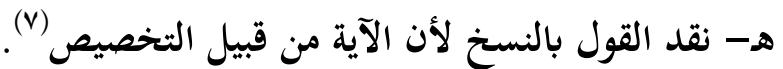

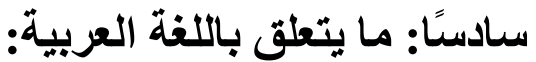

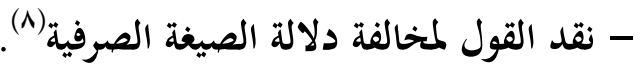
سابعًا: ما يتعلق بمخالفة العقل والعادة:

أ- نقد القول لمخالفة العقل (9).

ب- نقد القول لمخالفة العادة(·').

*s

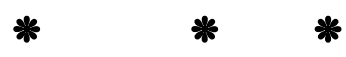

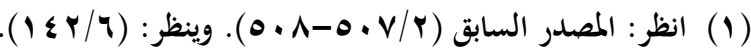

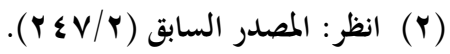

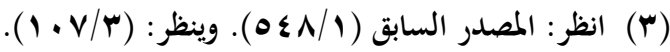

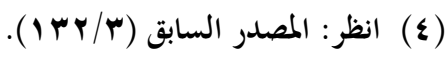

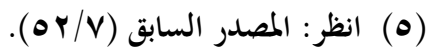

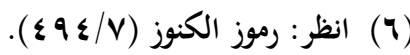

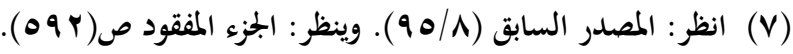

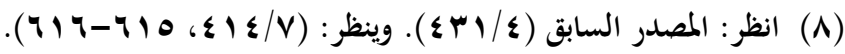

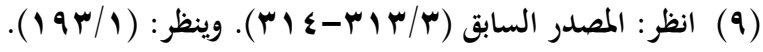

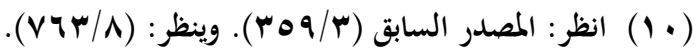




\section{الخاتمــة}

وبعد هذا العرض الموجز لمعالم المنهج النقدي في تفسير الإمام الرسعني يحسن

أن أذكر في خاتمته أهم نتائج البحث وتوصياته. النتائج:

أولاً: أن النقد علم له أصوله وضوابطه وأساليبه، وهو يحتاج من الباحثين إلى دقة وصبر، وحسن فهم لمناهج وأقوال من يتوجه إليهم النقد؛ حتن يكون النقد بنَّاءً وإيجابيًا، وملتزمًا

$$
\text { بالأسس والمقومات العلمية. }
$$

ثانيًا: أفاد الرسعني في تفسيره من عدد من المصادر المتنوعة، إلاً أنه لم يكن عجرد ناقل

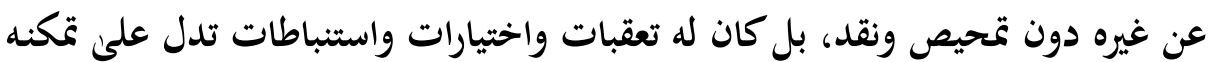
ورسوخه العلمي؛ وهذا ما جعل كتابه أحد المراجع المهمة في علم التفسير.

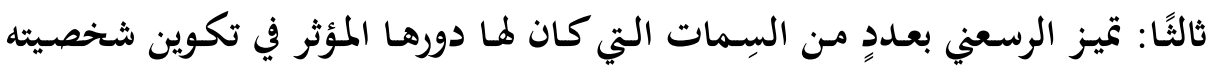


رابعَا: تبـاين أسـلوب الرسعني في نقـده فتـارةً ينقـــ القـول ويعـزوه لقائلـه دون أن يُبسيَّن

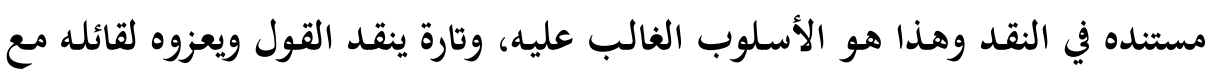
بيانه لمستنده في النقد، وهذا الأسلوب أقل من سابقه.

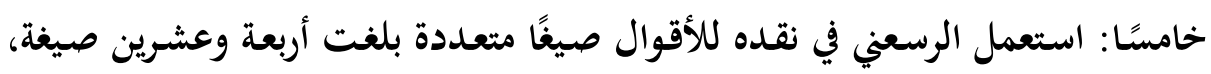

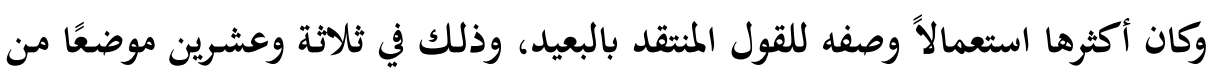
تفسيره. سادسًا: تعقب الإمام الرسعني بالنقد عددًا من أهل العلم إلاًّ أن أكثر من تعقبه وناقشه

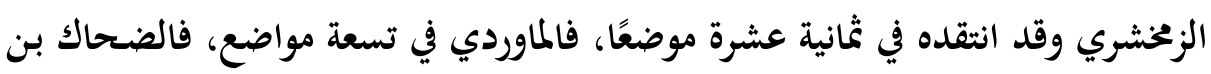
مزاحم، ومقاتل بن سليمان، والواحدي في سبعة مواضع.

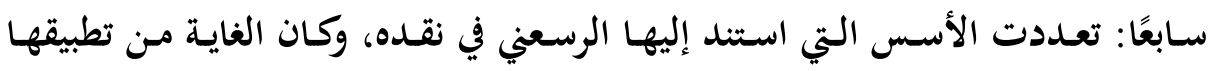
وحسن توظيفها تحرير الأقوال لتمييز المقبول من المردود، وهذا مسلك أهل التحرير والتحقيق، وهو السبيل الذي ينبغي أن يسلكه الباحثون.

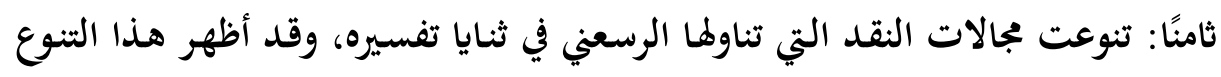
غزارة علمه ودقة فهمه وشموليته في النقد. تنوعن تاسعًا: إن دراسة مجالات النقد والنظر فيها بنظرة فاحصة ومتأملة يُكسب فئمس الباحث معرفة بالجوانب التي لها صلة بعلم التفسير، ويرشده إلى طرائق أهل العلم في نقدهم للأقوال

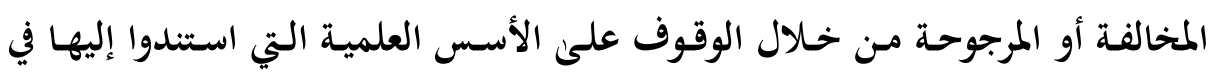
نقدهم.

التوصيات:

1- يوصي الباحث طلاب العلم بأهمية العناية بتفسير الرسعني، فهو تفسير قِّم ومحرَّر، وحافل بالفوائد والفرائد. 
Y - توجيه الباحثين المتخصصين إلمى التأمل في معالم المنهج النقدي في التفسير من خلال

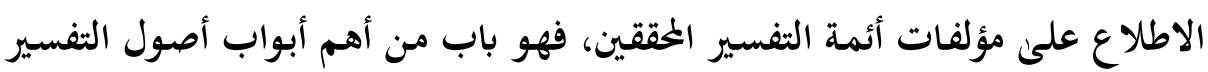
التي لها ضوابطها وأسسها، ولا يزال بحاجة إلى إعطاءه مزيدًا من البحث والدراسة. ب- دراسة توجيه القراءات في تفسير الرسعني. ع - دراسة توجيه أقوال المفسرين عند الرسعني.

والحمد لله الذي بنعمته تتم الصالحات، وصلى الله وسلم على نبينا محمد، وعلى آله وصحبه أجمعين.

*

*

* $\quad *$

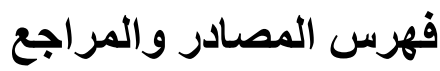

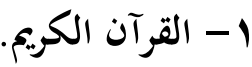

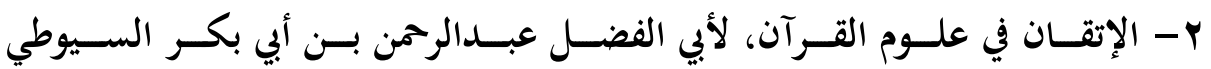

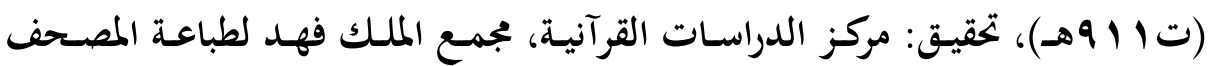

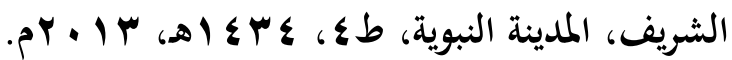

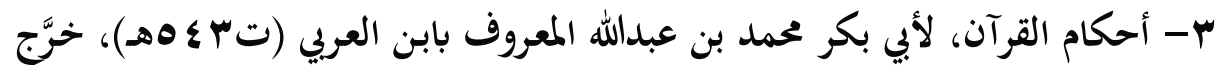

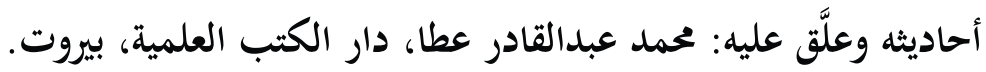

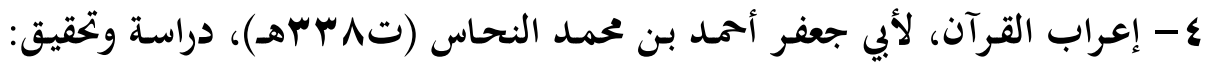

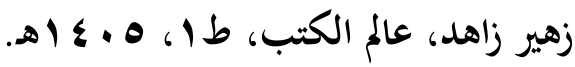
ه- الأعلام، لحير الدين الزركلي (ته 9 ب اهـ)، دار العلم للملايين، بيروت، طه، 
ج- أنوار الننزيل وأسرار التأويل= تفسير البيضاوي، لأبي الحخير عبدالله بن عمر بن محمد

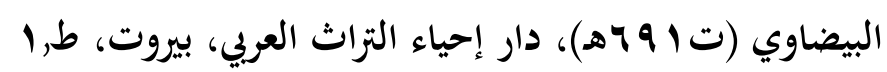

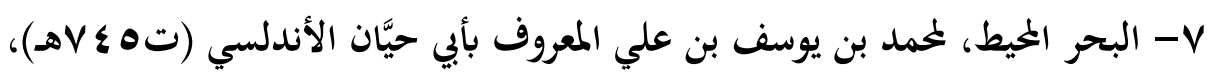

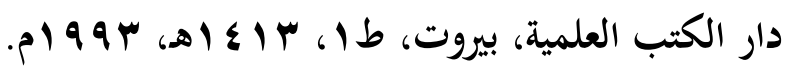

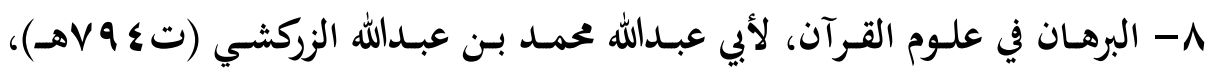

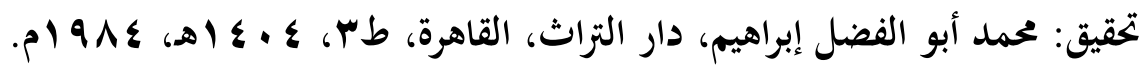

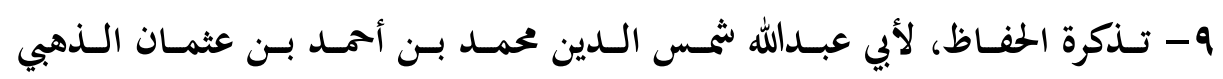
(تA \& Vه)، دار إحياء التراث العربي، بيروت.

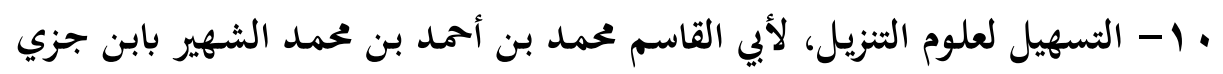

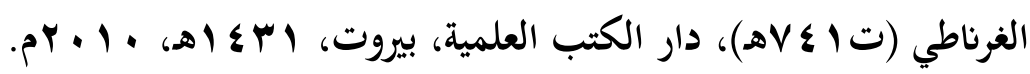

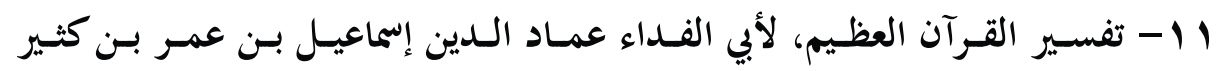

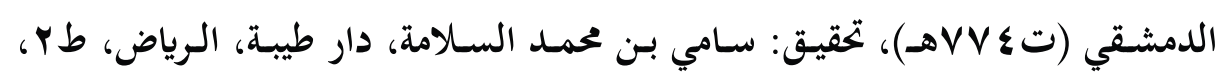

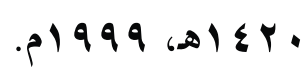
r ا - تفسـير القـرآن، لأبي المظفـر منصـور بــن محمـد التميمسي المعـروف بالسـمعالي

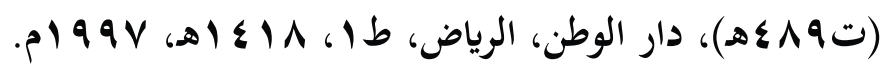

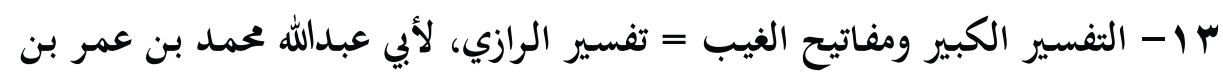

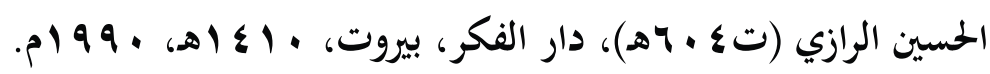

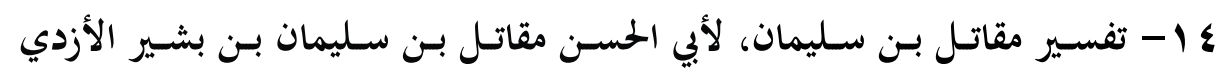

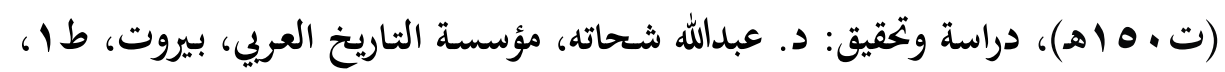

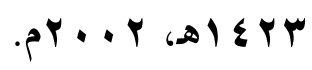
10

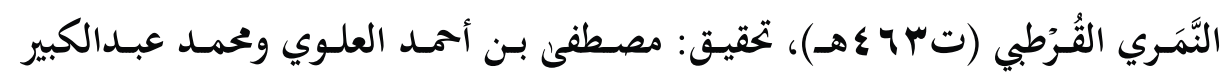

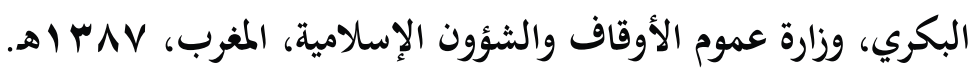


19

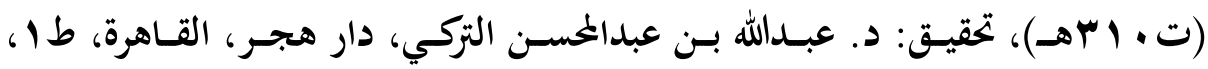
.PY.. I I I \&Y IV - الجحامع لأحكام القرآن والمُبَيِّن لما تضـمنه مـن السـنة وآي الفرقان، لأبي عبدالله

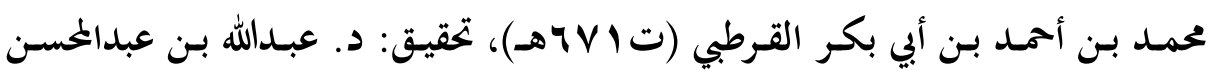

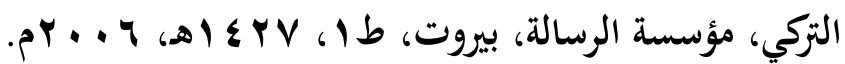

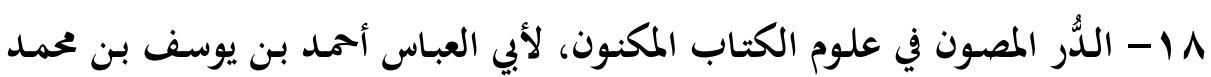

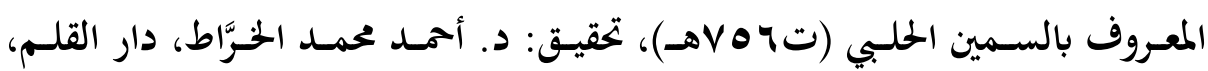
دمشق.

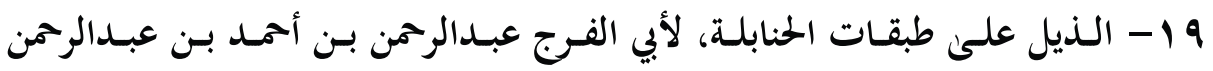
المعروف بابن رجب الحنبلي (ته 9 Qهـ)، تحقيق وتعليق: د. عبدالرحمن بـن سليمان

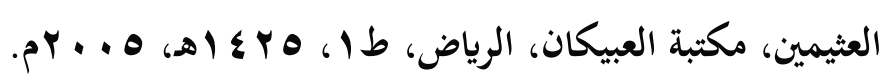

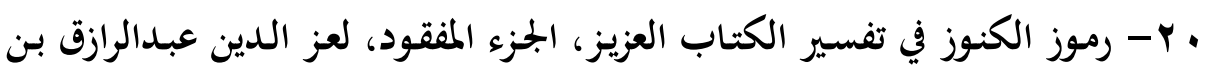

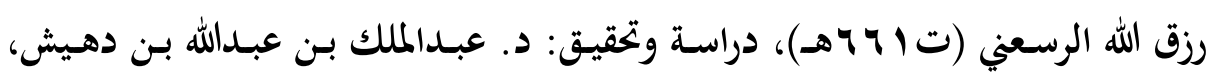

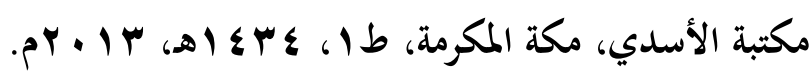
ا (- رموز الكنوز في تفسير الكتاب العزيز، لعز الدين عبدالرازق بن رزق الله الرسعني

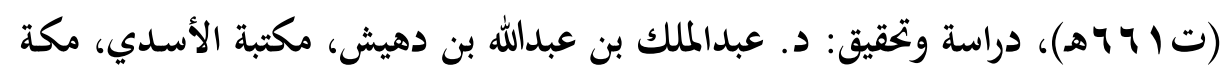

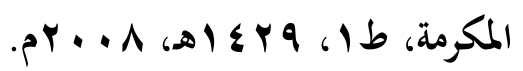

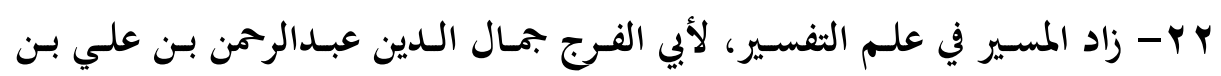

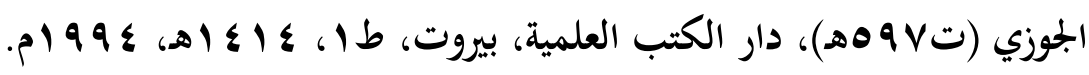

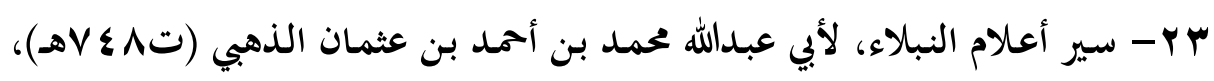

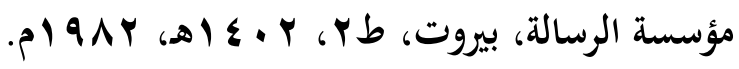


ع Y - شـذرات الذهب في أخبار من ذهب، لأبي الفلاح عبدالحي بـن أمـد بـ محمد

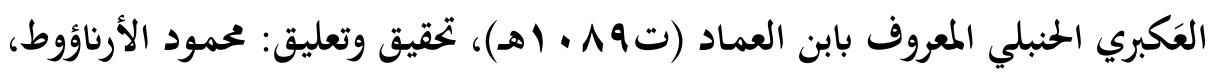

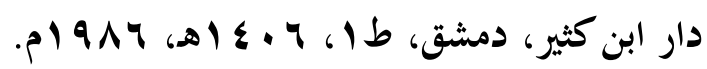

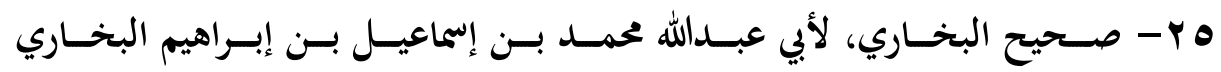

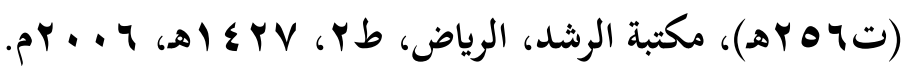

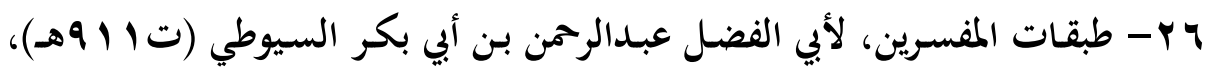

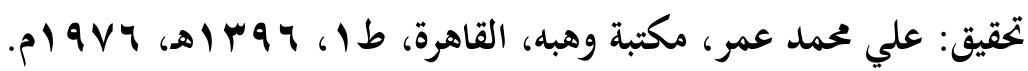

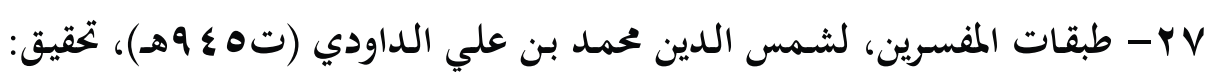

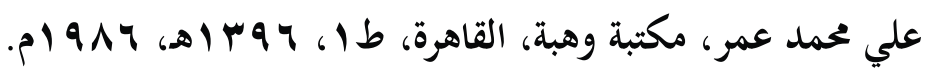

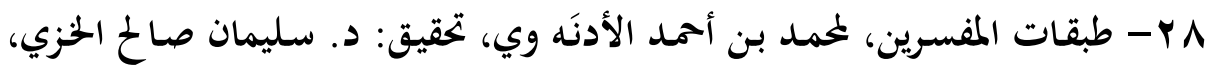

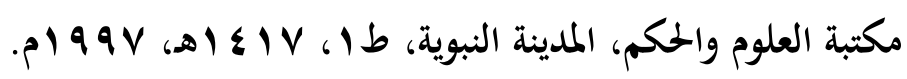

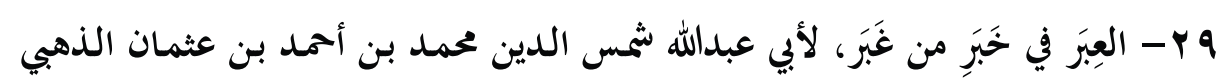

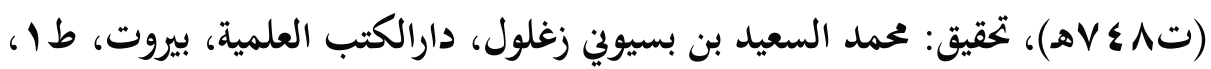

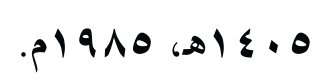

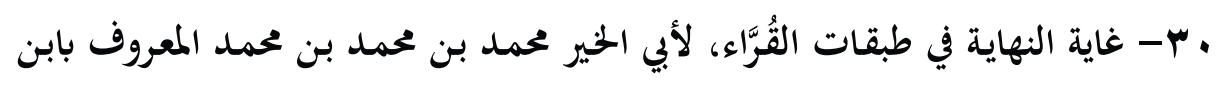

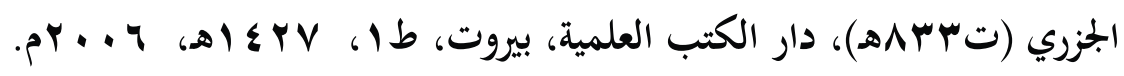
اس - قواعد الترجيح عند المفسرين، د. حسين بن علي الحربي، دار القاسم، الرياض،

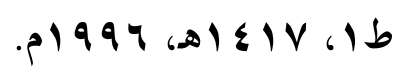

ץ ب- الكشــاف عـن غوامض التنزيل وعيون الأقاويل في وجـوه التأويـل، لأبي القاسم

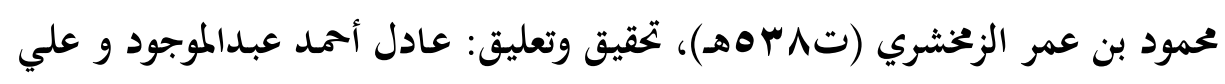

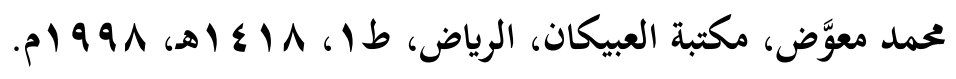

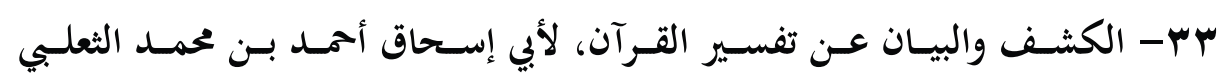

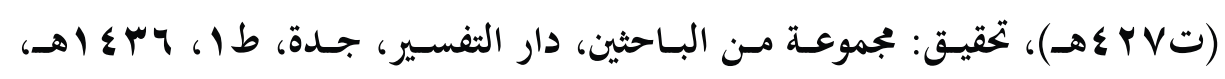


\& Y- لسان العرب، لأبي الفضل جمال الدين ابن منظور الإفيقي (ت I I I)، دار

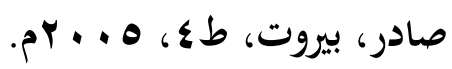

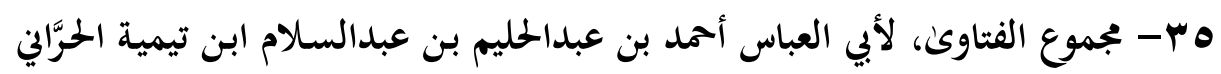

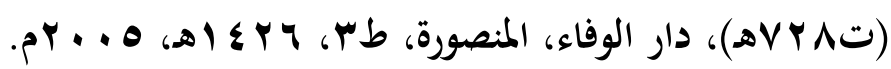

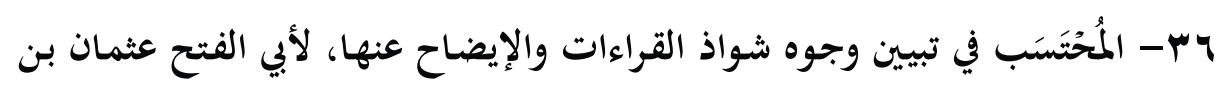

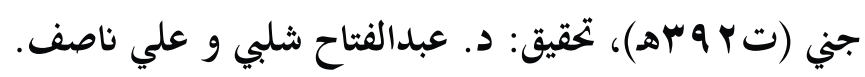

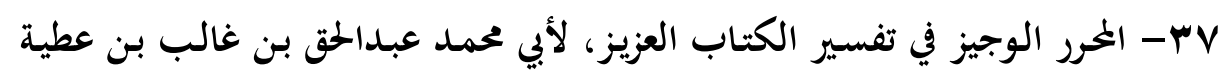

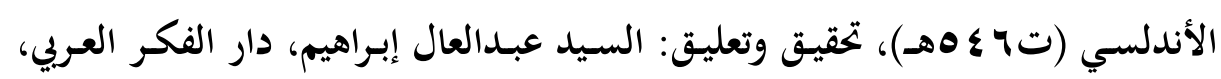

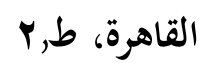

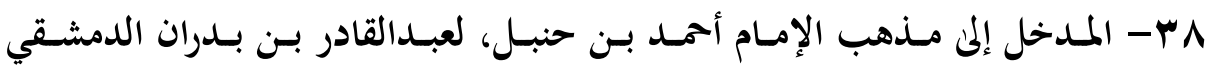

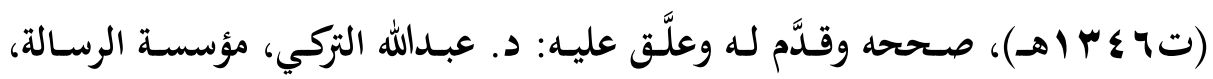

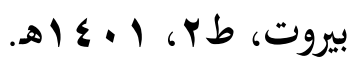
q ب- المستصفىى مـن علم الأصـول، لأبي حامـد محمد بـن محمـد الغزالي (ته ـ مهـ)، دراسة وتحقيق: د. حمزه بن زهير حافظ.

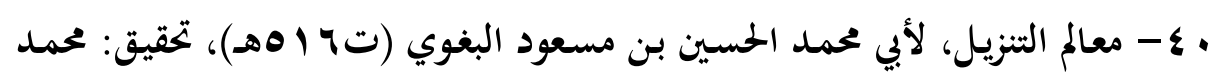

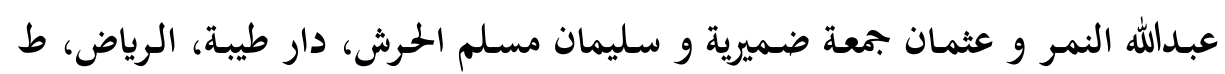
r إله

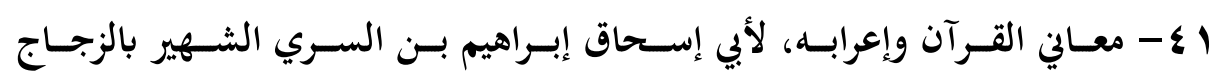

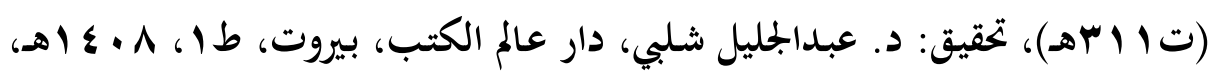
. 9 १ᄉ Y צ - معجم البلدان، لأبي عبدالله ياقوت بن عبدالله الحموي الرومي (ت ب ب جهـ)، دار

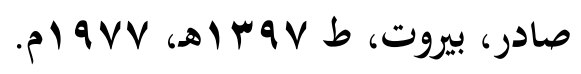

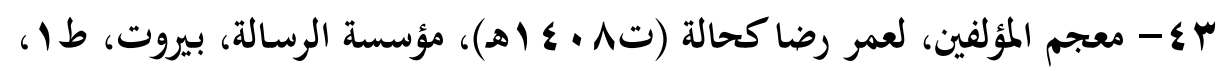


؟ ـ - الموافقات في أصول الشريعة، لأبي إسحاق الشاطبي إبراهيم بن موسى اللَّخمي

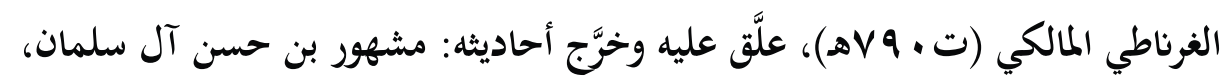

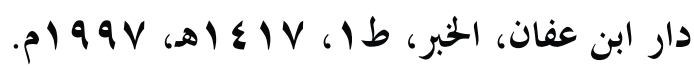

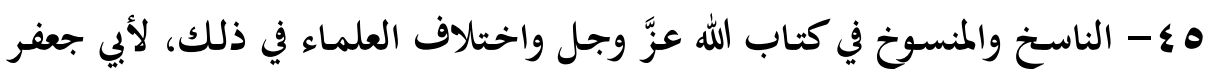

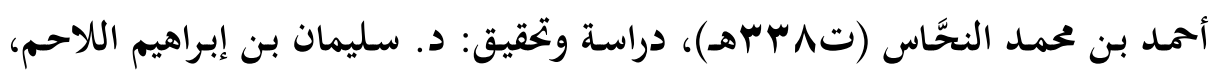

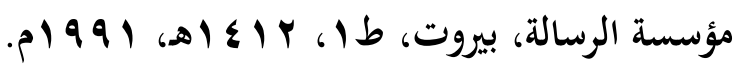

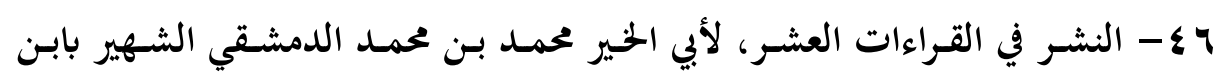
الجزري (تش \& V

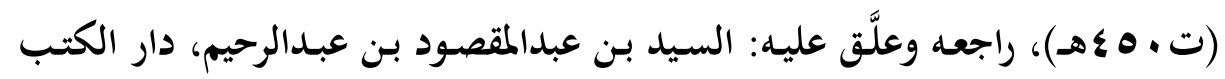

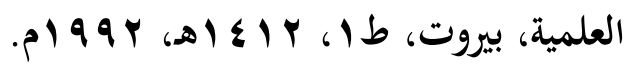

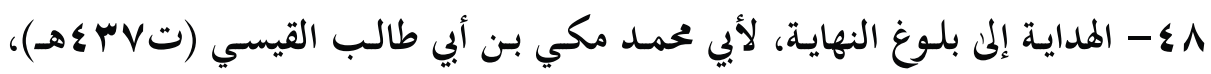
دراسة وتحقيق مجموعة من الباحثين، من إصدارات جامعة الشارقة.

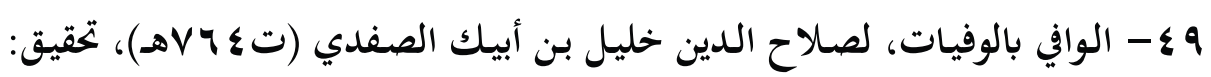

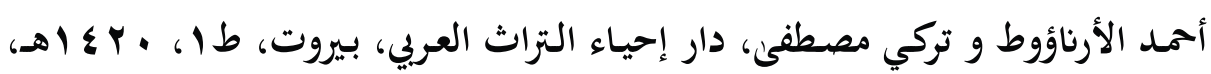

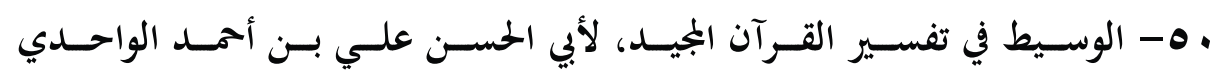

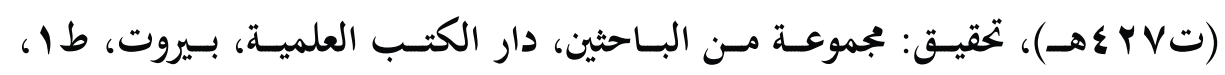

